


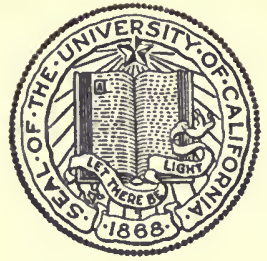

THE LIBRARY

OF

THE UNIVERSITY OF CALIFORNIA LOS ANGELES

\author{
Ex Libris
}

SIR MICHAEL SADLER

ACQUIRED 1948

WITH THE HELP OF ALUMNI OF THE SCHOOL OF EDUCATION 


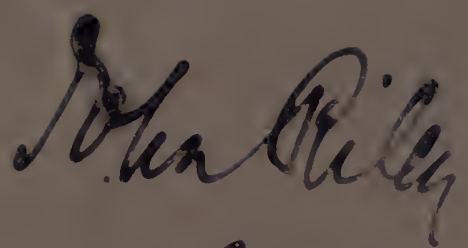

Cos. 15020 

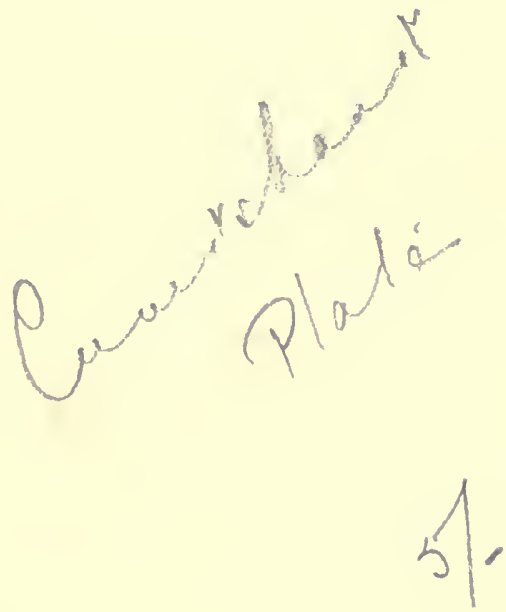

31

?2? 


\section{TA L P A}

OR THE

\section{Chronicles of a Clay Farm.}

An Agricultural Fragment.

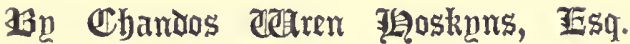

AUTHOR OF

"INQUIRY INTO THE HISTORY OF AGRICULTURE"

ETC.

Quid vetat?"

SIXTH EDITION.

LONDON :

LONGMANS, GREEN, A N C O. 1865 . 
LONDON

PRINTED BY SPOTIISWOODE AXD CO. YEW.STREET SQUARE 
TO THE

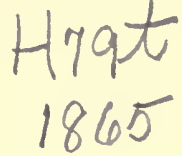

READERS AND CONTRIBUTORS

OF THE

'GARDENERS' CHRONICLE AND AGRICULTURAL GAZETTE

This Ge-Collection

OF SOME SCATTERED ESSAYS OF PAST YEARS

BASED ON THE HOPB AND BELIEF

NOT UNCONFIRMED AT THEIR HANDS

THAT AGRICCLTURAL THOUGHT MAY BE CANDID

AND EVEN 'SPECULATIVE'

YET HUSBANDRY NOT THE LESS PRACTICAL

IS FINALLY INSCRIBED BY

THE AUTHOR

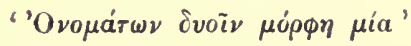


Digitized by the Internet Archive in 2007 with funding from Microsoft Corporation 


\section{CONTENTS.}

[first Srries.]

I.

THE WASTE

II.

THE DEVIL-ON-THREE-STICKS

III.

I PRICTICAL BEgLNNING .

IV.

I CONVERT,-AND A HERETIC .

v.

CONBNATION AND COMMLNTION

27

VI.

CALX-AND RECALCITRATION

FII.

EARTH-STOPPING

VIII.

' TRUTI AT THE BOTTOM OF A'-MARL-PIT . . . . 49 IX.

'FALLOWS'-AND WHAT FOLLOWS . . . . . 58

X.

THEORY AND PRACTICE . . . . . . . 67

XI.

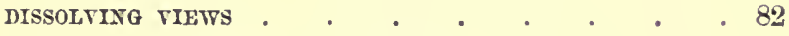

XII.

A WORD AT PARTING . . . . . . . 87 
[\$econd Seriss.]

XIII.

'FARM TO LET' . . . . . . . . . 99

XIT.

AN 'APPLICATION' . . . . . . . . 110

'LANDLORD AND TENANT' . . . . . . 120

XVI.

LOW PRICES AND LONG FACES .

. 129

XVII.

A 'JATUTTNAL HOUR' . . . . . . . . 142

XVIII.

'TALPA LOQUITUR' . . . . . . . . 153

XIX́.

THE ' POWERS' THAT BE . . . . . . . . . . . . . . .

XX.

'THE 'PLAIN ENgLisH' OF IT . . . . . . . 180

XXI.

THE STEAII-CULT YVATOR

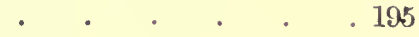

XXII.

THE SUBJECT CONTINUED .

XXIII.

SIACIITERY OF THE CLAYS

XXIV.

.206

CONCLUSION 


\title{
LIST OF VIGNETTES.
}

\author{
BY \\ GEORGE CRUIKSHANK.
}

PAGE

A Sketch-Introductory • • • . . . . 7

'Has it erer been tried with a Spirit-level?' . . . 12

-'As the weakest link of a chain is the measure of its strength'- . . . . . . . . . 19

'In spite of forty jears' experience to the contrary !' . 26

' Mingle, mingle, mingle,

Ye that mingle may!' . . . . 35

'A sort of jovial rebellion against the long despotism of Jack

Frost' • . . . . . . . . . 41

'Down went the Fences, notwithstanding' . . . 48

'The bright little sentinels of Hearen were taking one by

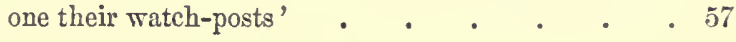

'The Wizard of the Pacific' • . . . . . 66

'I had the same profound respect for each and both' . 81

'Eheu! quantus equis, quantus erat viris Sudor!' • . . . . . . 86

' On through the silent night,-

While weary labourers sleep,-still works, alone' . 94 
'I say, Mr. Bowles, hare you seen this Farm that's advertised here?' . . . . . . . 109

- but the mischief lies in the corollary, - " so much for your Science!", . . . . . . . . 119

- In which there is at once Antagonism of interest yet Mutuality of object, . . . . . . 128

'All up with Farming, I doubt!' . . . . . . 141

'Indicating that which was, and is no longer" . $\quad .152$

' We shall learn of him another, and a greater lesson, some day, . . . . . . . . 166

"It's his first year at plough: he was "kipping craows" for the last two or three' . . . . . . . 179

- Steam-power,-no more to do with the Plough than a Horse has to do with a Spade' . . . . 194

'The willing giant stands idly panting and smoking' . 205

'Vestigia nulla retrorsum' . . . . . . 222

'Incontinently bent on their baptism of native mud' . 232

'The End' . . . . . . . . . 244 


\section{CHRONICLES OF A CLAY FARM.}

\section{[FIRST SERIES.]}

\section{I.}

THE WASTE.

$\mathrm{MuCH}$ as may be learnt, by a willing mind, from the wisdom of others, the most practical, and (shame upon us !) the most attractive lessons seem always to be derived from their failures. It is too late, in the natural history of the 'biped without feathers that laughs,' to stop and enquire into this little item from the list of his peculiarities; so I shall take it for granted in the most practical and amiable way in which it can be at once assumed and applied; and, like the self-devoted bird that plucks its own breast to feed the young brood, open up my early farming blunders to the instructive gaze of those young and ardent agriculturists who are just beginning to recognise the last of human Sciences in the first of human 
Arts, and to 'only wish, like duteous sons, their parents were more wise.'

I shall not tell when it was, nor where it was, nor why it was, that I first 'broke ground:' the first would be too cruel, the second too particular, and the third too personal. But I shall describe my Farm geologically, and myself categorically, which must answer every proper enquiry of the curious, and will leave a little untold besides, the better to keep alive the interest of the narrative.

Somewhere or other in England there is a flat bleak high-lying district, which a shallow or very terse geologist might haply describe as part of the New-red-sandstone formation; but where, if he would take the trouble to plough an acre, he would hear now and then a suspicious kind of sound from the share and coulter, which I may describe by the word 'soapy'; and where, whenever the nose of the plough chanced to dive an inch deeper than usual, he would see certain blue-looking indications turned up that would rather startle his complacency, if a lover of light soils, by a suggestion of the proximity of that terrible antagonist-the blue Lias. Should this discovery stimulate further exploration, and his plough be set a couple of inches deeper, his ears 
might presently be regaled with a sound as of a heavy-laden cart dragging over a newly-gravelled road, and after turning up a variety of conglomerates, as compacted as the bed of an old Roman causeway, and as many-coloured as Harlequin's coat, the stress of the pull would suddenly be eased, and the plough be heard swimming whisperingly through a bed of wet sand; and just as the filler-horse was congratulating himself that it was all plain sailing now, bang goes a trace or a spreader, and the plough comes to a standstill, just revealing, at the sharepoint, the bruised side of a quartz pebble as big as a foot-ball grinning at you from its tight nook in the bed of the furrow.

Have I described enough? or shall I add, to this subsoil sketch, a faint and feeble idea of the surface, some time about the month of February (surnamed ' fill-dyke' not without reason); and endeavour to paint the hopeless, currentless, resourceless, and pitiable condition of water, whose unhappy fate has fallen, or melted, upon fields as flat as a billiardtable, and without even a 'pocket' to run into f'or' escape or concealment? There it would stand, day after day, and week after week, and month after month, shining along the serpentine furrows, as if it 
never, never, never would go again! And the only wonder was, when or how, or by what bold amphibious bcing, the ridges had ever been raised, which it intersected, like a sample series of Dutch canals and embankments.

This was my farm: 250 statute acres!

'Why did you take it?'

I didn't. It took me. That ' mysterious lady' who is painted with a bandage on her eyes (she can see as well as you or I), made it, with a pat on the back, my property, and shortly afterwards, with a s!ap in the face, my 'occupation.' It had been performing for a series of years a sort of ' geometrical progression '-downwards. Each incoming tenant took it at about half the previous rent; dabbled about for a year or two like a duck, and retired'lame.' It was but a simple equation-a very simple one-to say when the rent would come to zero. It looked on the Rental-book like an annual sum in Reduction; 'facilis descensus Averni,' litcrally translated into plain English. What was to be done with it? This brings me to my proposition No. 2 : which is in fact what is commonly called ' No. 1'mysclf. If there was in the catalogue of human pursuits, one which I hated and feared, dreaded and despised, didn't know and didn't wish to know- 
it was that strange, incomprehensible, infatuated, damaging thing, which from my cradle upwards I had heard described and deprecated under the almost forbidden name of-Farming. Dr. Johnson calls it the delight of destiny to counterchange the plans and purposes of man; but some other wise man, I think it is Lord Bacon, tells us to ' choose the life that is most useful, and habit will make it the most agreeable.' But accident seems more potent than destiny, plan, purpose, choice, or habit. On a long sea-voyage, and in a rather resourceless foreign land, a couple of unbidden companions had stuck by me with persecuting tenacity, and attracted first my acquaintance, then my intimacy, for sheer want of anything else: they were two books: to wit, Cobbett's edition of Tull's Works, and the Useful Knowledge Society's volumes on British Husbandry. I read them, and re-read them; and then began again: for nine mortal months I was reduced to gorge my literary appetite upon these husks, as I at first regarded them. The Georgics of Virgil had begun and ended all my previous acquaintance with farming; they were the sole associating tie that connected me with this sudden and enforced onslaught upon the 'theory and practice of Agriculture;' and I returned to England-poor wretch-in worse 
condition than I went, - in fact, given up by the 'Faculty' as a confirmed-Book-farmer.

With this morbid predisposition upon meimagine me exposed unexpectedly to the fatal atmosphere of a sick-room in which lay a dying man, as he devoutly believed,-a land-stewardstricken with influenza, caught upon my marsh: imagine the reports, the lectures, the deathbed warnings $I$ had to sit and listen to, about this blessed farm! He described it as you would a pestilence; a terror to all around it; it must be cured, not for its own sake, but as you would treat a rotten sheep, or a truss of mouldy hay. It was Jainful, yet ludicrous, to hear him, for he talked like a dying man of a bad child-that would 'be sure to come to harm some day or other.' What on earth was to be done? Agriculture was not royal then-there was no 'Society's Journal,' no motto-laden buttons publishing the banns (for the first time) of 'Practice with Science,' no dear' little weekly bonnebouche of a Gazette, no July gathering of fat cattle and great men to look backward and forward to, during the other months. All was dull, blank, and cheerless, not to say 'flat and unprofitable.'

What was to be done? apostatise from all the pro- 
mises and vows made from my youth up, and take it in hand-that is, in a bailiff's hand, which certain foregone experiences had led me to conceive was of all things in the world the most out of hand, if that may be called so which empties the hand and the pocket too! Such seemed the only alternative : at first it was an impossibility - then an improbability, -and then-as the ear of bearded corn wins its forbidden way up the schoolboy's sleeve, and gains a point in advance by every effort to stop or expel it, sc did every determination, every reflection counteract the very purpose it was summoned to oppose; and, in short, one fine morning I almost jumped a yard backward at seeing-my own name on a wagon!

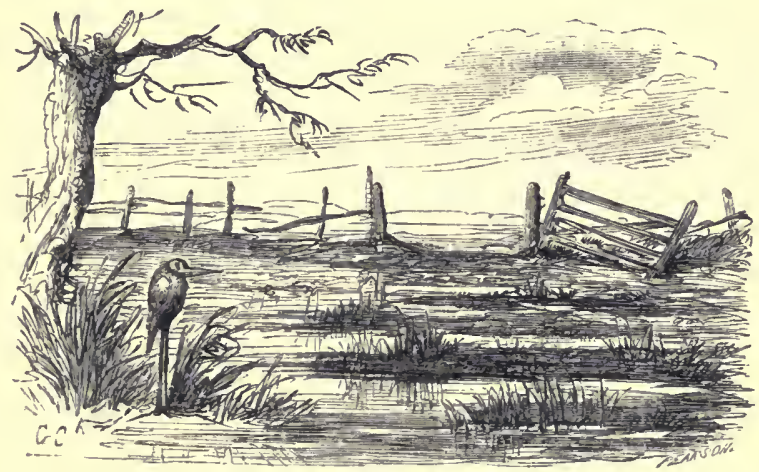

A Sketch-introductory. 
II.

THE 'DEVIL-ON-THREE-STICKS.'

There is an old saying that 'Fools build Houses for wise men to live in,' a proverb which, whether applicable or not to Farms as well as houses, probably receives about as fair an average of direct verification in the course of each man's individual experience, as any other of those mysterious marsels of traditional truth which are handed down from each generation to its successor, like faëry money, Gold in the giver's, Dust in the receiver's hand. The young experimentalist in brick-and-mortar, with a shake of the head not unworthy of the Elizabethan statesman whose posthumous fame has owed so much to that outward symptom of plethoric wisdom, sdmits the general and antecedent truth of the mottowhich might be scrolled up over so many a splendid doorway; he does not doubt or deny it, not he ! it is not to disprove its general, but to parry its paricular application that he purposes : it is not to invilidate 
the truth of the rule as against man, but to prove it by an exception, in the case of one individual of the species that he knows of. And the clear rectangular pencil-work and the softening shades of the brush of the accomplished artist-architect do their work upon his eyes, like Vanity reflected in a mirror, as he beholds (on pasteboard) the 'Splendid Elevation,' and then reads with delight in one corner of the sketch, the 'exceedingly moderate Estimate.' Such is ' the taper that has lighted fools,' each on his solitary track, out of the beaten high-road of old Experience, leading them on by the marsh-light hope of individual exemption from the Common Lot. And old men shake their heads, and only smile at the sallies of youthful arrogance that rise and break in succession upon the shore of life, and need no reproach but that which their own sure ebb will bring with it.

And so they felt, and so they looked on me, in the autumn of - no, I dare not say how long ago ! - when the arrival of load after load of Draining-tiles gave parish notice of the attempt to drain what Antiquity had pronounced undrainable, since the Deluge.

But why can't it be drained? asked Greenhorns. Because there's no Fall! replied collective Wisdon. 
Has it ever been tried with a Spirit-level ?

Now this was not a fair question. Spirit-levels (if they had any meaning or existence at all) were unintelligible mathematical-looking instruments of purely professional nature, only seen (if ever) in the hands of road-surveyors' assistants, and people of that sort. They had nothing whatever to do with farming. The question was unfair: it contained an ambiguous term.

Picture to yourself, however, the following conclusion from it. A bleak, foggy November day: a long rambling space, marsh or meadow, as you might choose to call it, of some twenty acres in extent, and about the third part of a mile in length, with a narrow, thick plantation of rushes, sedges, and brooklimc, and such aquatic vegetation, threading its way in onc long dank line from end to end, by such fantastic wanderings, that it looked as if the hidden channel of choked moisture it concealed had becn making a continued series of experiments from time out of mind in search of an outlet; and, after centuries of struggle and disappointment, had at length arrived, quite by accident, at a certain point of the mcadow, - where you might see a pair of high mud-boots standing, or rather soaking, with a man in them, peering through a telescope on three legs, 
as if he was watching for the total eclipse of a small boy that is to be seen-gradually sinking-about fifty yards off, and clutching in his agony a tall staff by his side, figured as if for high and low water mark.

Presently the Boots and the Telescope, after various ineffectual efforts and heavings, succeed in striking their quarters; the boy, after sundry spasmodic struggles, to correspond, achieves the same exploit; and the same scene as before occurs again some fifty yards further on, and again, and again, at the same intervals, until they reach the other end of the meadow, and come plump upon the banks of a marshy Pool some six acres in extent. On attaining this point, the telescope is suddenly shut up with a triumphant snap; its three legs jump into one; the dripping shivering boy receives a tremendous involuntary thwack on the back, and a Faul of Nine Feet is declared,-like a 'Dividend of ten per cent. and a Balance over to go on with!'

Oh, you primeval Carp, Pike, and Eels ! you little thought on that day how deadly a fishing-rod, marked and measured inch by inch, threw its shadow across your ancient domain; little did your believed security dream of so new a monster, the angler upon three 
legs, that had measured the altitude of your downfall, and caught you all, if not upon one, upon two cross hairs!

Old Fish or a New Farm? Snipes or Swedeturnips? Which was it to be? There stood but this question between the will and the way to let the Dry Land appear. And who knows what Saurian monstrosities of a primeval age might be brought into daylight when this stagnation of waters was let loose, which had dammed up the moisture of so many broad acres from time immemorial? since, little raised above the high-water mark of this pool, lay the subsoil of the whole farm beyond and around it; and the lowest point of this meadow was the lowest point of all.

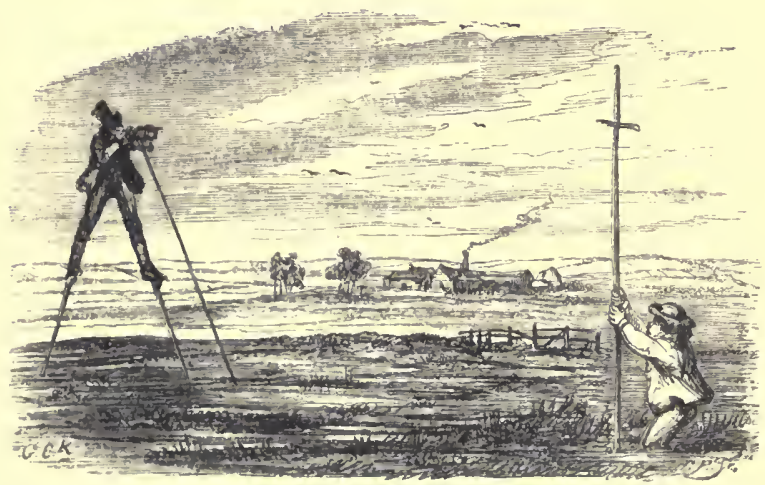

'Has it ever been tried with a Spirit-level ?' 


\section{III.}

\section{A 'PRACTICAL' BEGINNING.}

IT was urged by Mr. Brunel, as a justification for more attention and expense in laying the rails of the Great Western than had been ever thought of upon previously-constructed lines, that all the embankments, and cuttings, and earth-works, and stations, and law and parliamentary expenses,in fact, the whole of the outlay encountered in the formation of a Railway, had for its main and ultimate object a perfectly smooth and level LINE OF RAIL; that to turn stingy at this point, just when you had arrived at the great 'ultimatissimum' of the whole proceedings, viz. the Iron Wheel-track, was a sort of saving which evinced a want of perception of the true object of all the labour that had preceded it. It may seem curious to our experiences, in these days, that such a doctrine.could ever 
have needed to be enforced by argument; yet no one will deem it wonderful who has personally witnessed the unaccountable and ever new difficulty of getting proper attention paid to the levelling of the bottom of a drain, and the laying of the tiles in that continuous line, where one single depression or irregularity, by collecting the water at that spot year after year, tends towards the eventual stoppage of the whole drain, through two distinct causes, the softening of the foundation underneath, and the deposit of soil inside the tile from the water collected at the spot, and standing there after the rest has run off. Every depression, however slight, is constantly doing this mischief in every drain where the fall is but trifling; and if to the two consequences above mentioned, we may add the decomposition of the tile itself by the action of water long stagnant within it, we may deduce that every tile-drain laid with these imperfections in the finishing of the bottom, has a tendency towards obliteration, out of all reasonable proportion with that of a well-burnt tile laid on a perfectly even inclination, which, humanly speaking, may be called a permanent thing. An open ditch cut by the most skilful workman, in the Summer, affords 
the best illustration of this underground mischief. Nothing can look smoother and more even than the bottom, till that uncompromising test of accurate levels, the Water, makes its appearance: all on a sudden the whole scene is changed, the eyeaccredited level vanishes as if some earthquake had taken place: here there is a gravelly Scour along which the stream rushes in a thousand little angry-looking ripples; there it hangs, and looks as dull and heavy as if it had given up running at all, as a useless waste of energy; in another place, a few dead leaves or sticks, or a morsel of soil broken from the side, dams back the water for a considerable distance, occasioning a deposit of soil along the whole reach, greater in proportion to the quantity and the muddiness of the water detained. All this shows the paramount importance of perfect evenness in the bed on which the tiles are laid. The worst-laid tile is the measure of the goodness and permanence of the whole drain, just as the weakest link of a chain is the measure of its strength.

But this, of course, was all theory ; and theory, of course, was all nonsense: my practical head-drainer was quite of a different way of thinking, as his modus operandi will exhibit. The morning after he 
had commenced operations I found him hard at work cutting a drain about eighteen inches deep, laying in the tiles one by one, and filling in the earth over them as he went!

The field I had begun upon was large, and very flat; and in order to increase artificially the fall, I had calculated to make the drain eighteen inches deeper at the mouth than at the tail. I might as well have calculated for him the distance of a telescopic star.

'I've been a-draaning this forty year and more-I ought to know summut about it!'

Need I tell you who said this? or give you the whole of the colloquy to which it furnished the epilogue?

I had begun, something in this way- 'Why, my good friend! what on earth are you about? Didn't I tell you to lay the drain open from bottom to top, and that not a tile was to be put in till I had seen it, and tried the levels?' \&c. \&c.

Old as Adam-old as Adam was the whole dialogue--it is idle to go through it-Conceit versus Prejudice-the ignorance of the young against the ignorance of the old-the thing that has been, and will be, as long as 'the sun and the moon endureth.' It ended as I have said. 
'I've been a-draining this forty year and more I ought to know summut about it !'

Here was a staggerer. Amongst all my calculations to think that I should never have calculated on this ! I had seen the commander of a noble steamer with one parenthetical point of his forefinger (caught in an instant by the helmsman) put about a ship of a couple of thousand tons burden; I had seen the practical astronomer, with an infinitesimal touch of the directing screw of the telescope, bend his searching gaze millions of millions of miles away from its first position; I had seen the mill-owner, with half a nod to his foreman, stop in an instant the hurly-burly of a thousand wheels while he explained to me, in comparative quiet, some little matter of new invention in the carding of the rough wool, or the rounding and hardening of the finished Twist. I had seen enough of the empire of Mind over Matter in many forms and shapes, by sea and land, to make me the devoutest of believers in modern miracle. Under the quiet seductive brightness of the midnight lamp, I had revelled in the mysteries of Number and of Form; and in the working realities of daylight I had seen and stood witness to the application of those apparent mysteries to the most beautifully simple 
processes in the production of ordinary and universal articles of human want. It had furnished me no new or difficult gratification to level and calculate to an inch the amount of Fall to be obtained upon a field, which without this precaution might indeed be called, as it had been called, undrainable; and here I was fairly planted, at the first onset. Every inch of depth was of real value at the mouth of so long a line of drain. 'Three feet deep at the outlet' was the modest extent of my demand; and there I stood, watching the tiles thrown in pêle-mêle to a depth of eighteen inches, which I was given to understand was about 'two feet,' with as cool an indifference to the other foot, as if Two and Three had been recently determined by the common assent of mankind to mean the same thing.

'But I must have it three feet deep!'

'Oh, it's no use ; it'll never draan sa dip as that through this here clay!'

'But I tell you it must be! There can be no fall without it!'

' Well, I've been a-draining this forty year, and I ought to know summut about it.'

From that moment I date my experience in the 
trials and troubles of farming : at that instant my eyes began to open to the true meaning of those 'practical difficulties' which the uninitiated laugh at, because they have never encountered them; and which the man of science despises who has said to steam, water, and machinery, 'Do this, and they do it,' but has never known what it is to try and guide out of the old track, a mind that has run in the same rut ' this forty year' and more.'

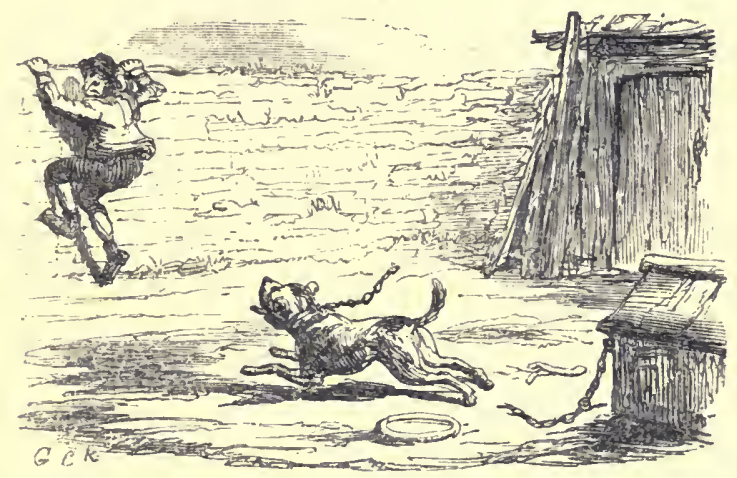

-'As the weakest lnk of a chain is the reeasure of its strength.'- 


\section{IV.}

\section{A CONVERT,-AND A HERETIC.}

WE have heard-and a little oftener than is pleasant-of victories gained in the field and lost in the Cabinet. The civil war that has waged so long between the partizans of the deep and of the shallow drain presents an experience the converse of this. Long after peace had been proclaimed-upon paper, -and most of the printed authorities had begun to pull together in favour of the deep drain-I say most, for even to this day a parting shot is now and then heard for the old system;-long after the shallow advocates had written themselves round to the other side, the battle was still waging fiercely outof-doors. Truly may the Draining-tile be said to have 'fought its way downwards inch by inch.' The benefit derived even from a drain eighteen or twenty inches deep under the furrow, which was still 
retained, was so manifest and immediate, that the very improvement itself prevented further improvement. A man who had shallow-drained one field, and found that even this did good, imagined himself furnished with a practical argument against deep draining, though he had never tried it; like those who condemn books they have never read, on the authority of opposite-thinking Reviews which they have read.

This was precisely the sort of reasoning that lay fast and strong in the skull of my old master-drainer; for master I saw he was determined to be. The evidence of a hundred Spirit-levels would have been no answer to 'forty years' experience' in draining and ditching. Of this I was quite sure : so we were at a dead pass. One or the other must give way 'and be for ever fallen.' It was easy to wish him forty years' more experience-elsewhere-and ' good morning'; but this would be only cutting the knot, and probably entailing another in succession. Nec deus intersit nisi dignus vindice nodus! He was a good workman, and his authority over his men not a thing that it would be wise to shake, even had that been possible. A thought occurred to me, a very bold thought, all things considered. I knew he hated the 
sight of the Level-that curious-looking thing on three sticks, - worse than the old gentleman that walks upon two. What if $\mathrm{I}$ could reconcile these two great opposing authorities by one timely stroke -make him Master-of-arts on the spot, before the eyes of all his men? Shorter and less earned degrees have been taken in the world. The opportunity was irresistible. I had it brought; adjusted it ; and told him to look through it and give me his opinion of the Fall. If you ever saw a dog put his nose to a wasp's nest, you may form some idea of the mistrustful curiosity and hesitating aversion with which he brought his face into close contact with his arch-enemy.

A long indescribable process ensued; a most determined effort to close the left eye with the right hand - then the right eye with the left hand--then a dead stillness, and a long fumbling breathless view of the world turned upside down, and his men standing on their heads for the first time, in spite of the forty year's' experience to the contrary ; and then-.

'Well I don't know but what you're right, Sir : the Fall does want a leetle easing at the bottom!'

The success was complete. In half an hour every tile was uncovered. The men worked as men work 
who feel justly proud of their commander: he had arrived at the highest summit of his profession. He returned to them with double authority and importance; and the drainage of my first field was soon accomplished: not as deeply indeed-as we now call deeply; but deep enough, after the ridges had been - twice cast, to allow Exall and Andrews' subsoiler to follow the cross-ploughing a year afterwards, and break to pieces as obdurate a hearthpan as ever resisted the root of an oak.

'After the ridges had been twice cast:' how easy it looks in print! What a pretty little Example-farm would England-and what would not Ireland be,if the Press could thus cultivate and civilise! -if ploughs were printers' types, and fields were paper -if bogs and fens and marshes could be drained like inkpots, and every drop that falls from Heavenfrom which there falls not one drop-No ! NOT ONE DROP - too much or too little-were apportioned to its proper place and task! It falls upon its proper place, and under that place lies its task, would but Man believe and act upon the hint, and do his part, his gloriously privileged part, in carrying out, for his own benefit, the purposes of perfect Wisdom,the indications of an ever-suggestive Handy-work. 
'After the ridges had been twice cast!' Why, those seven words that lie so smooth on paper, cost me three times seven months of single-handed fighting against the 'Experience' of a whole neighbourhood. No hawk in a rookery ever got better beleaguered. ' One down; t'other come on!' was the one perpetual motto of the daily tongue-task that awaited. me, fresh and fresh on every side, whichever way I turned. My own working-bailiff (et Tu Brute!) headed the attack within the camp-the traitor ! while a neighbouring clergyman led on the foe from without, evidently viewing the heresy in a serious light, and myself as a fit subject for an auto da fé. The conclusion of our last skirmish was too good to be lost to posterity. I entered it verbatim in $\mathrm{my}$ farm memoranda. Here it is.

' But tell me in earnest. Don't you mean to ridge up that field again?'

'No!'

"What, you mean to lay it flat?"

'Yes !'

'In the name of Goodness ! Why?'

'Because THE NAME OF Goodness - made it so!'

If I had suddenly assumed some demoniacal 
form, and then, leaving a train of smoke and brimstone, vanished with a clap of thunder from before the eyes of my catechist, I do not think his face would have assumed a greater expression of resourceless and complete astonishment than followed this extraordinary announcement of the reason for a farming operation. Vainly had I attempted to explain in former conversations that when a field is effectually drained, the furrows are inderground, three feet deep ; and that one of the great objects of breaking the subsoil is to enable the water to go where it was intended to go, DowrwaRDs; that every unevenness of the surface was a source of deviation, and therefore of unequal distribution, of that rich food which falls from Heaven,-Oxygen and Hydrogen,-commonly called WATER; that on the best land, farmed in the best way, furrows are avoided as a nuisance and a loss, except as a mark for measurework; and that the object of draining and subsoiling was-as the object of all Art is-to imitate NATURE in her most perfect examples.

The paradox of yesterday is the truism of to-day. Gas-lamps light up towns and Great Westerns cross the Atlantic, though Davy laughed at the one and Lardner at the other. And the principle of the 
Deep drain, which ten years ago the timid theorist dared not assert, for its wild and visionary seeming, is now the substance of the 'Report of a Committee,' the last tautology of admitted facts that men endure, and having consigned to the charnel-house of the Blue Books, inscribe its epitaph in an Act of Parliament.

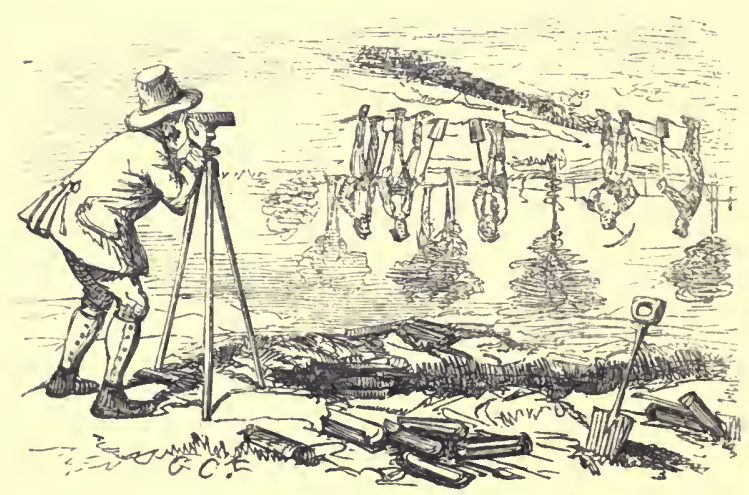

'In spite of forty years' experience to the contrary!' 


\section{V. \\ COMBINATION AND COMMINU'TION.}

There are some incidental points of practice attendant upon the drainage of a field, which give very little uneasiness to a beginner, but which, like many of the other realities of life, gain force with further experience. A blessed thing in its way is the untamed boldness of Youth. It gets done many things in this cautious calculating old world, which if not done then, would never be done at all, and which, whether useful for their striking goodness, or for their striking badness, afford equally profitable employment to that large and self-respected portion of the community whose business and pleasure lie in contentedly criticising the errors that others have made, in the charitable spirit of

'The fiend who never spoke before, But cries, "I warn'd you! " when the deed is o'er.' 
One of the points referred to, first presented itself to the notice of the Chronicler, in this wise :-

'A queer lot this, Sir!'

' Well, it is queer,' replied I, as the drainer threw out first a lump of blue clay, then a lump of red, then a horrible spadeful of white, then a dripping mass of yellow sand, then a kind of grey gravelly conglomerate, that had puzzled the very pickaxe whose delicate style of dissection had been brought to bear upon it, then a few spadefuls of beautifullyveined red marl, and then broke into a carboniferouslooking bed of black peat,- and then-but let the old drainer christen it, for my heterology is exhausted.

'A Queer Lot, this, Sir! What shall I do with it?'

I stood for a moment dramatically silent, working up my courage to a great effort. Out it came at last. - 'Let it be spread over the land!'

He was just raising his face to look up in mine. I knew what was coming; I caught one sight of his mouth screwing into an agony of contortion, as the idea loomed painfully, by degrees, upon his perceptions. I waited for no more, but turned quietly round, trying to stifle a fit of inward laughter-not at my own words, but at the effect I knew they were 
producing; and walked away. I turned once only, and saw him leaning on his spade, and looking after me. I can give you his soliloquy, for it was written upon his attitude, like the lettering of a picture.

- Well !-If that don't beat everything!'

A blessed thing, in its way, I say again, is the untamed boldness of youth. There was not a fullgrown ' practical farmer' within a ten-mile circuit of the spot where the old drainer stood on that day rapt in severe amazement, who would not have thought it as much as his fair fame was worth to give that order. Nothing but the inconceivable daring of pure unmitigated THEORY would have ventured its character upon such a throw. Now for the explanation.

Upon all wet thin cold clay soils, the wisdom of antiquity has long established that you are only to plough three or four inches deep; that you are to ridge up your lands into a certain round-backed shape which the rain may run off, as it would from an umbrella, or the roof of a house; that you are never to cross-plough, or otherwise disturb this consecrated form into which the earth's surface has been once-for-all moulded, but to keep scratching it, up and down, shallow enough to insure a seed-time by 
having a dry surface two inches deep, leaving the furrow, and about a yard on each side of it, as the perpetual channel or bed for water or ice in the winter, and baked sterility in the summer ; that if anybody dares to mention to you anything about that mysterious abomination called THE suBsorL, you are to screw up your mouth, shake your head, and say

'It won't do to bring up that nasty stuff!'

'But don't Gardeners do it sometimes?' I one day ventured to ask with child-like simplicity, in reply to the established doctrine.

' That's a different thing ; Gardener's aren't " practical farmers.",

'But don't THE roots of PLANTS GRow DownwArDs in a Field, as well as in a Garden?'

I don't know how it was, but that provoking question always brought the conversation to an abrupt close. I never could get beyond it. It stuck in my throat and everybody's else, like Macbeth's Amen. Left alone at last to my own ignorance, I dropped deeper and deeper, day after day, into a state of confirmed Theory. I got strange notions into my head, that, as two negatives make an affirmative, perhaps two bad soils might make one good one, and three 
bad soils a better still, and four bad ones the best of all! and when I saw the old drainer throwing out those lumps of many-coloured Clay, and Sand, and Gravel, and Peat, it was really too much for me. The monomania was irresistible: and the old fellow must have known it; for at the very moment when the paroxysm was at its height-just when the extravagant thought was flashing across me that though everybody declared nem. con. that it was bad, Some Ore had pronounced it Good-just at that very moment of weak hallucination, the old Lucifer, smacking his lips in an odd way of his own, looked up temptingly in my face, with his question, ' $\mathrm{A}$ queer lot, Sir! What shall I do with it?'

Blue and red, yellow and grey, white and black, stiff and loose, gritty and waxy, cohesive and repellent, soft and hard-there it lay before my eyes, my precious subsoil, in all its Protean variety of colour, texture, and consistency; there lay the rascally substratum that had pulled down strong men one after another who had tried to grow crops over it, exposed at last and brought to daylight like an unearthed fox; there it lay, dripping away its long pent-up moisture down the narrow channel that led to the newly opened outlet, through that 
same long meadow aforetime celebrated in this Chronicle; reminding one of a fallen foe bleeding out life and mischief at last and for ever. The impulse of pent-up theory was irresistible. 'Let it be spread over the land!'

And so it was. And a very curious-looking field it made for the livelong winter that ensued. Wise men came from all the quarters of the compass to look at it. Some of their remarks and questions were very flattering. ' Where had I purchased my Winter top-dressing? as they should like to buy some at the same shop, whatever the cost.' 'What winter crop was I growing so carefully under the variegated carpet?' 'Toall which I answered with becoming gravity, and modesty of my own merit. Some of the remarks being of a more mysterious character, I entered in my Farm Journal for future explanation and experience: such for instance as that of an old gentleman who, shutting one eye (I suppose it was a habit), told me with great blandness of manner, that I had 'put my foot in it.' (What could he mean?) Another was so full of general good wishes that he 'wished I might get it' more than once; which I thought all the more goodnatured as he did not even stay to particularise what 
crop he meant, or how much per acre. But of course I civilly 'wished him the same,' gently shutting one eye, as I saw it was the fashion, and had such a pleasing effect: at which, being an old friend, he performed the ceremony of inserting his second finger between the fourth and fifth rib of my left side, and informed me with a smile that 'he saw I understood chaff', to which innocently replying in the affirmative, I added, for reason, that I had $a$ great demand for it of late amongst my friends, and found it very useful in farming. Such are the dark and recondite passages presented by my journal of that winter, which I offer for the information and guidance of those who may purpose trying novel experiments unsanctioned by the established practice of their respective neighbourhoods ; merely noting that there are some things besides the soil, on this earth, which require a little tempering, and pay well to a man's peace of mind for being done quietly and neatly, without haste or heat,-yet smartly withal.

Spring came at last: beautiful Spring ! that fills the old heart with youth, and softens down to a more genial and hopeful tone the frosts and snows that reign within, as without, through dreary winter. 
Certain reports respecting the field that had been drained, and so curiously 'top-dressed,' had from time to time changed the current of opinion which had hitherto run so strongly all one way. The underwagoner had told somebody (in strict confidence) that the snow had disappeared on that field two days sooner than from any other. This had been repeated in equal confidence from mouth to mouth, with the addition that all the clay had ' kicked down to ashes;' but what topped everything was that before even Bean-sowing had begun, the 'Motley close' (so it has, ever since, been called) was reported ' as dry as a bone!'

The Harrow is certainly not the most ingenious or perfect of agricultural implements; but never was a more surprising feat performed by any, than was witnessed one fine morning early in March, when it was ordered over the field aforementioned! Down went the clay, sand, peat, and everything else,-
'Black spirits and white,
Blue spirits and grey,
Mingle, mingle, mingle,
Ye that mingle may!'

And 'mingle' in truth they did, into as free healthylooking a soil, as fresh and as mellow as if it had 
never lain underground or been out of the sunshine. With every turn of the horses, better and better it looked and worked. An increasing elasticity of movement seemed to pervade men, horses, harrows, soil, and even the very atmosphere of the field. Before the Work was half done, THEorY and The Chronicle were at a premium.

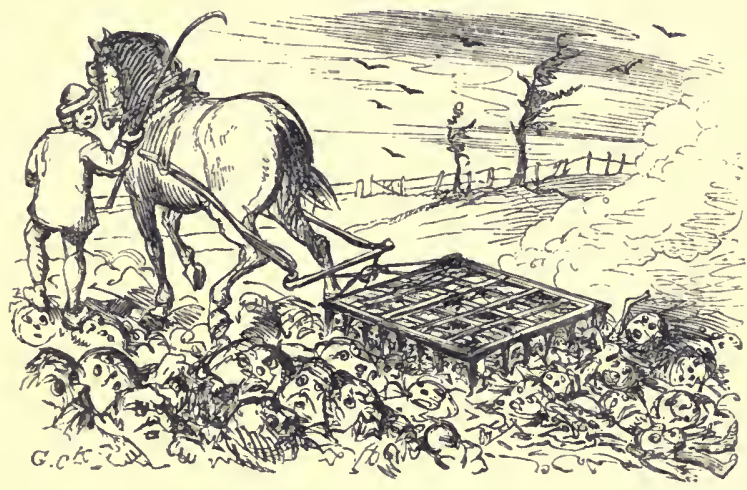

'Mingle, mingle, mingle, Ye that mingle may !' 


\section{VI.}

\section{'CALX'-AND RECALCITRATION.}

A LONG long time-what a dreary time-is Winter! Well may all Christendom have lent its comfortable efforts.through ages past, with a long and a strong pull and a pull all together, to give a point and a zest, and a time of almost legislative conviviality, in the Christmas fire-side and good fellowship, by way of in-door barricade, a sort of jovial rebellion, against the long despotism of Jack Frost ! It is hard to convey an adequate idea of the bounding pleasure with which-after watching, month after month unchanged, the rugged uncouth results of that novel piece of Autumn workmanship lately described-I saw at last the wholesome-looking combination of such a heterogeneous variety of earths that had lain icebound, as if for perpetual and stereotyped ugliness, now melting down under the genial influences of Spring, and that blessed pair of harrows, into what old Evelyn must have especially had in his eye when he talked of ' a roscid and fertile mould.'

' Easy work it is to preach about farming ex- 
periments,' thought I to myself, as I wandered, in the gloomy evenings of December and January, amongst the square clods that lay exhumed upon the surface of the field, with the spade-mark inscribed in frozen obduracy upon their sides, like the blocks in the quarries of Syracuse dated with the toolmarks of twenty centuries ago! ' Easy work to preach experiments, that take a year to make, and another to judge of, and another, and perhaps another still, to see the whole result of,--to men whose "threescore years and ten" were hardly a sufficient Lease in which to scrape together a dozen facts beyond what their fathers knew!' A pretty homily upon LEAsEs there lies in these clods that have been keeping sentry here these three months, while the Manufacturer has worn a steam-engine from new to old, and the Trader has turned over half his capital, and briskly put in a fresh stock of 'Spring Fashions.' In the name of Common Sense, that useful 'raw material' which England has as plentiful as Coal and Iron,-what dead carcase has been chained to this living Art of Arts to clog its progress and to rot its vital powers, by adding the curse of INsecurity of Tenure to its already arduous and time-and-patience-needing problems: If it be Mind that acts upon Matter, what is it that 
acts upon Mind? Surely Motive and Interest, and that Assurance of Results, which the most ordinary prudence demands, and the most buoyant energy feeds upon-or dies.

Well may a bold experiment startle minds which have been drilled into the habit, because into the necessity, of contracting every prospect, every outlay, every mental conception, within the compass of an 'Agreement for a year!' If there is an attribute which more than others marks the distinction of the human mind from that of the lower animal creation, it is that it looks forward: if there is an art that more than others demands the powerful and prolonged exercise of this faculty, it is agriculture: if there is a thing which adds force and method and precision to this faculty, it is- $E d u-$ ration. Does the pen need to draw the conclusion? Can the reader of 'Sermons in Stones' decipher no Lecases in Clods, no Schools of practical instruction in 'Calx, Silex, and Alumen?'

Winter, however, like Adversity, has a surprisingly improving influence upon —— things made of Clay. As each little thaw, towards spring-time, came and went, the gradual process of granulation had broken down the once wet and reeking spadefuls into the form of dry loose Mole- 
heaps. As the tines of the harrow jumped and danced freely through the mingling mass, what a changed appearance was left behind! a dry rich earthy scent, sweeter than the breath of an Orangegrove, or the evening incense of the hay-field, rose gratefully up to meet the fresh morning beams that shot their influence for the first time on the new face of an old field; the busy gossamer drew its glittering net-work from point to point in a thousand geometrical forms over the levelled surface.

- Well! I never thought to see it look like this ! I should think anything 'ud grow here!'

Such was the remark I overheard. I suppose it came from one of the horses; they were the only living things present that were not pledged to an opposite opinion. The observation, however, if illfitting, was not ill-timed: it chimed in with the thoughts that were tumbling over each other in theoretical confusion through the brain of the incurable Chronicler. What would have been thought of him had he dared to utter them aloud, as they came and went in this strange fashion-

- The protoxide into the Peroxide! ha! a 'beautiful change that. Clay, Sand, Peat,-and 'Marl too! a goodly compound. How is it that a ' sort of instinct seems to anticipate the conclusions 
' of Science-that the mind outstrips the page, and 'one's assent to each proposition seems paid in 'advance, before it falls strictly due? Is science 'intuitive? then why is it MODERN? Why have 'centuries upon centuries-sixty centuries-passed, ' and none till sow? Why now? Could Liebig 'answer that? I'm afraid even his "Quantitative "Analysis," his grand discovery (for so it almost 'seems) of the magic residing in those words, " " Numero, Pondere, et Mensurâ," would be baffled ' to resolve that problem.

' This field for instance! they never thought to see ' it look like this: now, could they answer the 'question-What does it yet want?-Yes! the "instantaneous reply would be LIMe. "Why?" "inquires Theory; "Because it would sweeten it"'would be the answer. But wHY? Theory again 'asks. Practice is silent. What? silent, after "sixty centuries of "Experience!" Can nobody ' give us an answer-the truth, and the whole truth 'of the operation of Lime upon soils?' The Chemist attempts an explanation.

' Its effect arises from its avidity for combination; ' it searches out free acids, as a ferret does a rat, and ' instantly closes with them. Sulphuric, phosphoric, ' silicic, nitric, humic, and last not least, the "Great 
"Dissolver," Carbonic acid: all these it makes "known, by seizing upon them and becoming their 'base; thus disintegrating as it were, and recon'structing the elements of the soil, and exciting to 'a new action the sluggards of Nature wherever ' they are lurking.- - It is the Composer' and the De' composer, for nature cannot suffer either process, 'but fertility must follow : re-composition (growth) ' has begun ere decomposition is over: does a latent ' atom of organic matter stand inert for one instant? 'it is at him, like a Policeman,_- "Come, kip 'moovin!"'

But is this all ?-is this half?

Well may the 'Incoming Tenant' ask ' How far is it to the Lime-kiln?'

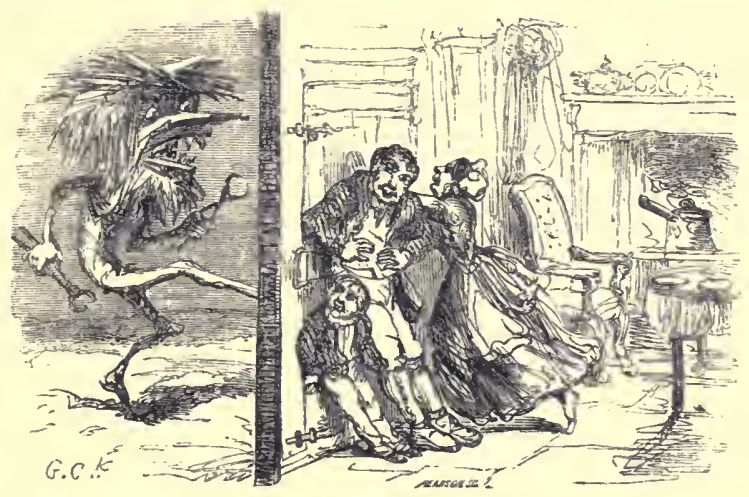

'A sort of jovial rebellion against the long despotisn of Jack Frost.' 


\section{VII.}

\section{'EARTH'-STOPPING.}

Amongst the various changes upon the aspect of a Farm necessitated by modern practice, there is none which causes a greater degree of consternation in the immediate vicinity than the removal of the Hedgerows. There is a kind of time-honoured recognition and respect accorded to these huge ' mounds' four or five feet high, and broad in proportion, with the running accompaniment of jungle sprawling at its pleasure in the plough-land alongside, which it goes to the very heart of the labourer's themselves to desecrate, or reduce to the regulationstandard. It is all very well under the glowing candie-light, with the map of your farm spread out before you, and its hedgerows reduced to mere lines of sepia or lamp-black, to cut and carve, at your will, ten or twelve large square comely-looking fields out of thirty or forty unaccountably-shaped rhomboids undreamt of in the hardest book of 
Euclid, and then to go and dream the realization of your symmetrical example-farm, the wonder and delight of ardent agriculturists : but what a change comes over the spirit of the dream, when you mizzle out $o^{\prime}$ doors in the foggy November morning, and come to a dead stand-still at the tangled side of a fence (Bless me! why it looked nothing on paper!) which has furnished the talk of many a Hunt-dinner for some centuries past, for the splendid leaps and the splendid 'purls' it has given rise-or given fall to. Its height-its enormous width-its insurmountable impracticable look altogether, require an eye quite as steady and a heart quite as firm as the hunter's, to take it.

It seemed like sacrilege,-indeed I felt selfconvicted, at the first daring onslaught upon these giants of the olden time. I was obliged to 'take a run at it' mentally, as it were, as many a man and horse had before done bodily and in the flesh; and stuff my ears against the covered reproaches of the workmen.

'Famous bank for rabbits, this here, sir? I've know'd twenty couple killed in a day out of it, in my time, when Squire_-_.'

'Ah! well-never mind'-quoth I, sorely and 
interruptingly: 'but what's that-what have you got there?"

'This, sir? Lor' blesh ye! this is the earth where that ould vixen lived as gave you such a run last winter: I've know'd a litter o' seven whelps reared in this hole, an' heerd 'em a yelping an' howling o' the summer evenings as if the' wondered when upon airth cub 'unting 'ould begin!'

This was the climax, usually. No martyr ever suffered more than I used to carry home to breakfast imo sub pectore, by way of travesty to my over-night's imaginative enjoyment at the paperprospect of large enclosures and unimpeded ploughshares.

But the day of compensation came at last; and with it came my first discovery of the extraordinary sheep-sightedness of spade-and-mattockwielding humanity. Not till the fence was clear away, bank, thorns, pollards, ash-trees, rabbit-holes, fox-earths, and all, did I ever hear the exclamation-

' Well! this is a wonderful alteration, to be sure; why, I never thought to see it look in this way! It's quite a beautiful field now !'

' One cheer for THE MAP after all!' quoth I to myself, as at next candle-light down I sat again 
over the bird's-eye view of acres which I now began to find were trodden by bipeds and quadrupeds with about equal perception of their plan and bearing. Who would be without an accurate Map of his farm, who once knew the cumulative triumphs that it brings of skill and head-craft, as lavishly accorded in the end, as denied in the outset, by the gregarious juries who sit in judgment on his acts?

Down went fence after fence! each with precisely the same prologue and epilogue of blame and praise: for, all the successful issues in the world never stop or stay that rampant 'inconvertible' thing, criticism; that battery of pop-guns that is never silenced or taken by assault. Down, however, went the fences notwithstanding: and certainly, without reference to any of the more subterraneous improvements of drainage, cultivation, or otherwise, the mere accession of business-like appearance to the farm, when denuded of its miles of jungle, was, as Dame Quickly says, 'a thing to thank God upon.'

It would be a difficult but interesting task to make out a calculation of the economy per acre, of the riddance of these hideous and useless strongholds of roots, weeds, birds, and vermin that afflict the farms 
of merry England. Unproductive in themselves of anything that is good-for even the timber they contain is but rarely so-they are equally an obstruction to the plough that toils for bread, and the eye that wanders for beauty. Far be it from the old Chronicler to depreciate the 'tangled copse' or the 'boundless contiguity of shade' that gilds the early remembrance of some, and the imagination of all; that lives in the tasteful pages of Evelyn and Price, or in the 'charming bits' of Wilson or Nasmyth: but where can be the pictorial or moral beauty of a great crooked artificial mound surmounted by a dead fence serrated into gaps and 'raspers,' or at the best, hogged into dreary uniformity that cuts the blessed landscape from the eye, by a man-made barrier of stakes and 'witherings?' 'Take away the curtain that I may see the picture' might any mortal say, who from his first lesson in Geography had learnt that a man six feet high has a sort of physical right to a panoramic horizon of three miles on this round globe of ours, even in a district like mine where not a hill was to be viewed.

To be sure there is one rather formidable consideration-the hedge-pheasant-shooting-' beating the outsides '- that pleasant October skirmishing that precedes the coming up of the heavy artillery at 
Christmas; but is it not rather dearly retained, when land is being cut up for Railroads all round us, at two or three hundred pounds the acre, and scarcely a vestige or margin left to inclose for the ' more more' cry of an increasing population?

It is at the least a consolation to think that these huge banks have no prescriptive right: that when Cowper told us 'Grod made the country,' he did not mean to deny that man made the hedgerows, or the conclusion that what he had raised up, he might pull down; especially when it is discovered, as each may prove for himself, that the Thorn grows best upon the level.

No! let the Park and the Pleasaunce have their varied and picturesque alternation of bush and tree and green-sward, of broken masses, winding glades and labyrinthine glens; and let the forest have its leafy screen, its deep and devious mysteries of light and shade; but let the field of the husbandman have that beauty of its own-the charm that Nature delights to throw over everything in proper turn and place. The waving and extensive Corn-field, the deep rich winter verdure of the turnip-crop, the dark and mellow surface of the fallow, owe little of beauty to the net-work of intersecting barriers that arrest at once the plough and the prospect, and carry 
a running nest of robbers, like earthworks of the enemy, through the fair fields of human skill and labour, and sacrifice at once the food of man and the profit of the grower.

It is the eye of Prejudice, not of Taste, that sees Beauty absent from Utility. Even in the flattest districts, even upon 'the Clay Farm' itself, there is an undulating outline, a morsel of the varied profile of our mother earth which never revealed itself to the eye until those impediments were abolished, which-like Ignorance-make us mistake for a dull straight line that which is only a part of THE GrEAT Circle.

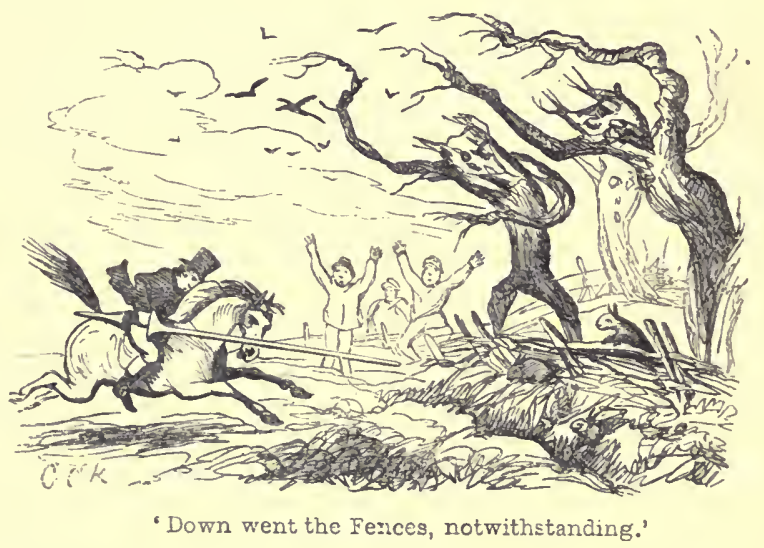




\section{VIII.}

'TRUTH AT THE BOTTOM OF A'-MARL-PIT.

Arongst the legacies which the wisdom and labours of antiquity had bequeathed to the Clay Farm and its cultivators, one of the most curious and truly puzzling was a quantity of Marl-pits. In every field of five or six acres there was a great yawning ' Pit,' deep enough to drown the weathercock on a church steeple, and wide enough to accommodate the church as well; and when the broad hedgerows were stocked away (and, in good truth, my two first winters made strange havoc amongst those mounds of aggravating width and crookedness), nothing can be imagined more absurd than the effect of these deep wounds disclosed upon the bosom of mother earth, lying thick and threefold in the fields as now enlarged to an average of about twenty acres each. What on earth-or rather under the earth-was to be done with them? Favoured occupiers of the valleys and 
meadow-lands of our Island, you hardly know what I mean ! lend me your attention for a moment, while I read a short chapter from that Geological Economy which experience and the clays have taught me.

Amongst the manifold varieties which Nature offers to the mind and gratitude of man, not the least beneficent and beautiful is the Undulation of the earth's surface. How little do we value gifts and blessings that are quite familiar! Imagine for a moment a fiat earth with no variety - no inclination of outline; no hills, no dales, no uplands or meadows, no running streams or rivers, no tufted knolls or winding dells, no 'gradients,'-but one vast unruffled surface, like the sea in a dead calm, or the Great Desert itself: and then imagine one thing more, a thing which you are in the conventional habit of considering one of the greatest of agricultural blessings-a free percolating subsoil, underneath this vast monotony of surface, sucking down every drop of rain as it falls, and preserving not the value of an eggshell of liquid for man or beast to slake his thirst withal. What would you have given, under such a state of things, for Two Hundred and Fifty acres of CLAY SUBSOIL? Would you not have regarded such a means of retaining some of the moisture given 
'TRUTH AT THE BOTTOM OF A'-MARL-PIT. 51

by the clouds, almost as a special providence ?* Too much water-too much anything, however good-is always an inconvenience: but which were best- too much, or none at all? Now this is precisely the thought that used to occur to me (marked ' private') whenever some visitatorial geological new-and-improved-agricultural stranger bestowed an overdose of sublime pity upon the affliction of clay that lay underneath my Flat Farm.

' A pretty business you would have made of it,' I used to think, as I heard them glorifying the merits of a free subsoil - ' if you had had the ordering of it !' Heaven be thanked, a Wiser Hand than yours has had the management of these things, and has, for the most part, confined the sandy subsoils to the neighbourhood of rivers and running streams. Put yourself on the top of a Salisbury coach, some fine, hot midsummer's day, and take a trip across the Marl-

* 'Levelled of Alps and Andes, without its Valleys and Ravines,

How dull the face of earth, unfeatured of both beauty and utility!-

Praise God, creature of earth, for the mercies linked with secrecy :

Praise God, his hosts on high, for the mysteries that make all joy.'

['Proverbial Philosophy.'] 
borough downs, and then you will see what it is to have a thirsty chalk subsoil upon high land, 'where no water is:' and then you will see reason to conclude that there may be some problems even more puzzling to deal with, amidst the infinite variety of earth's surface, than a clay subsoil.

As late as the middle of the fifteenth century,we are told by an old writer* on husbandry matters, - Lime, even close to the kiln, was dearer than Oats ;' an odd comparison, yet forcible too; and as roads were not then exactly what they are now, it is easy to see that our forefathers had reason good for making the Marl-pit to do duty for the Limekiln. $\dagger$ The inorganic matter that was jogged away from the Farm with every bushel of wheat or pound of butter or cheese that went to market, did not come back again from the clouds. They soon found out that. Human instinct and experience had discovered the gradual loss of something, which neither

* Whitaker, Hist. of Craven, p. 324.

†It is worth remark that Sir Anthony Fitzherbert, Chief Justice of the Common Pleas, (whom by the bye I hardly deserve to quote, seeing he calls himself ' an experyenced farmer of more than 40 yeares,') in his 'Boke of Husbandrie,' published in 1523, frequently mentions the employment of Marl, but in his list of manures, etc., omits Lime altogether. 
' TRUTH AT THE BOTTOM OF A'- MARL-PIT. 53

rain nor sunshine nor even the farm-made-manure, deprived of these elements, could restore,-long before Davy and Liebig were born, or Sulphates and Phosphates had been christened: and hence the Marl-pits.

Curious and awkward relics of a bygone day they were, dotted about over my farm, and looking more numerous and unmeaning than ever, after the enlargement of the fields, and the straightening of the few fences that were left. Load after load of clay from the drains, and some hundred butts of felled trees, and useless pollards from the vanished hedgerows, were cast headlong into their voracious depths : but enough yet remained, and will long remain, to tell of the enormous labour that must once have been expended in excavating a manure more costly in its application than the Guano which from the far islands of the Pacific Ocean, conveyed by sea and land, thousand upon thousand of miles, finds its destination at last upon the field of British husbandry.

Well might the farmer of the olden time bore like a Well-sinker, at whatever amount of labour, for aught in the shape of a restorative, when 'the difficulty of communication arising from the nearly total want of roads precluded the interchange of commo- 
dities; when goods were carried on pack-horses, a mode of conveyance which necessarily prevented the conveyance of bulky articles to any considerable distance. The price of grain was thus materially affected, for while some districts were suffering from scarcity, others were overflowing with a surplus, and it was enhanced beyond its real value in one place, while it sunk below it in another: just as at the present day, in many parts of Poland that are distant from great towns, and without water communication, the value of the crops is so diminished by the expense or impracticability of carriage on ill-constructed roads, that cultivation is generally neglected.*

In a word, cheap labour and dear carriage were the tools that dug those ancient marl-pits; and many a long and lonely reverie upon the changes that centuries have brought about, did they afford me,after the last workman had whistled his willing way homewards, and I stood upon their brink with the silenced field around me, and the evening sky drawing its noiseless curtain overhead; till some peeping twinkling spangle, reflected in the water at my feet,

* Introduction to British Agriculture. U.K.S. 
warned me that the bright little sentinels of Heaven were taking one by one their watch-posts, and beckoning me to follow the example which one weary toiler after another had set, ${ }^{*}$ even to the very Plough that lay sleeping in its bed in the halffinished furrow at my side, as if nothing would ever move it again. And then through the still night air, as I moved tardily homewards, there would come a sound-a strange sound which the diggers of those ancient marl-pits never heard by day or night. Was it a beetle or some other lazy insect, homeward bound, that made that peculiar humm which seemed to thrill through the atmosphere, far away at firstthen gradually nearer, and then louder and more tremulous as a gust of wind brushed by - then fainter -and fainter still-and then-gone! What was it? if the ear could measure miles, it might seem to have traversed some seven or eight, before it reached me. Oh! ye who tilled these fields and dug these marlpits in the days of narrow lanes and pack-saddles, what would you have said to that Mail-Train that was flying like a meteor through the night, upon its track of polished iron; annihilating Distaxce, yet

$$
\text { 'et jam nox humida cœlo }
$$

Præcipitat, suadentque cadentia sidera somnos.' 
leaving SPACE undiminished; turning the wide-spread ountry abodes of men into one vast Metropolis of human Society, Mutuality, and Intelligence, not choked and deadened by long rows of brick-andmortar, like the dull changeless man-manufactured Town, but open and free and independent as ever, with earth and air and sky unpolluted, undesecrated by the Throng ; yet Man united by the closest intercourse and sympathy with the marts of aggregated skill and progress in each Art and Science that instructs, enriches, or ennobles.

Despise not the Town, O man of gaiters, corduroys, and short-cut-away, whose face is stereotyped into perpetual jollity by Nature's merry wholesome hand, whose talk is of Swedes, Superphosphate, and Red Lammas; nor do thou despise the country, $\mathrm{O}$ frockcoated, sleek-hatted, umbrella'd Town-denizen, whose face is blanched and thoughtful, and mayhap a little wrinkled, and whose talk is of Price-current, Scrip, Cargoes, and Consols. For you are each other's Customers and Brothers; the iron artery of locomotive traffic, and the electric nerve of flying Thought, have brought you into a new and closer bond of reciprocity and fellowship: it matters little at which end of the wire your place and life-task are ap- 
' TRUTH AT THE BOTTOM OF A'-MARL-PIT. 57 pointed; your hearts and heads were cast in the same human mould, and it is hard but such a tie as now unites their throbs and thoughts, shall strike out some results and combinations that you scarcely dream of yet, from the twin realities of Agriculture and Commerce.

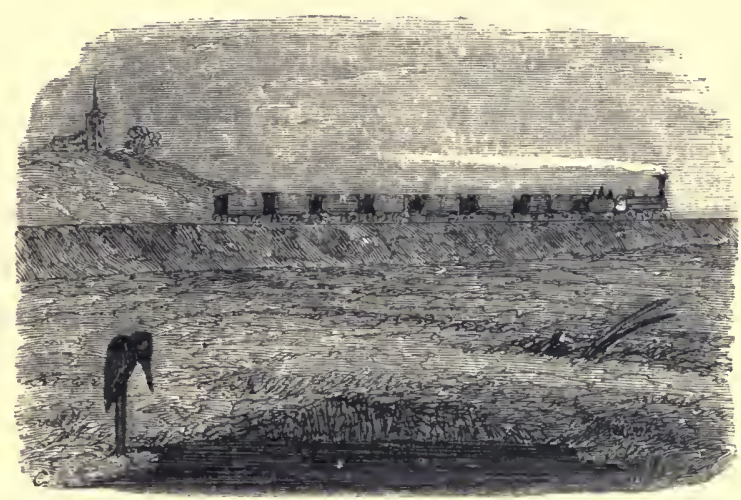

'The bright little sentinels of Heaven were taking one by one their watch posts.' 


\section{IX.}

'FALLOWS'-AND WHAT FOLLOWS.

WHen the land is drained, and the crooked ridges obliterated; the useless fences stocked away, and the few that remain straightened; the Ash-trees and old pollards grubbed up, the awkward inequalities of surface reduced, by the spade as well as the plough; the Farm-buildings improved, and adapted for the better and roomier accommodation of a better and larger head of stock: and last, not least, the House rendered habitable for human beings ' both male and female' -when all this is done-and thanks to increasing Population, increasing Trade, and increasing Intelligence, such things are done, here and there, now-adays; - it will in most cases be found that a considerable amount of Time, and of-something else will have been expended. But can it in truth be said that until this be done, the Plough can ever start, with a fair chance? Does any one seriously believe that the employment of his farm-labourers 
for a few winters, in the execution (as much as possible by fairly-paid task-work) of these preliminaries, is a matter of supererogation or an unprofitable outlay? Suppose it cost 10l. to the acre, and, including all, we must prepare for such an average, is it so extravagantly disproportionate to the looked-for return in the shape of Interest for Capital as to exceed the ordinary ventures of men in other branches of industry? Is the abolition of the bare summer Fallow, of the half cultivated and therefore half productive Headlands, of the eternal labour of hedging and ditching, the depredations of birds and vermin, the everlasting turning of the plough and other implements of culture, with time-losing, harnessbreaking, and horse-laming, to correspond; the injurious shade and droppings of trees, the stagnant water, and the barren furrows, - is the immunity, I say, from all these and many other evils recurring not once, but every mortal year, and year after year, to the end of time,- - to be foregone, because of the dreaded outlay (and is it a loss of the interest?) of $10 l$. per statute acre?

The question seems simple enough : yet after all is done, whether by Landlord or Tenant, or by both in one, there is yet one more question to be asked 
before the answer can be prudently ventured. I do not mean the question whether there is a long Lease: that indeed must speak for itself: it is a question if possible more important than even that. It is a practical question; let us give it a practical elucidation.

It is one of the most expressive and meaning features, rather than a deformity, of agriculture, that it is full of exceptions and variations, and of what men call Disappointments. However good in their way broad principles and laid-down courses of cropping or of treatment may be, experience soon teaches us that not only each soil, but to a certain extent each field, has its own independent character and claim upon the judgment, which will not be wisely submitted to the Procrustean law of this or that succession of crops. Skilful management is at least required to coax a farm into the designed and fore-determined Rotation of four-course or six-course, or any other course of husbandry; and to this end it is generally useful, and sometimes amusing, to inquire into the local reputation which almost every field will be found, on inquiry, to have established. But when two or three or four fields come to be thrown into one, in a district originally close-fenced, and where great varieties of soil are met with, this 
deference to the archcology of the land becomes rather puzzling to indulge and carry out.

Being bent upon the adoption, as far as possible, of the six-course shift, I had made it one of the occupations of those valuable provisions of nature, - the long Winter Evenings, - to cut, carve, and contrive, upon the map of my farm, a division of the arable land into six principal fields. The task was not a very easy one. The inclination of the land, being very slight, had to be studied with the greater care; the fences that should remain were not always the best or the straightest; and that half-way house of indecision (so well known to all busy travellers on the highway of life), between making a good job at once, on the one side, and economy of labour, on the other, occasioned many a halting hour of doubt, during which Day and Night, Map and Land, alternately gave each other the lie, and took it back again, with that quick reciprocity and alternation, for whichlialf-way houses, real as well as metaphorical, are not uncelebrated in fact and fiction. We are told by the oldest of profane historians, that it was the practice of the ancient Persians to think over every important plan twice: first, in the morning when they were sober, and again in the evening 
when they were-making speeches; and vice vers $\hat{a}$ : and as decision and steady purpose, in the field, when the work is once begun, is as useful, and almost as necessary, to the Farmer, as to the Field-marshal; and as that exacting and important branch of the conmunity-your neighbours-don't usually approve of your doings until they understand them-or in other words, laugh at you, till you begin (or might begin) to laugh at them; it is eminently advisable, at least I found it so, to call a pretty frequent meeting of that privy-council which every man is Chairman of, who has got Daylight and Eyes, Candlelight and Brains, a Farm and a good Map of it. And if, $\mathrm{O}$ ardent and yet perhaps sensitive Beginner, you will take one word of advice from an 'old file'-if once you have come to a determined vote and conclusion, after full deliberation with these fellow-councillors, and after hearing all they have got to urge pro and con.,-don't let anything or anybody divert or modify your plan. Your experience and mine will differ very much if you do not find more expense and more regret left behind invariably by an under-done than by an over-done job. 'The first expense is the least' in agriculture-and in every thing else perhaps, with the old exceptions of Law and Matrimony. 
The first field which I had drained, and to whose chronicled history I must now return, was a tolerably rectangular result of what had formerly been two fields, and part of a third; and consisted, after its enlargement, of about twenty-two acres. One half of this, that is to say, one of the fields as previously fenced, I devoted to a crop of Swedes-the first that ever had been heard of on the farm (and the last, in the opinion of all surrounding Wisdom, that ever would be); the other part, for reasons in which I suspect you would have acquiesced, had you seen it, I determined to indulge with its old but longforgotten friend, a bare summer fallow, and with a dose of that same Lime, about whose chemical effects and influences we had so long a soliloquy some time back. Until the end of April all went on alike over the whole of the twenty-two acres. Ploughing, scuffling, and levelling were the order of the day; but on the ponderous and august entry of the clod-crusher (a new monster in those days), the first-mentioned half of the field took leave of the other, and as each clod yielded up its individuality under the potent arguments of that most persuasive of implements, the modern fallow went a-head of the ancient, and old Jethro Tull himself 
would have envied me the delight of seeing the work of comminution and perfect intermixture which its magic transit left behind it. Never was there such a sagacious or relentless old tyrant in dealing with a clod, as this same Crosskill, for so it shall be named, and right deservedly. If he can't crush it with his elephant foot, he takes it up secundum artern as a mastiff would a bone, and gives it a squeeze with his iron teeth; and if that won't do, why then like a bull he tosses it over, and gores it with the next revolution. Clever must be the lump that, after one or two such embraces, escapes with its integrity less broken than to the exemplar of a handful of Walnuts.

Then came a nameless implement of private use and manufacture-a mysterious compound breed, with a grubber for its sire, and an iron hay-rake for its dam, to lift and re-expose the crushed and stifled soil; and then the large and heavy roller to crack the walnuts; and then-

(Even in the most fertile districts the Straw crop had been short the previous year: the manure was therefore small in bulk, and the quality, on a farm that had never borne a Turnip-!)

' Shall we begin the ridging up for the Swedes to-morrow?' quoth the bailiff. 
' Yes, one half of it; the other half will be manured with guano.'

'With what, Sir!'

I will spare you the little scene of utter mystification which followed this announcement; the subject is antiquated now; though many an amusing tale might doubtless be told of the first introduction of that 'magic compound' upon the rural mind. In spite of smiles, winks, murmurings, shakes of the foreboding head, and other demonstrations, jocular and serious, the guano was at last duly sown, on the flat, a ton to five acres, and ridged in; the other five receiving a hundred cartloads of 'the good old stuff', hauled (half a mile) from the farmyard, forked into the ridges, and covered in by a second ridging, as usual.

'A hundred to one upon the farm-yard manure!' of course-or any other amount of odds : all bidders, and only one moonstruck, misguided taker. It proved a miserable year for Turnips generally. Everywhere 'The Fly' was omnipotent and omnivorant : the odds fell a little when the highly backed 'farm-yard' ridges had to be sown a second time, but a crop came at last,- - about the size of apples.

And what on the guano? 
From twenty to twenty-four tons, by weight, per acre. Not 'the best' but 'the only' crop to be seen in the neighbourhood.

If people sometimes get less credit than their due in this world, they must not forget to balance the account with that which they get without deserving.

The Penguin of the vast Pacific was the Wizard that had made this crop, not I: yet had good Sir Matthew Hale been living, not all the waters of the Pacific would have saved me from roasting alive.

So much for ten acres out of the twenty-two, and the modern fallow : now for ancient practice, and the other twelve.

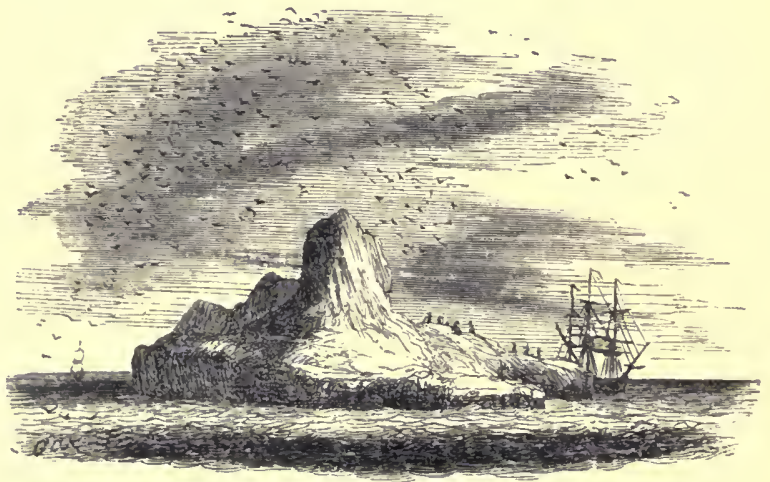

'The W:zard c f the Pacitic.' 


\section{$\mathrm{X}$. \\ THEORY AND PRACTICE.}

THE comparative failure of that portion of my first Turnip crop, which had drawn so heavily and so laboriously upon the meagre resources of the farmyard, produced a changed position of the game, which gave me some surprise. I found myself at length my own severest critic. Whether from the continuing force of that early prepossession in favour of the 'good old stuff', which had laid the bets-as heavily as the manure-upon that part of the field, or whether the fact of the mere germination of a turnip-seed where it had never shown its delicate cotyledon before, was triumph enough, it is hard to say; but somehow or other it was the fashion to semi-dignify with the title of a 'fair little crop' even those five acres which so wretchedly disappointed my own expectations. As for the crop where the guano 
was sown, it went off from the first sub silentio: it was stared at, and stared at still, as a sort of conjurer's trick which 'you couldn't do again.' Wise men shook their heads and held their tongues at it. Nobody would have been at all surprised if, on going to the field some fine morning, he had found it altogether vanished, like a faëry-gift, as quickly as it came : and as the roots swelled and swelled into confirmed substance and reality through September and October, the silence about it became perfectly portentous. Reluctantly the hoers confessed that they had not thinned it half enough; and indeed the loss, from that very common cause, was considerable. But where did the crop come from? how did it grow? by what means, short of the supernatural, could a mere powder, however highly scented, sown by the hand, produce this great fat thriving mass of roots and leaves? Surely it must at any rate be but a fraud upon the land after all; and the next crop would show the different results of real manure and a mere stimulant. This was the point to which OPINION at last settled down. ' We'll wait and see,' was the final determination expressed: and over many and many a farm in England and Scotland men did wait and did see. 
Of all the practical illustrations that ever appeared contemporaneously with the announcement of a great doctrine, the introduction and use of Guano during the lifetime of Liebig is one of the happiest and mosit remarkable. If some great physical event had testified to men's bodily senses the motion of the Earth round the Sun, and the steady centricity of that luminary, during the exact lifetime of Copernicus or Galileo; or if some conceivable reflection of the earth's surface in the deep azure of heaven, had exhibited to men's wondering eyes the outline of the great American continent looming along its obverse hemisphere, just as Columbus had departed in search of it,- they would not each have furnished a more triumphant vindication of the achievements of those master-minds, during their own existence, than that which the more fortunate Professor of Giessen has been destined to witness. No sooner had the persecuting infidelity of man (the same in every age) begun to crucify the great doctrine of THE NUTRITION of plants from the Atmosphere, than the use of Guano and of inorganic manures began to give it proof. 'Burn a plant, whether it be an Oak-tree or a stalk of Clover" (for so the assertion of the great Analyst may be briefly epitomised), ${ }^{6}$ and the trifling 
ash it leaves will show you all it ever got from the soil.' But the bulk, the weight, the great mass of its vegetable structure-where is that gone?

\section{' Into the Air :}

And what seemed corporeal hath melted Like breath into the wind!'

The weight, the bulk, the vegetable mass, of a crop, is simply, its Carbon. Combustion just undoes what GrowtH did: and nothing more. It recombines the Carbon of the plant with the Oxygen of the air, and their union is Carbonic-acid gas, the very substance which the leares of a plant feed upon in the air, where it is presented to them in its gaseous form, in which alone they can absorb it : they do absorb it; and in their clever little laboratory they pick out the carbon, and return the oxygen; just as our own lungs take up the oxygen and return the nitrogen. Multiply the two sides of an oak-leaf by the number of leaves on the tree, and you will be able to form some idea of the extent of surface, which the plant ammually presents to the atmosphere to carry on this work of absorption.

But the roots-what is their use then?

Examine them through a Microscope, and you will see that, as the Leaves are adapted to intercourse 
with AIR, so the Roots are adapted to WATER : not stagnant water: for the sponge rots which is always saturated, and their myriad fibres are each furnished at the end with a sponge capable of rapid expansion and contraction,- - suited therefore to a medium in which moisture should be ever on the move, downwards by gravitation, or upwards by capillary attraction. This is the true condition of the soil demanded of the mechanical department of husbandry. 'Pulverise your soil deeply,' said Jethro Tull, who thought that plants lived upon fine particles of mould: and he said rightly, but in so far as he said only half, and thought that was ALL, he thought wrongly.

But not more wrongly than every Farmer thinks who fancies that the bulk of his manure is its valuable part. He rather hugs his enemy in this, as he has done in other matters. The bulk and weight of Farm-yard manure is simply the carbon which it obtained last year from the Atmosphere; all of which must go through a long process of decay before it will have set free the Mineral and Ammoniacal parts, which together constitute, when dissolved by water, the suction-food of roots.

Liebig asserts, that if the roots are duly supplied 
with these mineral and ammoniacal substances, the rapid development of the leaves will soon obtain sufficient carbon from the air. The labours of the Dung-cart, as at present carried on, even in the most improved districts awkward and uneconomical, exhibit, under more backward management, a system of elaborate extravagance and loss, which the least chemical acquaintance with what we are about, would render utterly intolerable. By frequent turnings in the yard, and long exposure in the field, every opportunity for the escape of the Ammonia and every toil in the lifting, hauling, forking, and ploughing-in of the Carbon is lavishly expended. And all to little purpose. What portion the roots do take up has to be oxygenated in the leaf and decomposed again before plants will re-assimilate it: a subsidiary faculty which bountiful nature has given them, with different degrees of necessity for making use of it.

But in autumn and winter manuring it is otherwise. Decay is only slow combustion : and when you are burying great cart-loads of carbonaceous manure in the soil before winter, you are making a hotbed under ground, which will raise the temperature of the soil throughout the long reign of Jack Frost, and preserve many a tender seed that would 
otherwise perish : and herein lies the chief and wise application of all carbonaceous or bulky manure. Rightly, then, so far as their knowledge went, did our forefathers, who knew nothing of Turnip culture, plough-in their long manure before winter : a poor practice at best, we say, to put manure in immediate contact with a grain crop: but not more poor than to apply to a green spring-crop under the burning sun of June the treasures of the Farmyard whose spirit is exhaled before the body is buried, and whose body is not rotted time enough to afford its remnant of inorganic food to the crop it is applied to.

Who can wonder, then, that the 'artificials' should sometimes beat the long manure, for Spring application? And who can doubt that we wise moderns have left half our lesson unlearnt, in having changed the time of manuring without changing also the condition of the manure?

An experiment, whose object was to test the comparative merits of the Ancient and the Modern Fallow, seemed to some people almost unmeaning. The superiority of a green crop over no crop at all, providing that the land is dry enough in the winter for eating or carting it off when grown, was one of 
those public propositions that people had run away with in a hurry, and got their fingers burnt, and had to 'drop it' like a hot Potato, before they had had time to stop and look it in the face.

Fortunately I was a beginner in the full sense of the word. Fashionable opinion was no more a ' child of mine' than antiquated Prejudice. I had the same profound respect for each and both; that sort of profound respect which makes you take your hat off very low and keep a certain distance off. Not that I was in love with my own opinion, for I had none to be in love with. My agricultural intellect realized Locke's theory of the rasa tabula. Bare fallows had reached a respectable old age, if not a green one, in the world's history; I had no personal quarrel of my own against them; the half of the field set apart for the trial was hideously foul, and stiffer land than the part under turnips; manure was deficient, and spring-time busy : everything seemed to favour and suggest the comparison, so I made it. A dull, lumbering piece of work it is, too, to spend the 'long, long summer hours' in lazily turning the 'greate clottes,' as old Fitzherbert calls them, in that quaint passage where he cautions his brother farmers not to be in too great a hurry to brcak them: a piece of advice 
which every farmer has told, as a new discovery of his own touching bare fallows, from the time, three centuries ago, when Sir Anthony Fitzherbert wrote; and for three centuries before, perhaps.

But it is trying work, no doubt, to see the fields around you teeming with richest vegetation-nature all alive in every direction with the bursting wealth of present produce and maturity,-and to toil on nevertheless upon the bare and burning fallow, where the very dews of Heaven refuse their evening tear, and the morning ray darts wide in vain search after the liquid Brilliant that it finds on every grass-blade, every leaf, and every flower throughout the rest of Creation. One has heard of ' knocking a man into next week;' such a misfortune might chance to befal one inadrertently, and on suitable provocation: but to be ploughing next year for nine montlis of this one, and three of the last, to see everything around overtaking you as it were by a twelvemonth,-leaves growing more juicy and green, and crops getting richer and riper, and you and your fallow, like a sort of converse Oasis,-Desert amidst the Green,still dragging behind, 'feeding the air, promisecramm'd,' a heart-sick waiter upon the deferred hope of next year,-It is trying work, no doubt ! 
But Life is full of it: and especially of such as this. What is Education but a twenty-years' fallow, heart-wearying and self-denying of the pleasures that seem to bloom invitingly around us, luring the warm spirits and fresh feelings of youth, to the easy indulgence of more active enjoyment and contact with the world. What is manhood but a continued sphere of the same self-denial, another chapter in the biograplyy of Toil-for a future crop-amidst the wistful temptation of surrounding fruition. What is Life itself but a fallow-and bare enough to many a weary and assiduous toiler-a fallow for the future garnering of the joyful crop that was sown in tears.

And many such a truthful and intended analogy does the Farmer read, albcit no metaphysical scholar, in the Book of Nature's Symbols. They reach the eye of the mind through that of outward vision, without the need of types and words. ' It is not Speech nor Language, yet their voices are heard.' And shame upon the Parent, and the Land, that allows her sons to be banished, at the tender age of childhood, from the school of early instruction to the labours of the ficld, before the mind lias received that gentle care and training, which enlivens, explains, and even dignifies the lowest toil, if toil can 
ever be low, as only Ignorance imagines. The old Chronicler, amidst his own early blunders and extravagance, has yet had no occasion to correct the first impression with which he looked upon a child turned into a scarecrow for the new-sown field, a boy ' driving plough' the livelong day, and a man (A MIND!) threshing in a barn! without one hour for the instruction and development of that higher part which separates his mind from the instinct of the Brute, his body from Machinery!

Talk of ' Agricultural Improvements,- of the difficulty of getting the labourers to take to a new implement, or adopt an improved method! What enables you to see its advantage and adopt it? Your Mind. What cultivates your farm better than your neighbour's? Your Mind. If that alone be left uncultivated around you,-at every point, at every turn, in every field, in every furrow, in every hedge, in every ditch, in your House, in your Dairy, in your Stable, in your Barn, everywhere and at every time, by Day and Night, Winter, Spring, Summer, and Autumn-the neglect that has been allowed to sow itself, the moral weed-crop, will meet your eye to baffle and torment you with the feeling so truthfully expressed, when you say that you ' have not a single mind you can depend upon!' 
No wonder: you have never tried to make one.

Else, you would not have your Lime overslaked; as I had, during an unavoidable temporary absence while my twelve acres of bare fallow were in progress. Lime was all I meant to give them; except a thorough cultivation. Every ridge was levelled: not an elevation or a hollow remained: the subsoil that had been exposed through the winter was thoroughly intermixed: the plough and the subsoil-plough had equally done their work; and twelve quarters of lime to the acre was all I added, before the seed was sown.

My great object was to see the specific operation of lime upon a worn-out soil. If written words may be relied on, it is the most puzzling substance the farmer has to do with. The chemist tells us, and with truth, no doubt, that it has two distinct effects : one upon vegetable matter, which it helps to decompose; the other upon mineral matter, which it ' corrects.' Such is the word, and we must use it for want of a better. In the first operation it is virtually a ' manure,' because it turns into food for the crop organic matter which would else have remained inert: in the second it is an inorganic alterative, supplying calcareous matter, and forming 
a base for the free acids exposed in the freshly-moved subsoil.

I had taken some pains to ascertain the previous character of the field. Fifteen or sixteen bushels of wheat to the acre (undrained, in ridge and furrow) was the utmost crop the memory of man could furnish an account of.

The crop of wheat came up well, looked even and healthy, but not thick, throughout the succeeding summer, and ripened late. The produce, when threshed out, was six-and-thirty bushels, including rather more than half a bushel of 'Tail,' to the acre.

How completely the Lime had done its work, in both capacities, may be judged of from the fact that on a couple of acres which I retained expressly for the after experiment, and sowed with Beans and then with Oats, unmanured, the two succeeding years, the return exhibited an utter exhaustion of the productive powers of the soil, to an extent that I could hardly have believed, without experimental proof.

Though it cannot be desirable to see the practice of bare fallows extended; for it exists already upon many soils where it might be with every advantage 
substituted by green crops; it must yet be borne in mind that it is not in the mechanical structure alone that heavy soils differ from light soils; their chemical difference, which is quite as great, lies in that essential particular that the clay soil is naturally richer in the mineral constituents required by your crops. Potash, Soda, and Phosphorus, which you must supply to a light soil before you sow it, you have only to develope in a clay soil by deep and frequent stirring, and submitting it to the oxidation of the atmosphere. The green-crop, with its carbonobtaining leaves, will no doubt supply organic wealth to either; but inorganic food can come from the soil alone; and if the soil be able to supply it from its own resources, one-half the value of the green-crop, as a fertilizer, is renounced. Its remaining value, as a collector of organic matter from the atmosphere, is the point upon which the question will be poised, of its adoption on a soil which, after effectual drainage, sub-pulverization, and liming, still retains the character of a 'clay.' Even upon such land, (which is not so plentiful as some imagine,) experience has yet to prove how far, by deep ploughing and subsoiling immediately after harvest, and making the most of suitable weather between that 
time and the following summer, the useful Swede or Turnip may take its place in a six-course system, as profitably as in the four-course system upon lighter soils. The bare fallow is too ancient, too prospective, too laborious, and patient, not to have deep reason at the bottom of it. Chemistry has only explained the truth which Practice had established. The question may be, not whether the fallow shall be abandoned, but whether its objects can be achieved at a less sacrifice of Time.

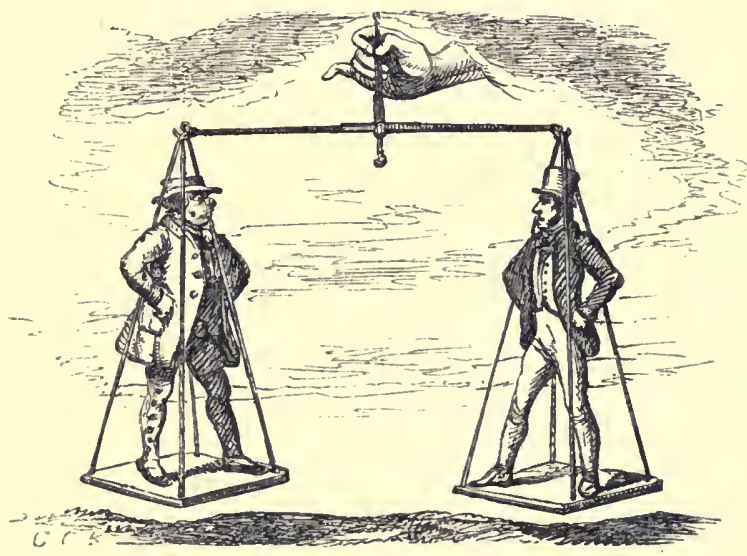

'I had the same profound respect for each and both.' 


\section{XI. \\ DISSOLVING VIEWS.}

Is the late busy days of Land-navigation, when a man could hardly travel twenty miles along the oldfashioned high road leading from anywhere to anywhere else, without rumbling under the skew arch, or half dislocating his mortal framework over the temporary bridge, of a 'Railway in progress,' as Mr. Bradshaw, with monthly mockery and pertinacity of promise, called it, most people had opportunities of noticing certain funnel-shaped pyramids of earth left standing in the 'cuttings,' which, if not exactly like their prototypes, -

'Flinging their shadows from on high, For time to count his ages by,'

yet answered very satisfactorily the more modern object of showing what deep wrinkles the face of mother earth may receive in short chronologies, and what geological liberties people take with her in her 
old age to what they used to do; inverting her established strata, shovelling Lias, Chalk, and Redsandstone over each other in most admired disorder, leaving only these frail memorials standing as if by way of a small sample of ' England before the Conquest' of spade and wheelbarrow.

When looking over the changed aspect of a twenty acre field, with its drained, deepened, levelled, manured, turnipped, barleyed soil, smoothly smiling under the sunshine in its first year's Clover, how often I have wished that some such relic of its original state could have survived, to present to the unimaginative eye that now sees it for the first time, the long story-

'Eheu! quantus equis, quantus erat viris Sudor!'- -

and furnish a reply of befitting smartness to the cold-blooded cruelty of look and phrase that extinguishes all your pride-full thoughts by some such damning praise as this:- 'Well! a very nicc field; a very beautiful field, indeed! very nice, but a-I don't see anything particular, not very particular, in it. I'm no farmer, you know ; you'll excuse me', \&c.

-'Excuse you! Why, what upon earth did you G 2 
come out to see?' I long to ask of each gaping sight-seeker, who seems to have expected a series of dissolving views, or some dioramic transparency exhibiting Drains running, Sub-soil crumbling, Ammonia fixing, Turnips growing, Sheep fattening, Wheat reaping, and all the phenomena that 'trammel up the consequence' of agricultural emprise, much after the fashion of the nursery tale that finds such rapid dénouement when ' the cat began to eat the mouse!'

Beautiful in every best sense of the word as an improved and well-cultivated farm may be, how bashfully does it reveal to any but the deserving eye, the eye that has rightfully and laboriously earned its perceptive power, the developed capability obtained by the soil from the judicious appliances of art. The Painter may draw a Landscape, the Florist may furnish a Hothouse, the Landscape-gardener may produce an 'effect' with compendious skill; but there are two things in nature bearing truthful analogy with each other, from the world of matter to that of mind, which defy the hand of imitation; both are comprehended by the one same word, cultivation. It carries no label, no title-page or illustration to the idle specu- 
lation of the eye : it is no talker ; you must give, it an understanding, but no tongue :' full as Nature is of ormament at every stage, she disdains to make an exhibition of her intrinsic progress at any. The railroad workman leaves a pyramid to mark the ancient outline of the surface; and it is wise in him, for he has a motive in the retrospective measurement. But with nature it is not so: ONWARD is the eternal word; and the memory how this meadow looked when it was that morass, or this fair field when it was that jungle of high hedges, stunted ash-trees, tangled bushes, with docks and thistles to correspond,-to say nothing of heaved-up ridges and crooked furrows,-all is past; and he who looks on it as it is, might as well ask leafy Summer to show him how Winter looks on the same spot, as expect the improved field to show him the history of its improvement. 'Oh! Sir, if' you had but seen this field as I remember it!' has been the half-mortified exclamation or remonstrance of many a worthy toiler upon earth's surface, whose handywork has left no landmarks except upon his own brow. ' If you had but seen it as it was ;'and there the interjectional sentence ends unfinished. Would it be far from the truth-a truth that will 
be one day better understood-to continue it thus:-

- You would give honour to the toiler and the toil that are employed in carrying out the bounteous designs of Providence for man, in subduing, fertilizing, and beautifying the spot of earth on which his lot is cast. You would ask why for thousands of years we have crowned the Warrior with Laurels, the Poet with Ivy, the Citizen with mural emblem, and the Husbandman with-nothing. You would ask why his achievements are without record and his name without honour; and his only reward that which is to be found in the words of the bitter satirist:- "Laudatu', et alget !"

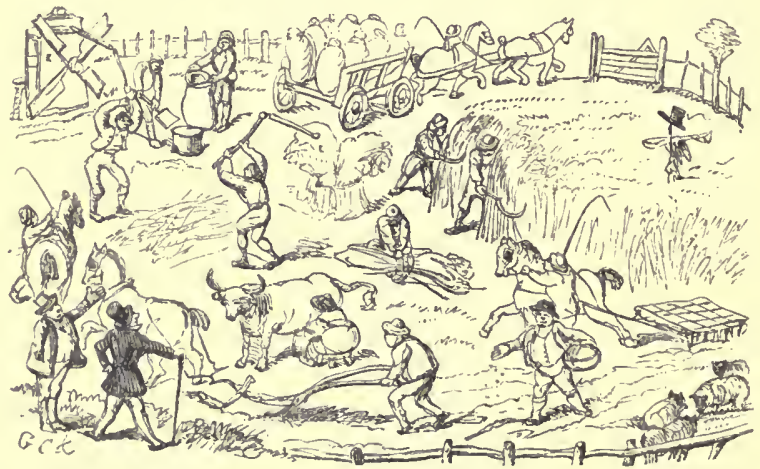

'Eheu! quantus equis, quantus erat virıs

sudor!' 


\section{XII.}

\section{A WORD AT PARTING.}

MURKy days of November, ye have come-and gone again,--over one at least who has found out and tasted of your Poetry : and in turning over the leaves of a crowded diary of years and days gone by, his hand can scarce touch without the gentle pressure of old fellowship the page after page that recounts the active business which lighted up even your dark atmosphere and drizzling skies; till the spent and scanty day again and again drove him, reluctant, to the ' bell, book, and candle,' from which the mind would wander back a-field, over every yard of nicely levelled drain ; and hear, in fancy, the drip drip drip going on through the silent night, while weary la bourers sleep, and Nature, the unwearied labourer, STILL WORKs, alone.

What a thought-to the mind that knows its history and value-ay! he may be bold enough to say who has known and felt it,-what a blessed 
thought is a well-drained Field! A portion, a small yet measurable portion of Nature's reality, brought by the hand of man from sterility to fruitfulness -from its first and incomplete existence to its intended and developed state. What a thought to cheer and lighten the dull November fog-that hundreds and thousands of acres in this moist England of ours, which once began their annual saturation with the Autumn rains, and lay in barren quagmire the livelong Winter through, unwakenable from the clammy trance of their yearly death even by the cheerful voice and breath of coming Spring,-are now gently transmitting through their porous texture, the healthful rain that feeds what it once poisoned; and that as every shower ceases, then comes a rich after-gift of atmospheric air following in a thousand sinuosities the threadlike channels down which the rain, like a pioneer, has found and led the way through the soil, to the very drain, three or four feet below the surface. What a thought is this, to those who know it, and have earned its pleasure!

Nature abhors a vacuum. True, most true, O philosophic chemist! Where the drop has once disappeared through the soil, it has dragged the air after it, and with the air, its burthen of medicament, 
food, and temperature, down to the once sluggish and unawakened subsoil that never felt its animating touch before.

' Oh! Sir! it's a fine thing, is this here draining,' said an old labourer, lifting up one heavy foot on the ledge of his spade, and composing himself with his elbow resting on the handle, to say a few words, before he put his jacket on and parted for the night. ' It's a fine thing is this here draining: what a crop o' Turnips 'll be here next Autumn, I'll be bound to say!'

Of all things I like to catch the toiler in lis spare but hearty moment of contemplation. The utterance of an abstract thought or reflection is never so precious as when it struggles from the lips of one whose frame is bent with the hard practicality of daily labour. I prize it beyond words.

'It is a glorious thing,' replied I; ' the more I see of its effects, the more I like it, and the more I wonder how the land was ever worked before without it.'

' Ah, well, Sir, 'twas a different sort of thing you see,-'twas like a different traade. Lor' blesh you, I remember the time when arter Wheat-sowing was done (and sometimes there was many fields so as it couldn't be got in at all, when it came a wet season), 
the farmer's work was over like, for the year. There was nothing to be done but sit at home and go to sleep, till the Frost came, and the dung-cart could be got a-field. It was bad work, Sir, for the labourer - bad work-when he was turned off for the winter, and had to look out for a bit o' hedging or ditching somewhere else, miles off perhaps, to get a bit o' bread by.'

' Well, we've changed that, however; I think I may truly say that every year, to me, Winter has been a busy time.'

' And it will be too! There'll never be standing still for winter work again on this here farm, as long as ever it lies out o' doors, let who will farm it! for all so many hedges are grubbed up. How the Swedes have growwd, to be sure, on that piece as we drained last year! I never saw Ship look better; and I remember when there wasn't a ship on the farm, or a Turnip on the ground to feed 'em with.'

' D'ye think that piece will stand the treading of the sheep?'

' Bear it! Lor' blesh you, it'll come up as mellow as a garden, I'll war'n' it, in the spring : it treads a little leathery in some places in the middle o' the lands, but that'll all come right after another crop : 
it don't all come at once arter draining; every year tells on it.'

'You think that really is the case?'

' Think! I knowows it, Sir. I likes it every year the better arter the draining: but I do think (no offence,) that you goes a little too dip with the tiles: it is no use going sa dip into the clay.'

'What, three feet! Why they laugh at me for draining so shallow! If you were to see what they say in those Papers I bring into the field sometimes in a morning, you wouldn't call this deep.'-

' Oh! never you listen to what them there paapers says : they knows nothing in the 'varsal world about it. They beent practical farmers as writes that stuff: none o' them as writes knows anything about farming.'

' D'ye think not? Well, but now suppose I were to write about the fields we have drained, and send it to some of those Editor men to print and put in the paper, wouldn't it do for somebody else to read: wouldn't it be as true after it was in print as it was before, when we were doing it?'

'Oh, that's a different thing, that is; 'cause of course they'd believe what you say

- Well, now-suppose I were to put it as a sort of history of this Farm, as it was, and as it is,-a sort 
of chronicle-call it the "Chronicle of a Clay Farm"-?"

' Oh, that's capital! Lord, how I should like to see it: that 'ould be summat like, that 'ould! none 0 ' them there long words about Chemists and Druggists and Doctors' stuff, as if farmers was a parcel o' hold women, like my poor old Missus —_- oh! thank you kindly Sir for what you sent her, it did her a sight o' good, she was able to eat her vittles better arterwards than she's done for many a day-'

' But you won't believe I can doctor the field and give that an appetite, eh Dobson?'

- Well, I don't know-I ben't no scollard, Sirone thing however, you've tapped the dropsy on it, for one thing, that's sartin!'

' And you'll believe the other when you've seen it. Well, good night, Dobson!'

And with a hearty ' good night' in return, trudges poor old Dobson home from his hard and wet day's work, with none the heavier heart or less elastic tread for a few cheery words to enliven the dull blank of the body's labour, and illuminate for a moment that hateful chasm that lies too broad and forbidding between employer and employed, in civilized England. 
When will this stain depart from our land? When will that moody silence and reserve that disconnects rank from rank, and class from class, and man from his brother man, cease to shut us up from each other's view, like sealed pacquets of humanity, destined and directed ' private and confidential ' each to its own special clique and circle, locking up the cheap yet gladdening benevolence of words from all 'below' it?

If man, vain aspiring man, did but truly measure the reactive influences for good, or ill, by which his own existence is surrounded; if he did but know the rich freight of happiness and of positive blessing to his poorer and humbler brethren, which he bears within him in the mere gift of language. If instead of reserving all his soft words for the rich, and the caressing of the tongue for those who least require or value it, he would stoop to remark its instant effect, and permanent influence for good, on those who seldomest receive it, how changed would be the working out of that strange problem of society which is ever leaving the largest numbers most uncared for, their power and influence only felt when it is dangerous!

Of all the sweeteners of human toil, of all the mo- 
tive powers that give alacrity to the hand or foot, readiness to the will, intelligence to mind and purpose, the quickest and the most enduring in result is the kind 'word spoken in season.' 'How good is it!' exclaims the Wisest of the sons of men. The most boorish obduracy melts at last under its repeated influence, though hard and rough at first as the unsmelted ore. Horse-power is convenient of appliance, Wind and Water power are cheap, the power of Steam is great, the sordid power of Money greater still; but of all the powers that be, to rid the tiny weed, or fell the stubborn oak, the greatest is that which can gear on mind to matter - the wORD and LOOK of KINDNESS.

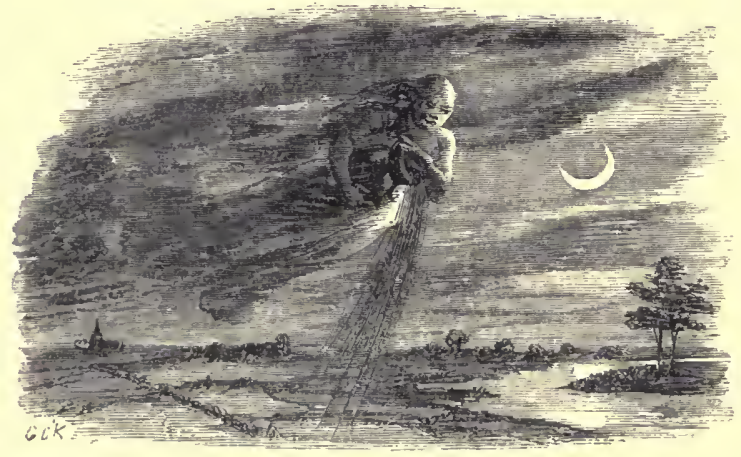

- On,"through the silent night,-

While weary labourers sleep,--still works, alone.' 
As event of almost national grief, which occurred at the noment when the Third Edition of this little work was preparing for the press, may be permitted to furnish a not unapt appendage to the words in the text, words which had met the eye, and received the earnest acquiescence, of the distinguished man and truly regarded friend who is the subject of the following notice:-

' Stafford, March 13.-Mr. Justice Talfourd presided in the Crown Court. He had reviewed the calendar, and was directing the attention of the Grand Jury to the number of serious offences it contained_-

'These crimes,' he remarked, 'come, I will not say exclusively, but in the great majority of cases, from those districts which are the richest in mineral treasures, where wages are high, and where no temptation of want can for a moment be set up as an excuse or palliation for them: on the contrary, I have observed, in the long experience I have had of the calendars of prisoners tried at these assizes, that in times of comparative privation crime diminishes; and that when wages are high, and are earned by a less degree of work, there is a strong temptation to spend them in vicious indulgenees, and that crime has increased almost in proportion to the state of prosperity by which the criminals have been surrounded.

'This consideration should awaken in all our minds, and 
especially the minds of gentlemen connected with those districts, to see in what direction to search for the remedy for so great an evil. It is untrue to say that the state of education in these districts is below the general arerage: then we must search among some other causes for the peculiar aspect of crime presented in these cases. I cannot help, myself, thinking it may be in no small degree attributable to that separation between class and class, which is the great curse of British Society, and for which we are all more or less, in our respective spheres, in some degree responsible, and which is more complete in these than in agricultural districts, where the resident gentry are enabled to shed around them the blessings resulting from the exercise of benevolence, and the influence and example of active kindness. I am afiaid we all of us keep too much aloof from those beneath us, and whom we thus encourage to look upon us with suspicion and dislilie. Even to our servants, we think, perhaps, we fulfil our duty, when we perform our contract with them, when we pay them their wages and treat them with the civility consistent with our habits and feelings, - - when we curb our temper, and use no violent expressions towards them. But how painful is the thought that there are men and women growing up around us, ministering to our comforts and necessities continual inmates of our dwellings, with whose affections and nature we are as much unacquainted as if they were the inhabitants of some other sphere! This feeling, 
arising from that kind of reserve peculiar to the English character, does, I think, greatly tend to prevent that mingling of class with class, that reciprocation of kind words and gentle affections, gracious admonitions and kind inquiries, which, of ten more than any book education, tend to the culture of the affections of the heart, the refinement and elevation of the character of those to whom they are addressed. And if I were to be asked what is the great want of English society-to mingle class with class-I would say, in one word, the want is the want of Sympathy. . . . . While uttering these noble sentiments his head fell on one side.

'The latest breath of one whose whole life was kindness, * was thus spent in a solemn enforcement of the duty of kindness to others. He was urging upon his countrymen, on behalf of the fallen and falling, the need in which we all stand of " a reciprocation of kind words and gentle affections," when his voice was hushed for ever.

'Noble indeed would such a doctrine have been, and most fit to be delivered, if it had been no more than it was meant to be, a voice of mercy from the judgment-seat : a voice of justice perhaps more true than speaks in many a judicial sentence. He was discharging his official duty, but he was urging not less the lesson of his own generous life, when he attributed the fre-

* Examiner, March 18, 1854. 
quency of crimes to the denial of that best education which is given by the sympathy that should exist between high and low, by the active kindnesses and the gracious admonitions that ought to bind us more nearly to classes from which English habits of reserve keep us now too proudly aloof. He was speaking that which he knew, and his breath, after the grave utterance of that warning, could not expire in a strain more sweetly,accordant with the whole life's music that had gone before.

'That such should be the end was the Will of God; and never did robed and ermined judge, dying thus in open court in fulfilment of his duty, meet a death so like that of a hero. With Talfourd's name the memory of that last hour will never cease to live. It will remain on earth and be a fruitful source of Good: and there is a pause in sorrow when we think that it will be remembered too in Heaven.'

[ENd of THE FIRst SERIES.] 


\section{[SECOND SERIES.]}

\section{XIII. \\ 'FARM TO LET.'}

THE town of Bogmoor is not famous in History: nor indeed geographically. It may not perhaps have challenged a very responsible amount of public notice hitherto, either for its own merits in general, or for that reflected virtue in particular, which has cast a queer distinction upon Marlborough, Wellington, and a few other ' small towns with great names' that might be mentioned; and that sometimes are mentioned, with a yawn of careless wonder, why 'Duke of Blenheim' and 'Duke of Waterloo' wouldn't have done as well,--perhaps better, than tying on the name of an obscure town to the laurels of the hero, like a penny ribbon on a prize Longhorn.

But however, that is not the present subject,- 
indeed as far from it as possible,-for the real point was to show that whatever the world at large might say or think, or not say or think at all, about Bogmoor, it had a comfortable kind of self-opinion of its own that amply outbalanced all public indifference. Indeed the place was utterly chloroformed against any such sensibilities, and was quite of the 'opposite way' of thinking; reminding one of those people often met with, who for some cabinet reason that never can be got at, seem to view every object in life through that lens by which the dilated eye of the drunkard is said to make everything he meets look small. As you walked or rode up its one long flat dull straggling street, it was strange to remark the contrast between the street itself and the faces that met you in it. How upon earth so much self-satisfaction had ever been got together in so unsatisfactory a spot, was the indefinite wonder that was stirred afresh in the mind by every object that met one's eye. The very curs popping extemporaneously out of wet narrow alleys, imaged, while partaking of, the character of the place, cocking up head and tail as you passed, and exerting both together in one short 'Who are you?' bark of indescribable impudence. 
Whether in aggravation, or explanation, of the whole scene one can hardly undertake to say,-but there was one large bow-window visible a long way up the street and down the street-and indeed up and down another street too, (the only attempt at a cross street there was,) for it was a corner window, commanding therefore at a glance all the news of the town.

Ay! and a deal more too! Its wide look-out was, like the little dogs just observed upon, symbolic as well as actual. It was the News-room, Readingroom, Petty-Sessions-room, Literary-and-Scientificroom, Farmers'-Club-room, and a great many other' rooms besides, that there is not time to tell. Enough to say that the smallest pin ever manufactured could hardly have alighted point downwards on the floor of that room-metaphorically to speak-but everybody heard it ten miles round, and could tell you the shape size colour and manufacturer's name within the twenty-four hours: and that was short time in those days.

I shall not describe that room or its bow-window any further. I conceive that the heaps of newspapers, with the noses and spectacles poring over them, and the polished mahogany tables, to sit and 
read them at in the windows, so as to command the news inside and outside, are sufficiently visible to all average minds'-eyes without more specification.

Now it happened that at the top of a column in the advertisement-page of the 'Wetland Mercury,' which was lying fresh and damp from the press, and casting a hazy pattern of itself upon the polish of one of those same mahoganies, there appeared one Saturday morning in the autumn of the year Eighteen-hundred-and-thirty something, a short dab of an advertisement in the following spasmodic phraseology :-

' Wethandshire.-Farm to let; on Lease. 250 acres. One third Meadow and Pasture. Has been drained and otherwise improved in the hands of the proprietor. Capital required, 10l. to the acre. Application, to Messrs. Penn and Debbitt, Bogmoor, Wetlandshire.'

'I say, Mr. Bowles, have you seen this Farm that's advertised here?'

-said a gentleman sitting in the window, to another gentleman, in deep perusal at the fireplace, of which he had taken sole seisin, holding it by the hobs with his feet. 
'Yes:-No: What is it:' said the voice from the fireplace, uninquiringly, and smothered in a ' leading article.'

' Why here's a Farm of two hundred and fifty acres to let ' drained and otherwise improved by the proprietor.' I wonder whose it is: that's just the sort of farm young What's-'is-name was wantingthat 'ou'd just suit him, wouldn't it?'

'Well, what is his name', returned the other voice, uninquiringly again, and never looking up.

' Why young-oh! what is his name-I shall forget my own soon'-(a grunt from the fireplace) ‘-young Leejohn, you know him. You don't mean to say you don't know him?'

' I didn't say I didn't,' answered Mr. Bowles with provoking gravity of iteration, bent upon giving the smallest modicum of intellect to anything else till he had finished his ' leader:' which having just accomplished he starts up, lets go the hobs, and parting his coat-tails, turns round, and again takes possession of the fire; indescribably; and waking up to the subject, asks,

'But how can he take it: you said 10l. to the acre didn't you? He hasn't the money. ('Legion' indeed!) 
" 'ord blesh ye!"

Added to a toss up of the chin out of the cravat, to give emphasis to the middle word, this invocation conveyed all the answer that was heard, to the difficulty started by Mr. Bowles. What the exact meaning was that lay wrapped up in the blessingwhether it was peremptorily favourable to young Leejohn's pecuniosity, or conclusive of some indifference attaching in toto to the inquiry, has remained dark to the present day. The subject fell, strangled by some larger topic of news-room discussion : and the Chronicle is without a scholiast.

Two or three days after the appearance of this epigrammatic announcement in the 'Mercury,' a thick and weighty-looking pacquet, directed in what may for contradistinction's sake, be called ' Squaretext,' might be seen lying upon the margin of a breakfast table on which lay also an admired disorder of newspapers, books, farm accounts, and coffee-cups. The room itself in which the table stood is just worth a moment's notice before anyone comes in. Small, oak-panelled, and too square for good proportion, it was crammed, in every corner and upon every table, with miscel- 
laneous piles of articles which seemed to have grown together by degrees in spite of original incongruity, and become reconciled at last, after the manner of other foes, by lying under the same dust. 'Indoor' and 'out-o'-door' seemed to contend for the mastery all over the room: if you looked into the corners you might have fancied yourself in a garden tool-house, if you looked on the mantelpiece you thought of a chemist's shop: four dried lumps of soil, as hard as stones, lay at one end of it on separate pieces of ex-white paper, and through their coating of dust feebly indicated the three primary colours, blue red and yellow, with a sort of grey for the fourth. Over several tiers of newspapers between the windows, at the further end of the room lay at full length two ' new and improved' Drainage-levels,_out of Spirit though,-_for each was carefully tied up with a direction card to the maker: ' rejected addresses' evidently. Odd combinations, unmeaning and half meaning, disported themselves over the confusion of the little den : the end of a large pruning-knife peered out between the sheets of a new half-cut volume marked 'Dendrology,'suggesting something about Theory and Prac- 
tice, and clearly exhibiting, by the jagged leaves, the moral as well as physical truth that sharp knives are bad paper-cutters. An old quarto volume of Raleigh's History of the World, in black letter, lay open on a little table near the fireplace, with a bundle of Cigars and some papers of Potato-seed on one page;- -and a small sharp Axe on the other. A whetstone lay near, and a drop of blood, along the edge, had left mark of some awkwardness or haste, and had smeared the page below with an ugly red line just under the word Gratiture. Except a tolerably well filled book-case too much stuffed with stitched Reports and periodicals, there was nothing else noticeable in the general medley, excepting an ingenious atrocity in the shape of an easy chair, with a traversing desk and a shaded reading lamp screwed into one of the arms. A wood fire had burnt out in the hearth, leaving the ends of the brands reclined despondingly against the fire-dogs, - old-fashioned biped articles, which reared each a neck and head of silver, by way of focal ornament and finish, and which people who came on business always fixed their eyes upon, and at some convenient pause registered their approval of, in a tone that took credit for originality of taste. 
The windows looked eastward, and the sun was shining in; the weighty-looking pacquet had not been long on the table before the door opened, and a shooting-jacket, waistcoat, and trowsers, all of the same pattern, entered the room : a cup of coffee was hastily poured out, and the seal of the pacquet broken. A quantity of letters fell out; one of which ran as follows:-

' Dear Sir,-We enclose to you applications for Farm, marked 1 to 14, of which be pleased to return those you wish answered. Six parties called yesterday, wishing to inspect personally and have refusal of same. We will forward you further particulars to-morrow.

' We are, Sir, yours very truly,

'Penn and Debittт.'

' Marked one to fourteen-plus six,' muttered the owner of the shooting-jacket, slowly putting down the letter amongst the other's, seating himself in the arm-chair and swallowing the lion's half of the first cup of coffee. 'Two days' notice-' no! not so much ; not two'-and twenty applications.-Hmm!' 
Having delivered himself of this reflection with that deliberate and abstracted utterance betokening more thought than syllables, he gradually fell into a posture-the head upon the hand and the elbow on the chair-arm - which indicates that state of mindderiving its name from the cloven-footed race who patiently swallow things twice over, dining at one hour and chewing at another,-yclept Ruminating.

' And so, my poor old Farm, I must now bid you farewell. I who have taken your part through good and ill report,- -know the course of every drain and could find blindfold every weeping outflow that has wrought so fair a change in your once untoward look, and ill name: earth's tears of penitence and Promise! I who have taught you by anxious toil through many a long dull day that serene and smiling look you wear this lovely morning, which even in your plain face betokens something good at heart. Well! may he who wins deserve,-as many a sad heart has said, after all its watchful care, in cases not altogether dissimilar.-Now let us see something of the suitors !'

This last remark seemed to have reference to the heap of letters ' marked 1 to 14 ,' but before the 
action could be suited to the word, it was arrested by something which aforetime has, in fact and fiction, arrested a good many words and actions, - a gentle KNOCK at the door.

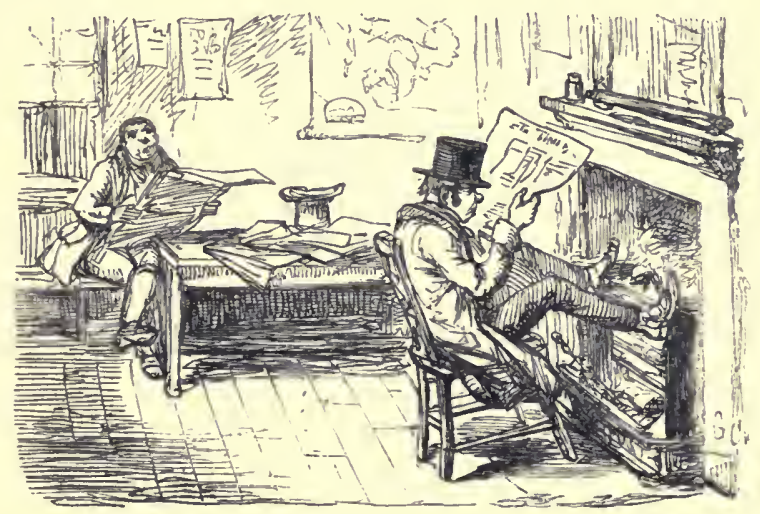

'I say, Mr. Bowles, have you seen this farm that's advertised here ?' 


\section{XIV.}

\section{AN 'APPLICATION.'}

If there is one class of mind in the world with a native antipathy to improvement, there is another and much more really mischievous, that seems ever destined to caricature it. As every animal, however noxious and seemingly useless, has its appointed prey, so do the natural enemies of all scientific advancement in their own art, trade, or calling, whatever that may be, find a never-failing source of triumph and enjoyment in cracking the bones of blundering Enthusiasts who dog the path of progressing Truth, like distorting shadows, throwing her calm clear profile against each passing object, in every variety of burlesqued and ridiculous outline. It has puzzled philosophers of limited patience and observation, to reflect upon this fact: forgetting, or never having noticed, the "gentle-handed tolerance which marks the parent-discipline of Nature, over her inter-squabbling and mutually-intolerant chil- 
dren, they wonder she interferes so seldom, and with such mild half-measures, to rescue her beleaguered sons if not from the foes in front, at least from the fools behind who go bleating about, exaggerating every fact, like street-newsmongers; dressed in the livery of science, like a monkey in regimentals, and understanding and appreciating the language they talk at second-hand, as much as the organ-grinder does the opera-tune his winch works threadbare.

A good solid inpenetrable advocate of oldfashioned ignorance, falling foul of one of these light gentry, snaps him up at a mouthful; and no harm done neither: but the mischief lies in the corollary-'So much for your Science !'

Agriculture has had enough of this, and something to spare. Counterfeits of every sort and shape have crowded at the heels of every improvement, every invention, every good suggestion, every new manure; till Art and Science are well-nigh ashamed of the sound of their own names, and are fain to wear smock-frocks for incognito. The plague that has reached its height in the present decade, was beginning its infective process in the last, of our nineteenth century. It knocked that gentle knock 
at the door that ended a late chapter of our chronicle; and it was ushered in (as what plague is not?) in the most pleasing and attractive form imaginable.

A very young and fresh-looking little personage, very smartly dressed, having sat himself down, and got pretty well at ease in the course of a preliminary announcement that he had ridden over thus early in consequence of a visit to Messrs. Penn and Debbitt on the previous day; without giving much occasion of reply, proceeded to deliver himself of a little harangue of which the world at large having already been delayed the benefit, some ten or fifteen years, must now content itself with an abstract.

It appeared-from this discourse-that Agriculture was a most interessting hart-but quite in its linfancy-quite entirely so. The farmers were a very hignorant class, and knew nothing whatever about it-nothing what-hever. The land did not produce enough by arf-not a quarter what it hought to deu. Summer fallering was a shocking waste of time and expense: a pair of 'orses were enough to plough the stiffest land-to any depth. Farm-yard dung was good for nothing. Gro-anner was the thing; and the four-course system, which no 
landlord ought to allow 'is tenants to adopt any hother. Six feet deep and forty yards wide was decidedly the proper depth and distance for drains, and if the clay was well stamped down upon the tile this would drain the wettest land hamply and effectchally. But no hagriculturist could be expected to lay out his capital in these improvements without a Lease-nineteen years at least, as they ave in Scotland. With a demand of which-after many other useful hints about Game, \&c., the lecturer concluded his remarks; offering to exemplify them in his own little person upon this identical ' Clay Farm.'

The stupid old Chronicler meanwhile-(the wearer of the shooting-jacket before-mentioned) during this eloquent outpouring, seemed somehow to have got into the clouds. During the first half of it, he had never taken eyes or ears off the speaker; when at length he did, it was only to put his hand and handkerchief over the former, so that they were quite buried; though once or twice a keen observer, not himself oratorically engaged, might have just perceived a very slight spasm or convulsion of the figure, and a sudden redness of the temples over the edge of the kerchief; but the momentary cough, or 
sneeze, or whatever it was that ailed or choked him, passed away; - and when the address was over that had been charming so long and wisely, he looked slowly up, like a person whose thoughts had been wandering far away, and must be recalled, like a lot of stray heifers, before he could put the question-

'Have you farmed largely, Mr. ___ ?'

'No, Sir; not exactly-at least-not myself yet; but I've seen a deal of hagriculture; that is, I've been over some of the most celebrated agricultural establishments, that of $\mathrm{Mr}$. Speedwell in Netherlandshire-the Rev. Mr. Forcechalk's Farm on the Highdowns : I've been over Lord Burytile's Drainage-works in North Dampshire, with his Lordship's steward; and I am familiar with $\mathrm{Mr}$. I'Scuffler's great concern in Inthemess-shire, N.B.-I know Mr. M'Scuffler very well. By the way, I presume, Sir, you allow a tenant to take hout?'

'I beg your pardon?'-

' You would allow me, I say, to take out-a-I'm not much of a sportsman myself, but if a friend should come_-

'A certificate-oh! I understand:- You've 
seen the Scotch farming then? did you study long with Mr. M'Scuffler?'

'Oh! no: it wasn't to study: I often go and stay with him: ah! that is farming! He asn't an acre of grassland: not a bit except the grassplot before his door, and he says he shouldn't keep that except to wipe his shoes on.'

'Ah! well: we are rather proud of our dairy pastures, though, here. Are you married, Mr.——? Excuse my-'

' Not yet Sir; I'm going to be Sir! It's on that account I mean to take a farm. I've a thousand pounds of my own; and She-that is-her aunt, who died lately, left her a thousand pounds; rather more I believe-so we shall have plenty to begin upon. Mr. M'Scuffler has promised to send me a Scotch plough and four capital orses,-Clevelands - such steppers! you'd be astonished to see the rate they go over the ground.'

"Are her family connected with-with "Agriculture,"-is her father a-'

'A Farmer? oh dear, no! He was a commercial gent: but he is dead: she was living with her aunt till lately.'

A few moments' pause ensued: the free youthful 
expression of self-confidence on the face of the speaker contrasting curiously with the somewhat puzzled and painful thoughtfulness expressed by the other party to this brisk dialogue. This expression however suddenly changed, and getting up and going to the book-case, he pulled out-as if in reference to the discussion just pending - a thick quarto volume; and having blown a little cloud of dust from it into the fire-place, and rapping it together once or twice, apparently to complete the purgation, he walked up and quietly laid it down open before his visitor.

- Would you oblige me by reading me a page of this ?'

The other stared-' Read this! Why, gracious me, Sir; I can't! Why, it's Greek or Latin or somethin'!'

'Three lines will do.'

' I can't Sir, really ! I couldn't read a word of it if you'd give me the world !'

' One single line.'

'I can't indeed! I never learnt a word o' this stuff.'

'An agricultural author too! His name is Theophrastus. It's all about Wheat, Beans- 
Egyptian beans - the same you buy at Mark-lane kiln-dried, and all sorts of other plants and vegetables. Surely you can read it?'

'Not if all I have in the world depended on it? I never learnt the alphabet!'

Thank you, my young friend-that's an honest answer. Now observe: you are going to pledge "all you have in the world," and all that Somebody else has too-that you can farm; and you've never learnt the alphabet! The task you see before you in that book, and think so difficult, is but the acquirement of a few years; the other is the labour-of a life-of many lives-and not learnt yet. I'm not joking, believe me. I speak seriously; I've burnt daylight and candlelight-a fair share, over both. Why do you think - why does everybody thinkthat he can farm without having learnt how! that agriculture (if you like that word best) is an exception to every other human labour or pursuit, a contradiction to all Natural Law, and will bring a livelihood without study, cost, or apprenticeship: that to be able to gabble over the pet jargon about the ' hignorance' of our forefathers-'

The old Chronicler was warming up-and beginning to lurch about in his chair like a grain-laden 
Dutchman warping out of harbour;-but a look of something in the other's face just happened to catch his eye-a look that somehow can break downand go right through a barred and bolted door better than artillery and powder-bags-a look that trips up anger and throws it flat on its face-that melts arguments into a jelly-a sort of look between simplicity and penitence-a slight quiver about the mouth as of a child convicted in a first fault-

The steam was turned off in an instant-the safety-valve opened of its own accord: that precious valve that the Great Architect has placed in the inner heart of man, no matter how many rough coats are wrapped over it-

'Come, come! We'll make a bargain after all. An early visit deserves to do business. You're still young-very young. Take a word of advice from an old head. Go to your friend $\mathrm{Mr}$. M'Scuffler -ask him to take you for two or three years:-it's soon gone. Work away for dear life at his farm, and make him tell you all he knows. Fancy that it is your money instead of his that buys every ton of manure he spends. Put off your wedding a little bit: She'll be constant if you are: and come to me three years hence; I was as young as you once; and 
when you're as old as I am you won't repent my advice. I'll look out something by that time that will suit you better than this.'

There was a shaking of hands. A promise on both sides: The door closed: and the momentary flush of warmth fell away from a pair of old cheeks, like a red oak-leaf from the bare bough of November, as the letters 'marked 1 to 14 ' were slowly taken up one by one, and glanced at with the leaden eye of habitude.

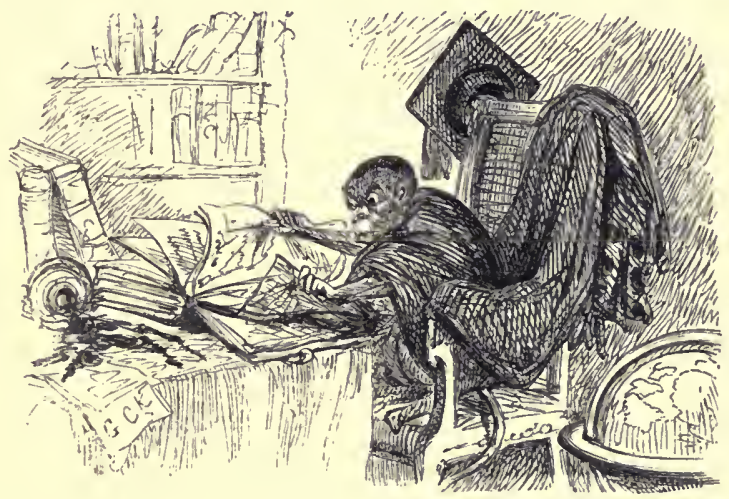

-"but the mischief lies in the corollary-" so much for your Science.' ' 


\section{$\mathrm{XV}$.}

\section{'LANDLORD AND TENANT.'}

To people of that happily constituted mind in which the hope and faith in the moral progress of our race, and the sanguine watching of its slow-creeping evidences, furnish a continual, albeit a slender banquet, -whose patient and far-reaching charity may be truly said to 'feed upon air, promise-crammed;' it must furnish an occasional, and not infrequent pang almost of despondency to witness how slightly, how remotely the best remarks of the best philosophers, the most practical advice of the most practical moralists, does actually reach, touch, affect, enter into, or flavour the reciprocal thoughts and actions of men in the working-day routine of ' business' life. Business is the word, business is the excuse, business is the conventional and accepted basis for a code of human action, as unlike and opposed to what is declared, and believed, to be conducive to true happiness in every other department of life, as Monday's 
conversation is sometimes at variance with the feelings and resolutions experienced at the close of Sunday's sermon.

It is as long ago as the days of Charles II. that in one of these same 'Sunday sermons' a remark was made which has not only travelled down safely to our own time, but enjoyed the more remarkable truth-stamp of instant activity in its own, in being carried away by two listeners, who the following day met each other half-way to shake hands, and settle by a little mutual concession some matter' that had long kept them wide apart. The remark was that ' Selfishnesse seeking but its own sunshine is blynded, lookynge on the light; but wisdome, like a true archer, turneth his back to the sunne, and letting the light fall upon the object, taketh the steadier and surer aym: and thus should he who seeketh his long happiness consider well the posture of his neighbour, and placing himself therein, look back as it were upon his own; and most surely, after due habit (for the tryal is at first of difficult empryse), he shall find the whole matter between them such as one may presently know wherein the due correction lyeth.'

To those complicate relations of life in which there is at once antagonism of interest yet mutuality of 
object; to that relation (for present instance) implied by the words 'Landlord and Tenant,' how close, how admirably apposite seems the quaint rule laid down by the good old churchman! 'Place yourself in your neighbour's position,' he seems to say) though indeed his language needs no paraphrase), ' and look back upon yourself from that point: the thing is difficult, and there is little danger of your getting too perfect in the art of looking on your interest with your neighbour's eyes. Let the Antagonism between you be for the time imaginary, the Mutuality real. So will you see your own best interest and happiness in truer light and leisure, by taking your neighbour's judgment, even for his own ends, into council with your own.'

The too frequent practice is to do the exact reverse: to realize the antagonism, and make the mutuality a fiction and a humbug. What the effect is -first upon the soil, secondly upon the labourer, and thirdly on the public wealth, wherever this mistaken system has been long in operation, let him say who has seen a country, a district, or even a single acre which has been the arena of pure unmitigated selfishness, on the part of its Owners and Occupiers, and all who come between the two. The signs are not 
easily mistakable;-beggared labourers, beggared parish funds, and beggared public finances can be recognised afar. They reach every sense: the eye can see it, the ear can hear it, the nose can smell it, the hands can handle it. In time the perception reaches the inner senses: and the mind begins to understand that this corruption is the work of mistaken selfishness. The social laws of Nature press gently and agreeably around a man, till he offends them by long neglect, and the selfish notion that they can be starved and stinted, harmlessly. Then they come in force: and evince their presence and reality by pain, instead of pleasure. Then the great problems of society begin to work themselves out under high pressure.

In the early stages of the world they are simple enough. When every man tilled his own field, the duties of Landlord and Tenant needed small definition. But advancement complicates relations: presently the time comes when you begin to see one man cultivating the soil of another: and that not only without wages, but paying the owner for leave and license! Mouths have increased upon the land; but the land measures the same. Acres don't grow. New inclosure eases the pressure for awhile; and 
like the rising water-mark of a flood, the ploughline steals up the mountain-side-higher-and higher yet,-it grates upon the bare rock-and stops. But what has happened meanwhile in the rich valley? Industry, skill, perseverance, prudence, self-denial, far-sightedness,-all, some, or one of these qualities have made individuals-or their lucky heirs-owners of more than they can cultivate themselves. The last bit of moor or mountainside was the measure of the extreme point at which cultivation would pay; that bit, langing between earth and heaven, in more than one sense, was the balancing-point, the test of cultivability. It just pays for tillage; and nothing more. A man perchance may ask your leave to dig or plough it: but for that leave he offers you no return-no Reddendumin modern English, no RENT.

Here then is the origin of that curious thing whose definition has sorely puzzled the Political Economists. And well may it have puzzled: for it is the basis of one of the most complicate and pcculiar relations that has come to exist between man and man. Mutuality of object, antagonism of interest, upon the same ground, raise a demand upon each of the parties for one of the most difficult 
things that human nature can be asked for-modified self-interest. It is easy to say that Land may be let like a House, or a Wharf. So it may. But with the mere lease ends all the similitude; except such as lies between dead stone walls shaped and laid together by human hands, and the living teeming earth whose fertile bosom is impregnate with the perpetual action of a life-producing agency. We talk of the 'constituents of the soil,' and something we may know of them: but who can unravel the wondrous tale of their intercourse and inter-action, or bind them captive to the dry covenants of a motive-chilling lease? So may a leaf or a flower be 'manufactured,' or an animal 'carved' in wood or stone: but they are deficient in that one element which was said to have reached its acme from human art when the Watch was heard ticking in the pocket of the dead soldier.

In a word, brick-and-mortar walls, lath-and-plaster partitions, oak floors, and marble chimney-pieces, are dead things, the fitting subjects of a dead contract; but there is a still life, a rebounding vitality for good or ill in the Soil,-the glorious handywork of a higher manufacture-that will hardly brook the dull sloth of sleeping partnership. 
Not organised itself, it is yet the active Source of Organism. Its gifts come to man duty-laden. To take the one without the other is, in the long run, impossible. And curiously enough, the Earth is herself the first witness of a breach of the duties she devolves on and between those who cultivate, or inherit her gifts, as she was of the earliest wrong committed between man and his brother man. She speaks, with most miraculous organ; and tells you the character of the cultivator, or the proprietor, or both, as plainly as your eyes may choose to read it.

Take a walk through an Allotment ground. 'To an expert eye, does not each little oblong plot of land, with its varied produce, care, culture, and condition, tell its separate tale, as if the soil were the destined mirror of the hand and mind of man? Does it need the voice or finger of the showman to point out the characteristics of the several occupants? Here there is industry, there idleness: here again is hard labour, without skill or knowledge; there you have experimental attempts, despising established practice overmuch, and ending in failure: here again is toil over-tasked and struggling against want of means-the spade without the 
dung-fork-a hard and pitiless struggle; there plenty of manure-heaps, but wastefully and unevenly applied: here again is loss of time upon too close a minuteness and pettiness of culture, there too large and daring a system, which risks the whole space upon a single crop. Every variety and subvariety of character is self-drawn and pictured on the soil, a photographic portrait of the cultivator. And so it is upon that great Allotment-field-could one but as easily look over it-the farms spread, border-to-border, over the various geological systems of England, Scotland, and Ireland.

To this same wide Field, with its many modes of tillage, its various kinds of produce, and equally varied character both of occupation and of ownership, insensibly flew the thoughts of the puzzled reader of a certain budget of fourteen letters, and of another about the same in dimension, which the following post brought from the punctual Messrs. Penn and Debbitt.

Reflection might well be allowed to be more longwinded, and Imagination itself to be more fanciful than usual even with the Chronicler, when-arrived at the end of the last of these missives and the 
questions they contained, as varied as the Postmarks they bore,- -he threw his eyes up at a many-coloured Geological Map of the United Kingdom, hanging close beside him, and pictured to himself the possibility, and the value, of just such a Map, with its strong colours under-shaded by the 'Agricultural customs' that further sub-divide its geological outlines. The curiously contrasted interrogatories supplied by the letters he had waded through-for questions are mostly fertile in self-disclosurewould almost have furnished rudely the outlines of such a Map. Perhaps, thought he, before the century is out, the dream of 1835 may become an useful reality.

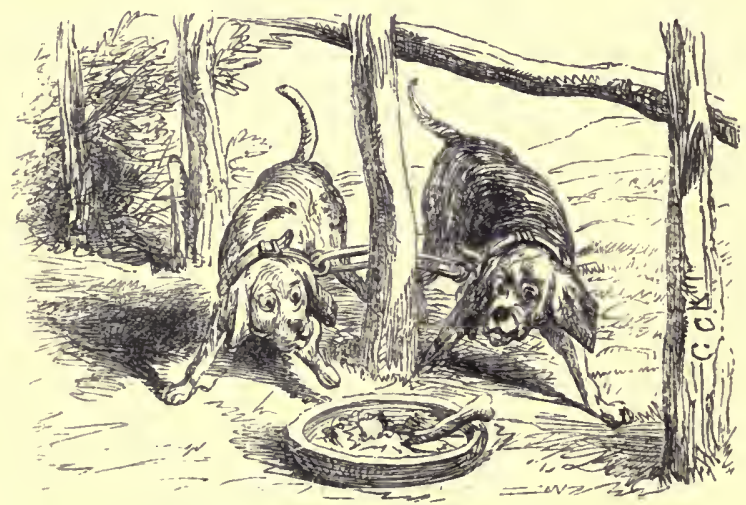

-'In which there is Antagonusm of interest yet Mutuality of object.'- 


\section{XVI.}

\section{LOW PRICES AND LONG FACES.}

DAYS-weeks-months-how you drift away! bearing the present time with all its clamorous and busy sounds of life, into that long wake that stretches far-farther than the eye can reachbehind us! How you float past-boiling and tumultuous at first, as just escaped from the din and turmoil that marks the everlasting conflict of our onward course-then gently and deceitfully subsiding off with only a rising ripple here and there, that beckons to the eye and tells of something that will be remembered-some duty unperformed - -some happiness perceived too late ; - then, at last, sinking away into the smooth surface that stretches far behind in undistinguishable outline, blending near things and remote into one great PAST, and leaving us to wonder at the intensities of fear and hope, of vanity and usefulness, of evil and of good, 
with which each moment as it passed seemed pregnant !

How wise we are, as we look back! How clearsightedly we discover each blunder, and its cause; how surely we believe that here at least and there at least-forgive us this once, O Common Sense and Judgment!-we will promise never to be such fools again!

Did ever man build a house-or farm a farm-or even drain a marshy meadow-and not feel some touch of this provoking after-wisdom that comes too late, telling of material and money wasted-plans insufficiently considered, too hastily accreditedtiles mislaid, too shallow or too deep, or in the wrong direction? In the matter of brick-and-mortar such aftersight is grown a proverb; and is it otherwise in land? Let him who has never felt it, cast the first stone: he has known little of Life's learning who has never repeated to himself how true it is that Experience is never given, but always bought; and at the top price of the market?

But there is this consoling difference between Bricks and Tiles,-that is to say, between Building and Farming: that whereas in the former case you always find your cost in having done too much, pro- 
ceeded on too large a scale-in the latter case you mostly find, such at least was my discovery-that your unprofitable expense is for ever peeping out in the niggling nature of your plans-field by field, hedge by hedge, drain by drain, a tank here, a cowhouse there-you have waddled through your Farm, denying your better instincts, resisting the true economy which would have prompted a complete and comprehensive plan that looks the whole matter in the face at once: as though a man should build a mansion room by room, and paint and furnish and roof them in, one by one, solemnly counting the cost all the way, and shutting his eyes to the conviction that the next room-and the next story, must come at last, -and that one roof, one plan, one outlay, the cheapest because the most compendious, might have covered all, and saved the worry and mortification of jobs undone, arrangements altered and blunders deplored.

Architects are expensive things it is true-but still the comprehensive plan is the cheapest in the end. We want Farm-architects. Not (Heaven help us !) that we want more expense in farming, or in farm buildings, but a kind of knowledge in the whole laying out of a farm, analogous to that of the 
architect who plans a building. The Landlord, the Tenant, the Bricklayer, the Carpenter, the Workman, and last not least the gaping Neighbour-each has his opinion, and gives it freely enough. The result is generally a mongrel compromise between them all. No one voice-no one plan is predominant, and by the time the whole outlay is expended, the job is half a job, and the ship is spoilt for a ha'p'orth of tar and an ounce of oakum. The extreme of cold, as well as the extreme of heat, will leave a blister on the fingers.

Five months had winged away-and the glorious spring of that eighteen hundred and thirty odd, afore dated witl such edifying minuteness, and now hanging up like a cobweb in some neglected passage of this Chronicle-had fallen into something more than summer-since the 'Wetlandshire Mereury' had typified to the world at large that a certain farm was to be let, at a certain time. ' Fourteen' applications by the first post, duly forwarded by the prompt Firm of Penn and Debbitt-(and how many more by the next-and the next-what boots it to particularize?) had been forwarded in vain. For a blight had fallen-the strangest of blights !-the 
blight of Plenty, over the sons of the soil, and before September had crisped the morning air, and the partridge-chick had found cool midday covert under the young turnip-leaf, every county journal had its broad page of ' Sales of Farming stock' set in types in which he who . ran might read-something more than met the eye.

- Fallen upon bad times! - all up with farming, I doubt, Sir!' said a muffled voice, out of a red-striped neck-warmer; joggingly: for the utterer of the sentiment was on a rough nag, not a ' good un to look at,' but he went-as an old clock does, by habit-with an ash-stick steadily going, for pendulum, on one side, and a spur peeping under the left gaiter, and steadily going too, on the other, for regulator.

__ All up with farming, I doubt!'

And the speaker threw an eye sideways to one who rode on his left, as he repeated the last words, -an eye most expressive-for with the goodnatured ' crow's foot' that nestled close up to it and seemed to tell of home-feelings and fireside memories, there was a momentary wrinkle, a peep of something well accustomed to concealment, that glanced out for an instant-telegraphing (how rapidly!) a half 
century's experience of the words ' IN THE SwEAT of thy Face shalt thou eat Bread!' Yet not complainingly: too truthfully and heart-whole for that.

No answer came. The ash-stick went on steadily: and the spur; for the tail performed the part of index-a true tell-tail, swishing and signalizing to each application of the blunt rowel upon the same spot, grown horny and resistful under its influence. The mouth that had spoken dropped into the neckwarmer again-and the kind but care-full eye looked straight forward, with its fellow, into the early morning fog that lay upon the road and fields, and dripped upon the hedges, where the gossamer had hung its tiny tissue, waiting patiently for Sunrise. Click, click, click, click, went the aggravating offside hind-shoe, for half a mile nearly, before another word was spoken.

' Any chance of its rising again, d'ye think, Sir?'

Still no answer. The question could not have applied to the Sun, for his red merry countenance was already beginning to peep, immensely large, over - - hill, like some welcome-faced friend, half behind the door, glowing with the knowledge how the heart of him, or her, who sits within will rush 
to tear away the screen that separates them. It could not be the Sun: for he is half up now, and yet no answer from that thoughtful-looking Quixote, who sits his mare as if he was riding in a dream, and had lost the power of utterance. It was strange, too; for he had been no moody companion from the time farmer Greening's trotting nag overtook him on the road: and if he had been, Mr. Greening wasn't the man to have hailed him in the merry way he did, and especially in such times: he would have gone by with the respectful, and self-respectful, morning salute of one who never intruded, nor retreated on life's highway, in the matter of companionship. But that question-What was there in it that had stopped the way-cheer of discourse, and set one of the parties thinking like an oracle? It was well that his mare happened to make a false step as he turned her from the footpath where she had been nursing her hoofs, for it made him wake up, and say, 'I'm not sure, Greening, that I can answer your question, but I can tell you how I answered one of the same sort $a$ fortnight ago, to a man who came to look at my vacant farm.

' Oh! I heerd of it, Sir, I heerd of it! They was telling of it the other night at Bogmoor: and didn't 
tell it bad either: old Dobson said the West-country gentleman stood up to his full height (and he wasn't a short un either), and says he, "Pray, Sir, how many bushels of Wheat will this farm grow to the acre?" pompous-like; and says you, drawing up queerly (and, beg pardon, you ain't a very tall un), and looking calcylating and confidential-like, " From fifteen bushels to fifty," says you, a talking to your fingers : and we all laughed, for we knew your look: and I know'd how you'd say it, and what you meant, pretty well. Yes, yes! I heerd o' that. He didn't like it, however. I think if you'd 'a' said but thirty, he'd 'a' had the farm.'

' No!'

' Not? Well, I don't know. Dobson said he seemed smartish like, and he didn't mislike the look $o$ ' the stubbles, nor the rick-yard neither. What did he say to your crop o' Swedes in the twenty-acre piece, the Brick-field-close I think you call it? Didn't he think them big enough ?'

'He didn't tell me: he couldn't, indeed: for he only looked over the hedge at them, saying that " it wasn't a Turnip farm." As he spoke to himself rather than to me, I didn't gainsay him. But as it takes me a long time to say anything smart, I ac- 
cepted that as a notice, and prepared my answer for what I foresaw was coming when we had done riding through the stubbles: and as I think his hoofs were on every acre of them, I had time enough for preparation.'

A short silence ensued. The ash-stick and the spur seemed to work less emphatically. The horses dropped into a walk: they were nearing the town of ___ which began to loom through the morning mist. The approaching termination of the ride seemed to bring the two saddles closer together.

' I think I know what you mean. I had an inkling of it before, when I heard the story from old Dobson; but I see it plainer-like now, after what you've said. You likes a man as thinks of grace afore meat,' said Mr. Greening in a sort of undertone, and looking up into the face of the other, significantly, and with a half expression of enquiry.

' You've described it more shortly and better than I could have done; you've hit the nail on the very head,' said the other.___ ' I don't know how it is, Greening, but these dark misty mornings bring some thoughts into my mind that I hardly know how to tell exactly as I feel them. But this I know, that some of the thoughts they bring make me shrink 
from the very sight of a man who looks at nothing but the Wheat stubbles. I'd as soon ride this mare straight into the knacker's yard" _-

' Lor' blesh ye, Sir!'

'Well-you understand me; it's but a young one, certainly, for that last journey; but I should feel less sin or shame in that, than in letting a farm to a man who looks at the stubbles first, and the Turnip-fields afterwards, or not at all. The knacker has an eye for horseflesh'-

- 'For the dogs'-

'Exactly! and so have some men for a farm. It does seem to me strange that all these Corn-law pamphlet-writers and law-makers should have omitted this-but I forgot-I am afraid you and I are not quite on the same bench in that question.'

'Ah! don't'e say so! I should like, uncommon, to have a bit of talk with you, though, about that. It beats me entirely when I hear tell that you ar'nt - that you go with them there Free-Tra-'

' Take care! take care!' said the other, turning quickly in his saddle, as the fore-horse of a wagonteam turned suddenly at full trot down hill from a side lane into the high-road, grazing Mr. Greening's unspurred foot with the point of the leader's 
stretcher, and bringing the whole team, and the wagon after them, rumbling round the corner, a very near shave and at the imminent risk of shooting off a sack or two of Wheat that lay not very safely on the near-side shel'-board.

'Ay! there ye go,' said Mr. Greening, rather angrily, as his hot and rough-coated nag jumped with some alacrity against the pathway out of reach of the wheels, pressing the other rider pretty close to the ditch, while the wagon passed on before them-'there you go Mr. Cropfield with your new wheat and your Straw again! I wonder how many sacks to the acre you've grown upon last year's Oat-stubble this time ! Do look at the boultings, Sir ! That's for litter for the team I suppose! He's late to market with that load; no wonder the' go so fast. Well, if it ain't enough to make an honest head ache to see that!' added the indignant farmer, in a tone of unusual sarcasm. 'That's what I call taking the eggs to market, and the hen along.'

- Wheat on an Oat-stubble !-_- He brings back manure, I suppose?'

'Ay, for the Barley-crop; or Oats again, may be: it's all the same: he counts back'ards; he begins with the grain, and ends with-no, no,-he never 
comes to the green. He says stems pay quicker than roots : and Stock's expensive; so he starts at once with the high figures-though, my life! 'tis but a low un now, for that matter. Do you think, Sir, it'll ever get up again?'

'The old question again! I'm afraid, Greening, you'd never hear out the auswer, even if I could give it. Sharp questioners are short listeners.'

'Oh! trust me for that: if you'd spare me the val'e of a half-hour's walk through those Swedes again (I should like to see how the dibb'd uns get on), I think I can take all you'll give, and ask for more.'

'Oh, you're most welcome to see the Swedes: you'll come round to the dibbing, depend on it, and when we've done there-'

'I shall come round to something else! Ah! that's capital! No, no, no!' said Mr. Greening, laughing and suddenly bending his pony's shaggy neck with a jerk of both reins towards the street that led into the cattle-fair, for they had reached the town, and the turn brought the colloquy to an end. ' Well, I shall keep you to your promise, Sir, howsomever. Please to look out for a trespasser on Monday morning! you'll be most like to catch me early. I haven't forgot your words last autumn 
about the matty - what was it - the mattytynial hours.'

'You'll be my fast prisoner to luncheon-time. Well, good day, Greening, and a good Fair !'

Ah ! those 'matutinal hours!' I repeated to myself, as Mr. Greening's good-natured face nodded away, and the ash-stick and the well-worn spur, and the click, click, click, of the hind hoof were lost up the street, towards which Nelly swerved sympathetically for a pace or two before she swung again into her usual trot, and forgot her little rough-coated companion.

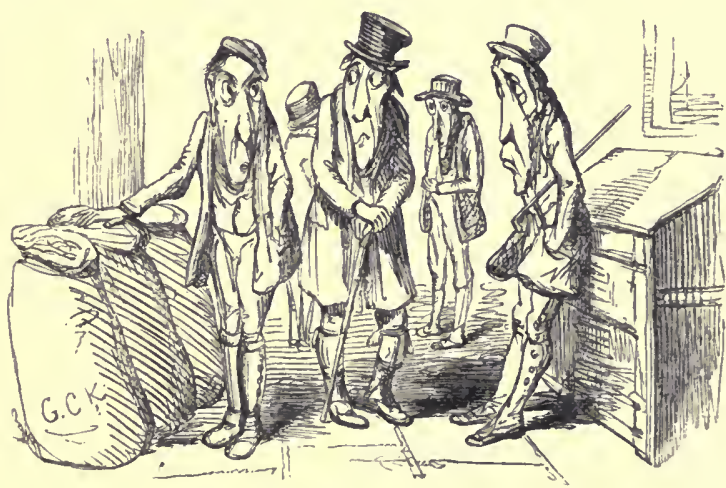

'All up with farming, I doubt!' 


\section{XVII.}

\section{A 'MATUTINAL HOUR.'}

IT requires no small experience of life, to fully realize the often heard and often repeated truth, that ' everything goes by comparison.' When the philosopher tells us that we only know the true value of a thing by the want of it, he merely reasserts this fact. We judge only by the light of contrast. A man who has lived all his life in England has no adequate conception of the English climate. Including with it that of Scotland and Ireland, it stands alone in the world-in that part of it at least which most travellers visit-the Continental world. Its sudden smiles and sudden tears are something truly hysterical. Like some fair maiden who weeps she knows not why - then stops and smiles a bit-a fickle smile-then falls to weeping again; there is no knowing when or where or how to be up to all 
her moods. She is the very April among nations. The Barometer, a tolerably steady-going guide elsewhere, she turns into a perfect laughing-stock. Fourteen times out of fifteen, it is said, she makes him play the fool. $\mathrm{He}$ is like an old Pointeralways making a dead set at a dead scent, or-at nothing:-a disap-pointer indicating that which was,-and is no longer.

Is it a vice or a virtue? It does not come for nothing. It has its meaning. It is not sent 'promiscuous-like' to worry and perplex 'us fools of Nature,' for no object or intent. In her trickiest and wildest and most fantastic frolics, Nature is full of soul, full of deepest, and aye! of most loving purpose, manward. Under hotter skies, where the flesh of beasts is not so much a food as an unhealthy stimulant to the blood, and where the cool vegetable and farinaceous diet are all that man's strength or warmth or appetite requires, 'cats and dogs' indeed do sometimes come rattling down for day's together: but they come in a pack, full cry: or in equally expressive Indian phrase, it pours 'monkeys with their mouths open' when it pours at all. But the gentle English sky alone 'rains 'Turnips:' and English Legs o' mutton, and English Roast-beef, were 
assuredly concealed behind the veil of centuries, when the first daring mariner, as old Herodotus tells us, was scared back by the 'Fog and falling feathers' from the sacred coast of Albion. Far away in the thirsty regions of the South, as sun rolled after sun, in dry and blazing sameness through the sky, unscreened by the mercy of a single cloud, I have gasped and pined for an English wetting-for one day in the most dripping covert-for the murkiest downpour-for the darkest clouds that ever gathered in gloomy council over a November day,till the very memory of it seemed like a dream too delightful to have been ever true ! And often since, when the very drainers-(and they stand the waters from above the firmanent, and under it, pretty well) - have cast up furtive eyes out of their soaking trenches to see if ' the Master budged,' giving sundry hints that 'it's a'most time to give in,' I've stood my ground for hours against the welcome fog and shower and darkness, from the sheer inward force of well-remembered contrast, determined to have it out with Nature, and come to a final arrangement-a sort of water-level with her, for having been cheated out of two or three English winters. And I sometimes think she has whispered me a 
secret, in return, about those dark and mis-abused November days - as she is prone to do to those who persevere with her-which have made me prize her, and them, and the land they love and lave, the better; and feel that there is a rough poetry and truth in its iron-grey mists and showers, which have made true of the Farmer what was said of the good and brave man under life's trials :-

He does not run all helter-skelter

To seek a temporary shelter;

Nor does he fume and fret and foam

Because he's distant far from home;

For well he knows, each trouble past,

He's sure to find a HoMe-at last!

It was to some such inward thought I was indebted,-and as a faithful chronicler I ought to tell it,-for the courage with which, after tossing off the blankets an hour earlier than usual, I threw my window open to-such a Monday Morning! prefalsified by the brighest stars and clearest sky that ever closed the day of Christian Rest.

One universal soaking drizzle seemed to have taken secure possession of earth, sky, and the day. The small rain gathering on the trees dripped larger from leaf to leaf, falling in the most hopeless and 
measured way, taking it easy as though for a week's continuance, and no hurry at all about the matter. A single red streak, much too red, lay along one part of the horizon, like a long-drawn smile, pregnant with malicious warning for the afternoon, and killing the faint hope that clings to 'twelve o' clock' as an alterative.

Now for my promised trespasser among the Swedes! No need for man-traps to-day in that quarter, though I, preparing to met the foe, with a pair of gaiters that seemed made for the Slough of Despond. The turf-ground wheezed and yielded under every footstep, plainly dating back the rain to an early hour of the night, as I made my way to the field; and as my eye scanned its whole space over, the victory of the 'early-bird' seemed assured - when suddenly close to me, from the other side of the hedge, just where the master-drain opened out,-came a ringing 'Good-morning, Sir!' into my very ear, and $\mathrm{Mr}$. Greening, rising from the bent posture in which he had been scrutinizing the drain, looked with mischievous unconcern the victory he had promised, and accomplished.

' Not deep enough!' quoth he; laconically.

'Which!' 
' $\mathrm{Oh}$-the Drain-not you; and as for' me, I was deep enough! You thought the drop o' rain had stopped me: no, no! I like a rainy day, to see this sort o' land. These are laid at three foot! Four's better.'

'You really think so?'

'I'm sure of it! But I thought you was all for the deep drain? I heerd so, long afore I tried it.'

'And that's why these were laid at three. This lower part, up to yonder oak-tree, is the first field I drained: and if you had seen the work I had, to get down three feet-_

' Oh! ay, ay! I remember now you mention it. Well, I like the four-foot. But not too wide, mind! I'll allow any man to tell me how deep to drain, if he'll leave me, on my own sile, to say the width. It's a pity to spare a row or two o' tiles, to run a risk.'

'Well: this is three feet, by twenty-one in width: down the old furrows, in fact. And the worst of it is, it drains extremely well.'

" "The best," you mean?'

"The worst!-The good done by the shallow drain has been, in practice, the longest enemy of the 
deep one. A man who finds his field improved by the shallow drain, holds that as a fact. When you tell him that double the depth would have more than doubled the improvement, he treats that as a - a theory. A DREADFUL thing, that Theory! I wonder how many who use the word-ab-use it rather-know the meaning of it. But what say you to the dibbing?'

- Well, they're very reglar: hardly one miss'd. But I don't like to see 'em quite so high out of the ground. I fancy it makes a tough skin, and a bitter one. The drilled uns don't look so reglar, but they seem to hold the ground better. How's it done?'

'By the acre; after the first ridging-up, unmanured; a boy goes first, pressing the dib in with his foot. You shall see it presently; it is held by both hands at the top, with a spoke out for the foot, just above the ball of the dibber, to mark the next distance as its point meets the ground, in drawing it out, sideways, in going along. The hole takes about a half-pint-more it should be. The women follow with the manure in a sort of hopper, toss a can-full in, which fills the hole, and drop the seed in. It is done very quickly; bnt the mixing of the manure 
is the great point. You must come and see it done.'

' I should like it better for light soils. I doubt its answering so well on this kind,' said Mr. Greening, thoughtfully, and poking his stout stick under a turnip which rose very slowly and reluctantly out of its bed. 'What is to be done, Sir, with these Clay Siles !-I like 'em-I own I like the strong sile best-but what's the use o' liking what don't pay? The labour's double: everything's double expense on 'em, and the time less to do it in: for drain 'em how you will, you can not make winter work on 'em, as you can upon the light. Now don't you confess that?'

'Ah: thereby hangs a long tale! Chemistry on the Light soils-Mechanics on the Clays! When will that great 'Chapter the Second' begin to open? We haven't quite found out everything yet, Greening! There's something to come, I suspect, upon the Clays, that will startle you and me-wise as we are-some day. "A thing to dream of-not to tell." But come-you must put the Beans, meanwhile, against the Barley.'

'Well, that's true: but that won't match it, I'm afeared; not by a great deal. Here's Wheat now 
down at five-and-thirty! Egad, I can't give it away ! and I remember my poor old father, -and that's five-and-twenty year ago, in the war-time,-as the bushel o' Wheat dropped into the sack, saying to me, "There's a guinea, Ben!" and "There's another!" as the next fell in; and so it went on. That was farming, that was! I'm blest if I don't think they got their own price, and ours along!'

'You've hit the very truth, I do believe: they forgot to take their share of the per contra, when the war was over. They made a wiLl, bequeathing that to us; for that, I imagine, will be the end of it.'

'What's the use of making a Will, when you've nothing to leave? They should have left us another war, and short harvests ; that 'ould have done better than any laws, I fancy, to keep up prices.'

' Postponed the change, perhaps; not prevented it: it was inevitable some day. The fairer course would have been to have accepted it when it fell due, and begun afresh, with some of those guineas in hand that you speak of.'

- Well: it has beenjbut a crumbling wall for twenty years, ever since the $W$ ar ended, with now and then a bit of a check, in spite of all the laws to prevent 
it: and these three fair harvests have laid us now as flat as we could lie, if the worst had come to the worst.'

' It seems then that to inherit a falling market is worse than to be born into a low one. You're right. The latter admits of hope; the other is continued mis-calculation, and disappointment:-and something worse than either.'

'And what's that?'

'I won't tell you till after breakfast! Come, you old Grumbler, it's the driest subject in Creation, and will take you three cups of hot coffee to get it down. You shan't come into my Sanctum with those boots-boots! why, they're like barges, sunk to water's-edge! You remind me of a certain Mr. Demos of a place called Athens, a very noted gentleman in days by-gone-

$$
\begin{aligned}
& \text { 'T 'T was ask'd through all the quarter, } \\
& \text { 'Came you in Boots, sir, or in Boats - } \\
& \text { By Land, sir, or by Water?' * }
\end{aligned}
$$

off with'em! they shall be cooked, under the mutton chops, and come in again with the muffins! You're in close custody ; so peel off that patrimonial-looking

* Aristophanes, Equites, 321. The translation of the pun is Mitchell's. 
great-coat, and send it after the boots. Why-it's as heavy as-those same guineas! I'll be bound the lining's stuffed with 'em!' [Mr. G. eyed it over, and shook his head, smiling grotesquely.] "Well! come along-you shall abuse the "Furriners" and Free-traders over the first two cups, and we'll drink " Better prices for ' 36 !" over the third.'

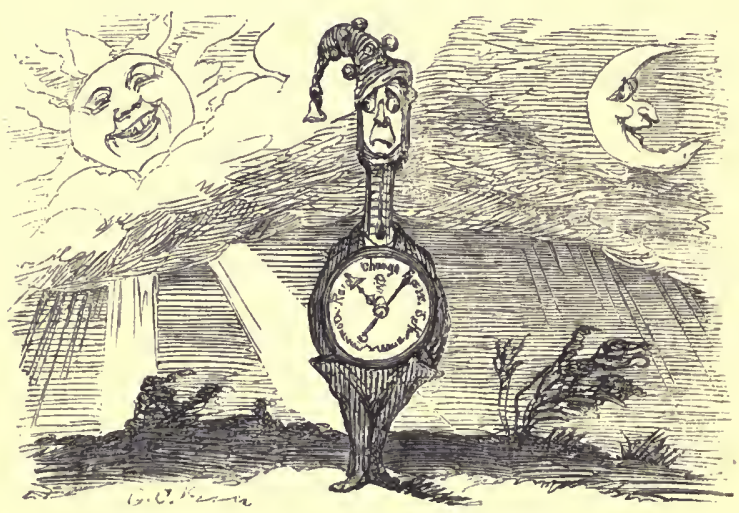

'Inducating that which was, and is no longer.' 


\section{XVIII.}

\section{'TALPA' LOQUITUR.}

Arrovg the various experiences which the much more social Agriculture of the last twenty years has brought, (for a great change has come over us in that particular since-well-never mind how long ago I was going to say,-) there is none which has struck me more than that part of its philosophy which consists in the operation of mind upon mind. That of 'mind upon matter' is not a very new subject: we see it every day,-and hear of it too, till it is something tiresome: just now we are on a different theme, and a less trodden: 'mind upon mind' is our point at present, and perhaps the more important of the two, after all. I was going to say that in a pretty long and intimate experience of a rather curious soil to deal with, and to which never did man, horse, or implement deny the epithet 'stiff,'-I too, like them, have had my own dumb reflections, and not the least emphatic of these have grown out of the everyday phenomena of mind acting upon mind. You tell a man something 
to-day, or express an opinion, or assert a fact, about a thing which he has perhaps never noticed, or never heard, before; he smiles, starts, shakes his head, or delivers himself in some other way, for the ways are various in which men 'behave' (as the chemists call it) under the infiltration of a new idea. Whatever the mode may be, one thing you may be sure of, that in the grunt, the smile, the laugh perhaps, in fact whatever it may be that meets you, the attitude of mind betokened is that of-dissent. I am far from complaining of it: some of my best hands have given me infinitely the most mental gravelling in this respect. But what I do complain of, and want to know where to apply for remedy (since the Law tells us that for every Wrong there lies one) - is that these same hard-headed fellows, Workmen, Neighbours, Friends, Kind-advisers, or whatever other relation they may hold,-six, twelve, or eighteen months afterwards, coolly come to me, and with all that air of profound thought that becomes a man of reflective character, down-calving as one may say with something intensely wise, announce to me in language of their own, the very thing which I at such time back suffered a small martyrdom in the vain endeavour to urge upon them ! 
I know not whether other 'employers of labour' have felt this sort of paulo-post-futurum experience as $I$ have done. But I suspect so ; for every man is (and it is comforting to think so) only the unit of $a$ class. It is difficult to study for years the character of a soil, without learning something of the character of those employed upon, aye and even of those who visit, it.' And this has been my especial grievance, and one which Time, the 'smooth-handed god,' has increased, not lightened. People who derided my ' improvements,' laughed at my 'deep' drains, bewept my grubbed-up ash-stumps, mourned over my obliterated hedgerows, turned up noses at my tank, listened with mock-gravity to my 'mysterious' remarks about the 'ecomony of warmth' as cheaper than the 'equivalent in food,'-and a great many other things that it would take an inventory to tell, -do now come and preach to me such admirable sermons on my poor old antiquated texts, that I should really begin, as other worthies have done before me, to doubt my own identity,-but for a little store laid by in a corner, of the capital I began with, and which I commend again to all beginnersnamely, of philosophy.

'The mind,' says an old author, 'like the body, 
must digest before it can 'assimilate.' The hungry dog bites your fingers as he takes your morsel: but the food becomes flesh, and the want is forgotten,with the giver.'

And so I have found it: and so, no doubt, have others. No sooner is a new thought imparted, than it sets up for itself, and denies its pedigree. ' Why, that is exactly what $I$ told you three years ago, when you came-\&c.___' you feel on the point of rapping out, struck with amazement.

Spare your breath! and your reproach. He cannot remember anything but what he now knows. He forgets that he ever thought otherwise! Tell him, now, something new, and you will see again the same derisive smile, the same look of idle wonder, aye of contempt, at your fanciful, ideal, 'theoretic' notions: and twice twelvemonths hence, when your idea has taken root and become a fact, the scene of to-day will be acted over again. Then go to your Library,-large or small,-and look back over the history of the world; and you will see that the annals of human invention and discovery are the true history of Martyrdom, and that to be stoned by his .own generation, and worshipped by the next, is at once the penalty of human pioneership, and the 
reiterated monument of human folly, dotting the road, like milestones.

It is very fine, no doubt, to connect one's own small-scale improvements, after this fashion, with the history of the Great aud Dead, to whom life was one conflict with ridicule and contempt-a history the most affectingly interesting-perhaps the most important that is left to us;-but after all, the grandeur or pettiness of the scale does not alter the argument. And when I had listened for half an hour to Mr. Greening discoursing of Guano and Superphosphate, in as easy and as matter-of-fact a style as if he had regularly carted them out of his farm-yard on to the turnips any time this fifty years (though he still called it Gu-anner and would not have it at any price as a word of two syllables), I could not help mentally amusing myself with thinking of the time when he used to poke every imaginable jocularity at me for 'sowing the sawdust,' 'wheelbarrow farming,' ' pocket-dungcarts,'-and a whole heap of good sayings which, duly noted down on my part, made my chronicle of that date a complete glossary of farm-witticisms: and curious it was to see how the memory of former incredulities had passed away from him. My deepest drains were no 
longer deep: my largest fields no longer ' to' big for the farm.' But Greening was a true improver notwithstanding. $\mathrm{He}$ baptized every new-born notion with a jest, but he watched its growth and adopted each youngster in succession, and so heartily and practically withal, that they seldom got into his hands without thriving better after all than they had done in mine.

Ye ardent Go-aheads ! who expect every new argument to tell at once,--every intellect to yield at the first onset, every new plan to be tried by everybody,-learn to wait: and you will find that there is much more chance of your notion being overtaken than overlooked, much more likelihood of your having to re-claim than to re-assert a single hint that was ever good for anything. The seed may seem a long time buried, but if it have any vitality in it, it is germinating where you little think, and will fructify when you least expect, and with a produce you had never dreamt of. And when you come again and say 'this is mine!' do not be surprised if shouts of louder laughter greet you than even befell your first announcement of it.

I had time to think all this: for my guest, like a shrewd bargainer, as he was, gave a little fling to the 
general discourse before he came to business. In fact he had the true diplomatic tact of always making the business come of itself. "Well then! Here's "Better Prices for thirty-six!" and that's with all my heart, and no mistake,' said he, 'topping up,' with a final cup of Coffee, that healthiest and purest of mortal meals, a plain but hearty breakfast. 'And now, Sir,-when are we to see 'em!' he added, giving his chair a shove sideways, slapping his hands on his knees, and facing me, like a lion refreshed: ' for it's my notion we never shall again!'

'And then - -?'

'Why the farmers 'll be ruined, and the land 'Il go out of cultivation.'

'And the Landlords —? ?

'Will follow, of course. They depend upon the Farmers, and the farmers on the land.'

'And the land on the price of Wheat?'

'Surely.'

'Indeed! Tell me this, Greening: have rents risen or fallen since the War?'

' Risen, certainly ; and too much, to my thinking.'

'And the price of Wheat has been falling: from eighty or ninety shillings a quarter to forty or fifty, 
as we remarked this morning. Rents rising, and prices falling !'

'Aye! and the farmer's business getting wuss every year. 'Tisn't like what it used to be.'

'Just so! and competition keeping up the rents notwithstanding!'

' Aye ! that Competition! It didn't use to be so. And what is it after all? No sooner a Farm's vacant than a hundred fellows come yelping after it like a pack-o'-hounds, offering a high rent, and not one of 'em perhaps with the valye of a team o' horses of his own, scarce: and when they get in, what do they do? Crop every field that 'll bear a crop, sell all off for a few years, and then leave it clean beggared, and the landlord without his last year's rent p'rhaps.'

' No Turnips - they take no root, Greening !'

'Turnips! they've no stock to give 'em to ! What's the use o' them growing Turnips? that's not their sort o' business.'

' And they outbid the honest cultivator, and the skilful one: in fact they can afford to do so, because they can afford to rob: just as though a man offered you a higher rent for your house, meaning to sell off the furniture.' 
' That's just it: that's just what it is, surely.'

' And the higher the price Wheat is kept at, the better it pays,- - the greater the premium, in fact, on that kind of 'farming,'- - the higher the shamrents offered over the head of the fair tenant,- the smaller the inducement to steady and fair cultivation, - the greater the breadth of Wheat unfairly grown, - the greater the consequent glut upon the cornmarket, and the injury done to the honest grower who has earned one large grain crop by growing roots and feeding plenty of stock, instead of raking the land by frequent and diminishing crops with no stock at all. Is that to your liking? Will you pray that the inducement may continue of that style of farming? of that style of competition? of that style of rent-raising, that ends in ruin to the beggared land, the .ignorant landlord, the foolish tenant, and the defrauded labourer?'

Mr. Greening looked thoughtful, - 'Well there's something in that, perhaps; but how's it to be stopped? How's them sort o' farmers to be put an end to?'

Now it was the other's turn to be a lion. So the savage beast sat right opposite to poor Greening, and glaring fiercely in his face growled out-' Now 
look at me like a man-don't faint-and I'll tell you.-By serving them as you do the Rats when you take the Ricks away! Starving 'em out! There's no other way! They'll starve you if you don't starve them. Their food-their only food is -ever has been-the premium price-the disproportionate value of the grain-crop. TaKE AWAY тhat Bauble!' quoth farmer Oliver-the Protector.

There was an 'awful pause.' Mr. Greening was looking into the fire. One would think there was something written in the live embers which he was trying to decipher - so hard he looked at it-' Ah ! I've thought o' that!' he slowly muttered at last, as if to himself; - Kill or cure! But that's " kill first and cure afterwards.",

- Kill the proud flesh to cure the sound. Yes: cruel work, no doubt, at any time; but crueller when done at the wrong one.'

'When's that?'

" The moment when it will be done; as surely as effect follows cause! Does it need a ghost to tell us that that time will be a time of scarcity-a famine perhaps, or a fancied one? Then it will be done, and done in a hurry too! And then - 
What comes after a famine, Greening? What is the recoil of Scarcity? - Abundance-very true :then will be the tug of war, then! for good and bad together. "A cruel brute, this Lion," we shall say! and yet he pastures on the cruellest of all : he cracks the bones of the true blood-suckers; and "when it's bad weather for thieves," they say, "the true man may sleep the sounder," let the rain rattle on his corn-stack how it may. " Let Mr. Lion roar again,' you will say, when you've seen the end. Even your tiny Mole is a ruthless beast of the field-to slugs, and snails, and caterpillars, and such land-sucking fry-a fierce subnavigator, in his way: but his track turns up some pretty cultivation; it only wants spreading,_far and wide! It's not so wise to throttle him as you think. I grieve to see him hanging gibbeted-his clever paddles stopt, by cruel ignorance. For he is your only granulation-master; he taught us drainage--and sub-cultivation-and we shall learn of him another, and a greater lesson, some day, and call him a prophet- when we've done hanging him-and have got some speculation in our own eyes (whose sense is shut at present), instead of saying he can't see. Day and Night: 
He has the better right to say so of us!-But as for this price-of-corn question-this grain crop versus Green crop,- - trust me, Nature has her true Proportions - and is pretty rigorous in maintaining them: and you cannot throw them out of gear, but she'll be down upon you somewhere. Green-cro' versus Grain-crop! Which would you show favour to, if either? the man who comes to make an investment-to earn a crop, knowing the cost, or the spoiler that comes to take one, counting nothing?him that comes to sow before he reaps, or him that comes to reap before he sows? Do you remember what I said about "Grace before meat?",

' Yes, yes! I remember it, I've thought of it too, though I never did in that way 'xactly before.-I see your meaning, now. But-but-about theWhat was it you said about the Rents?'

'Ah! the core! the vital point-isn't it? touch it tenderly for the life of you !'

'But will they fall?'

: Will they stop rising a bit? Catch that fish first. Get him well on the hook: land him carefully; and you won't have quite an empty basket, I can tell you. I'm not sure if it won't take care of itself afterwards. Which farm pays the best rent, 
even now, the one where the highest was promisedor the other?'

$\mathrm{Mr}$. Greening drew in his lips and shook his head. 'Let the Landlords answer that. "'Taint all gold that glitters.",

'True: so for those that can't distinguish, a pure currency were the greater blessing, eh?'

'There 'll be less of it, I'm thinking,' said Mr. Greening, ' if it comes to that. But that aint all. There's them Clay Siles. We haven't done with them yet.'

' We haven't begun with 'em! We know nothing about them! almost absolutely nothing! We know that they are stiff to the plough and sticky to the flock; positive to the Bean, and negative to Barley; costly to drain, and, without it, profitless to farm. We blunder on, with just these two or three negative dogmas on our tongues, and are satisfied to think them knowledge enough. The truth is, we have everything to learn about them. I say again we haven't begun with 'em! But come, I'm out of breath. " After breakfast sit awhile,"-we mustn't ride the old maxim to death. Let's go and look at them: I can give you your choice-Red, blue, yellow, and white, and every one with a different 
temper for every month of the year! The man that can tell what is to be done with them-'

'He's the "coming man," I suppose,' said Mr. Greening, laughing, and beginning to pull on his great coat; ' he must be able to mix Fire and Water first, I'm thinking !'

'And make Steam?'-said the other.

Mr. Greening turned short round at the answer, as he was going to the door, and looked a moment fixedly at the speaker. Both smiled: but there was a difference in the smiles. And they walked out together.

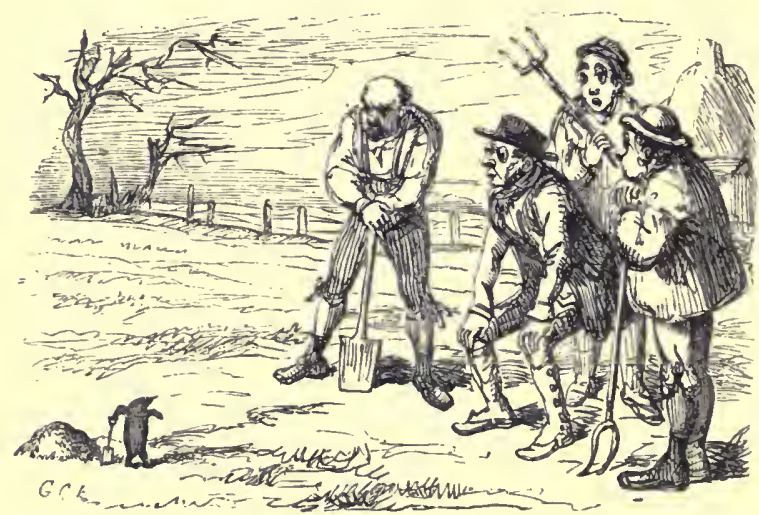

'We sk all learn of bim arother, and a greater lesson, scrue day.' 


\section{XIX.}

\section{'THE 'POWERS' 'THAT BE.}

THE concluding words of the conversation which had taken place between my worthy guest and myself over the breakfast table, gave us both an inclination to go and look at the ploughing. A Wheat stubble which had just been drained was being broken up for the next year's Turnip fallow. It was a stiff and rather thin soil, which had, to my long remembrance, been year after year suffering a continual loss, of that kind denoted by a deposit of fine sand at the bottom of each furrow, against the lower headland, from the silting away of the lighter particles of soil with the surface water that ran down them. I used never to look at it without asking myself ' How many hundred years has this been geing on? and what must be the amount of deterioration of texture (to say nothing of loss of manure), 
which this field has suffered in the aggregate? Query-would it be as stiff a soil as it has now the reputation of, if it had not always been parting with its sand by this continual process of superficial scraping?' When $\mathrm{I}$ came to drain it, $\mathrm{I}$ found that my suspicion was correct. Every here and there the subsoil was chequered by little 'pots' of pure sand, embedded in red clay, and so full of water that the drainer was obliged to tap them carefully to prevent large masses breaking off and rushing down with the fluid that burst out of them when the sides were cut through. The effect of the drainage was already most remarkable. The workmen called it 'beautiful;' and though nothing can present a more dreary look than a fresh drained field with all the cold varieties of subsoil lying exposed along the lines of the drains, I could not help feeling the truth of the expression applied as it was prospectively rather than to the actual scene before the eye. It was ' beautiful' in the same sense that many a rough-looking act, and many a painful soul-subduing thought, and many a rainy day of life's adversities, is 'beautiful " -by its consequences : and I always liked the word, so pregnant with faith in what is unseen except by the mental eye that 'views the Future in the In- 
stant.' Inexperience or ignorance would have called it intensely ugly, and would have preferred the previous smooth surface of the field, dank, cold, and intractable as it was. What a pleasant effect upon the broad field of society it would have, if a few furrow-tiles could undermine some of the cold stiff surfaces one meets with here and there, through which nothing penetrates-in which no gentle plant takes root-while the lighter and better particles Nature originally gave, keep silting away, as life advances, leaving nothing but a hard and chilly surface, growing colder and more impassive every day, to all the genial influences which shower warmth upon the heart that will but expand to and accept them.

'Well! you are a-going deep to be sure!'- said Mr. Greening, following the fresh-turned furrow, and picking up an antediluvian lump of subsoil now and then, and crushing it between his fingers. ' Why there's plenty of sand here: this 'll be mild enough for anything presently; you don't call this a stiff soil?'

' It has lain like a stubborn brute that wouldn't rise, for work or play, ever since I have known it. It won't know itself next year! It has never borne 
Turnip or Barley, since the Flood-which, in fact, it has never recovered, I suppose, till the drainingtools have bled it in this way. How little one can say what a soil is, till it is drained!'

'It does one's heart good to look at it now, however,' replied Mr. Greening ; ' doesn't it make you happy-like to see this sort of change, and feel that you have done it? it does me.'

'So happy, that at the end of a winter's day of draining-work I have spent hours of delicious idle reverie, with the Lamp wasting beside me as $I$ sat alone, dreaming the day's work over again; seeing, with closed eyes, the long-pent-up poison oozing away down its narrow channels,--poison no longer! and thinking of the future showers that will percolate and filter through the loosened soil and subsoil three or four feet deep, like some freed and gladdened thing, doing its generous Maker's bidding. I hardly know how to describe the sense of high privilege the thought brings with it-of being allowed humbly to aid, as it were, in Nature's glorious development. I know of no pleasure that surpasses it-or should surpass it-except one-except oneexcept ONE!'

'Goodness help us! why that's three!-And 
what may it be, after all, that lifts the knocker so many times for one visitor?'

' Look here, Greening! do you see that poor fellow cracking his whip over the horses in that lounging devil-may-care fashion? It's his first year at plough: he was 'kipping craows' for the last two or three. Isn't that a proper amusement for a thing with a human skull, and a real live human brain inside it? That's a promoted scare-crow ! Doesn't he loook happy?'

'Well ! he's a right to do. He's doing his duty, isn't he, as well as you and me! You can't do without him?'

'Ah! yes,-yes! that's the answer. He's a machine-, driving a machine.'

'Well-no-not exactly that, neither. They tell me a plough aint a machine. Come, I have you there for once, however! A plough's only a tool.'

'True, true: a tool worked by horses, and dragging a man after it. You never spoke plainer truth, Greening! And here we are somewhere near the middle of the nineteenth century, and talk of agricultural improvements! It shames me to think of it.' 
' What, ashamed o' the Plough! O dear, dear! Well, I aint, and never was, nor never shall be, neither, that's more.'

' Too much, a little. How do you know you never will be?'

' Not, however, till something — Oh, ho! I know now what you're after. You're a-driving now! Ay, ay! Now I think of it-they tell me you're always a-driving somehow against the plough. Well, what's the matter with it? So long as it's a good un, mind! Come now, I should like to hear from your own lips what you've got to say agin' it. I can not understand them books, so it's no use trying; and I do try, that's a fact; but as sure as I get half-way down a page I go to sleep. A lot o' Chemistry and stuff! I'll back common sense agin' Chemistry any day. But I should like just to hear you on a bit about the plough-I think I could understand that; but you must please keep the words close-cropp'd, you know,-no raspers! A farmer's words should be like his hedges, I always think,-plain and short and smooth-like, and not too many of 'em! and then they may help to 'fill the bushel 'after all, p'rhaps. But about the plough -beg pardon-you was a-saying something___-' 
'No, no! go on, Greening! I like to hear you.'

'Well, I've done, i' faith! clean out, like. I'm your listener for half an hour-more, if you can spare it.'

'Can you promise that? I've had many a useful hint from you-Could you sit and listen to my nonsense now, just for half an hour, straight on end -no snoring allowed, mind! - and what if I were to read it, instead of speaking? Now don't look frightened! it isn't a book-only a few sheets of paper poked away in a drawer somewhere, and scribbled over: fancy it a long letter from your ever affectionate brother beyond the sea, or a notice from your landlord that he's going to lower your rent, and giving all his reasons for it. Don't you think you could keep your eyes open?'

"Well, I think I could! But I hope it's in "words o' two syllables:" that's all I bargain for; and I'm your man now. No time like present time!'

A few short steps homewards; a long rummaging over a drawer of papers; a great deal of settling down comfortably in arm-chairs; and, I'm afraid, a couple of cigars, followed this sudden resolution; and Mr. Greening looked wide awake, as the other, 
casting his eye rapidly down the pages of a manuscript, which looked as if a swarm of spiders had crept out of the ink-pot and been playing at leapfrog over the paper,-cleared his throat and began reading his

\section{'Private Notions on Cultivation.'}

"There are three kinds of "power" employed by man. The first is manual power, the second is animal power, and the third and most recent is mechanical power. Each has its own peculiar mode of action; and refuses to adopt that of either of the others. The power of a man, from his erect figure, and the direction of his spine, acts most effectively in lifting. When he works at a winch, his greatest force is in lifting the handle from its lowest point in the circle, to about half-way up. For the same reason, in pulling at the oar, or towing a barge, he inclines his figure as much as possible in a direction perpendicular to the stress. In digging, he lifts the soil more than the plough does, and in pressing the spade into the ground he still employs perpendicular force, limited only by his weight. Manual labour is in fact most powerful in perpendicular action. 
'But when a man gives up the spade, the hoe, or the flail, and employs his horse to cultivate or thresh for him, a new direction of applied power takes place. The back-bone of the quadruped is horizontal, not perpendicular, to the ground: and the adaptation of the power must be accordingly. The horse cannot lift and press the implement of cultivation, but he can draw it along; so the spade and the hoe are turned into tools of draught, and are drawn through the soil, raising it with the spiral-wedgelike action of the plough, very damaging to the subsoil upon which the whole stress and hardening pressure come, but cheap and expeditious compared with the spade, so far as regards the mere inversion, or partial inversion, of the soil ; though doing little towards its cultivation. Again, in threshing, the application of the horse's power must still be horizontal, like his figure, and his work be done by lateral pulling. The direction of animal power, in fact, is horizontal: and horizontal draught is the only form in which it can be applied.*

'But draught is not necessary to cultivation, nor is

* Except perhaps in the case of a turnspit dog, or a squirrel in its revolving cage, where it is applied to generate circular. motion. 
it even desirable. The plough, the harrows, the scuffler, and the horse-hoe, are but processes rendered necessary by the only possible mode of applying horse-power to the turning and breaking of the soil.

'Mechanical power is totally different: and has no more business to be applied to the plough, than a horse to a spade. When horses have been taught to dig, the steam-engine may perhaps be taught to plough; but nothing will be gained by either; because it is NOT THEIR MODE OF ACTION, respectively. The laws of Matter and of Motion are imperative; and pay no service to the wall-eyed prejudice of man. Mechanical power has many modes of action; but whether wind, or water, or steam, be the driving agent, the favourite motion is the vertically-circular, or ' rotatory.' The horizontal water-wheel is good, but extravagant, and of limited application; but it is worth mention as an exception. Where steam is employed, rotatory action is almost universal. Instance the steam-paddle, the screw-propeller, the common fly-wheel, the locomotive driving-wheel, the circular saw, the drum of the threshing-machine, the steam-pump, and many others that will occur to the recollection. When 
we plough the sea, by steam, we do it with the blades of a circular paddle: why not the earth? When we cut wood into saw-dust by steam, we do it with the revolving teeth of a circular saw : why not the clod into soil as fine, by the same mode of action?

' What has the laborious dragging of a plough to do with steam-mechanism, whose mode of action lies in rapid revolution, which applied behind your locomotive (which must travel forward on the hard soil), could cut a trench a foot deep, and with its casehardened tines, rasp away the soil from the land-side to any pattern of fineness, as easily as a saw can cut a board, taking a moderate bite five or six feet wide as it goes

" "Gently over the stones!"' shouted Mr. Greening as the sudden crash of a fallen tumbler awoke him up, and the opening door announced the entry of luncheon-6" a bite six feet wide!" my heart! who was it took that, Sir? What a happy-tight he must have had! What, luncheon a'ready ! well, it's uncommon interesting, I'm sure! Why you'll be quite an Inventor! It's for all the world like what my little girl reads out to me o' nights from her* 
"Life o" Columbus"-somewhere in the beginning part, where he talks to himself so, till they all thought him out of his wits. I'm blest if it aint just like Columbus, as diskivered America!-You ought to take a pattern out, Sir.'

' Did Columbus take out a patent, Greening?'

' Oh my! that's capital! a pattern for America! IVell, that is a good un, however; no, no, I guess his diskivery was a little too big for a pattern _-_ Wide as a world and broad as 'umanity," as our parson says-No, no! he died quite the wrong side o' money-making now I think of it.-But I wish you'd a' talked it, now, instead o' reading : for somehow the soft back of this chair o' yourn, and thatwhat was it-piping-Dickler-my heart! what a word that was; it sent me right off wool-gathering -I knew it would! I just shut my eyes to think it over a bit-and I was off like a shot. What is the use o' them long words - they're just for all the world like the Spanish onions,--ha'n't half as much flavour in 'em as the little uns. That's what comes o' your travelling abroad now! Blesh ye, them Romans and Antidaluvians as you 'a' been amongst, don't know no more about farming than a lot o' cockney tailors, for all their long words. Now do just 
try, Sir, if you can't slice it up like, into small uns, so that a plain man can understand it_-

- And make it so plain that every one as he reads shall think he knew it before. Well-comewe'll talk it over in plain English after luncheon.'

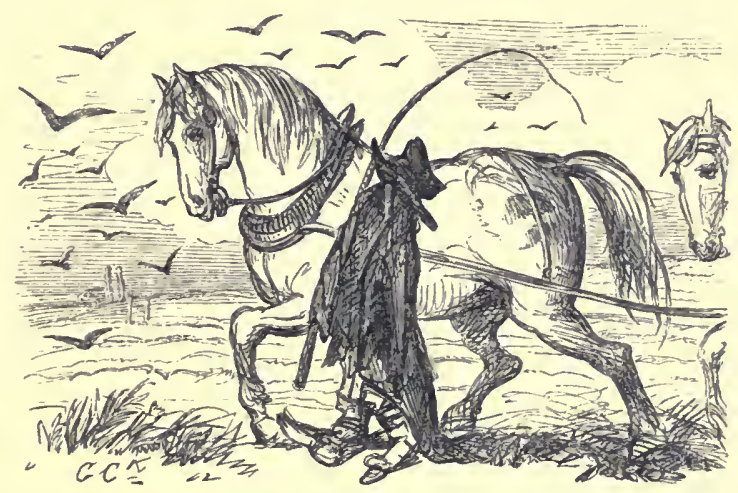

"It's his first year at plough: he was "kipping craows" for the last two or three.' 


\section{XX. \\ THE PLAIN 'ENGLISH' OF IT.}

Wнат a curious, complicate, half-interesting halfprovoking problem is that presented by a shrewd, practical, experienced, and well-poised mind, without education! Of course I am not speaking of that education which every active mind, learned or unlearned, is daily picking up, from the first entrance into real life, till ' the night cometh when no man can work ; but that particular appropriation of certain early years to the school-room process (even such as it still is !) by which the mind is kneaded, and tempered, and subdued, during its only plastic age, into that peculiar tilth and texture, whose after-benefit is known, not by the mere acquisition of the prescribed formulæ and rudiments of knowledge, but chiefly by the having learnt the art of learning. If the knowledge that is carried away from school or college 
were all, Heaven help our First-class-men and Seniorwranglers! But if you want to know the real value and blessing of that tedious operation that seems to cut up our early liberties, for so many years, into ' morning and evening lessons,' watch the efforts of a naturally strong and gifted mind, struggling in the after-years of life against the stereotyped effects of early neglect.

There is no class, probably, in society, amongst whom more striking instances of this occur than the agricultural : none, perhaps, in which there is less of what is called 'book-learning;' none, certainly, in which there is more of natural shrewdness, and a sort of furtive observation which shrinks from being itself observed; paying the tribute of a kind of secret intelligence and appreciation to qualifications and attainments which it never affects, and, to the careless eye, appears to despise. But it discriminates nicely. For Nature is a schoolmaster that teaches without spelling-books. To the husbandman, toiling early and late, her rede goeth forth, but it is not speech nor language: it inwardly informs: and as the teacher teaches, so the scholar learns.

Such was the case with my good friend $\mathrm{Mr}$. Greening; for I have tried to delineate his character, which was an admirable type of a class still 
little understood, and caring little to be so. I knew that he would be 'asleep' during my sermon 'on cultivation :' and he knew that I knew it; and would not have been awake under the infliction of so many long words for his life and character's sake. But to sleep without an eye or ear left for sentry-duty-that was far from Benjamin Greening. And I, for my part, was satisfied with my audience ; the more so, because I knew that I should find in him an objector, who would not fail to start every difficulty which feigned. ignorance, or practical knowledge, was likely to suggest.

Mr. Greening, however, was taken with a long fit of silence. Luncheon came and went; and that preoccupying subject he discussed amply and seriatim in all its branches : but I could see that my dose was not inoperative. The vindication of his old friend the Plough was hot within him, the while; struggling only with a curiosity to hear the translation into plain English that I had promised him; and which, he knew, would open plenty of points of attack more assailable than the compact and synthetical phalanx of long words he had interrupted so opportunely at ' the stones.' 
'So we're not to have a Steam Plough, then, after all-eh, Sir?' he at last began. 'Well, I've heerd talk of it so long that I hardly know whether I'm glad or sorry. But, lor' blesh ye, you go too fast: the Plough's too old a stager to be got rid of that way. Steam I do suppose it will be some day : there I suppose you're right enough. But if we're to wait till this what-d'ye-call-it, French-revolution sort of thing,-well-I beg pardon-this merry-go-round Conundrum o' yours [Well, well! whatever it is, then] is brought to pass, - why it's like waiting for two things instead o' one. No, no! ploughing it must be : it is, however, a'ready! for I hear talk o' one or two people as are trying it on. There's some lord, I forget his name, has written a book all about it, with a picture a yard long, where it's all at work as nice as can be ; an engine at each end, and the ploughs a-drawing away in the middle. He's afore you entirely; for there it is, actshally a-ploughing with common ploughs - in the book.'

' Listen to me, you old perversity. I have seen that "book," as you call it. The pamphlet reached me long before you saw it; but not till long after the idea it portrays had been as familiar as an old family 
picture to my mind's eye, and banished, in its turn, before ever engraver's tool had given it outward form and semblance. If ploughing were ever done by steam, that were no doubt an obvious way, and as good a way as any. But I hold it to be an idea fundamentally erroneous to attempt to combine steammachinery with the plough; and record my conviction, that until the idea of the plough, and, in a word, of all Draught-cultivation is utterly abandoned, no effective progress will be made in the application of Steam to the tilling of the earth. I repeat that "ploughing" is a mere contrivance for applying animal power to tillage. Get out of animal power and you leave "ploughing" behind altogether. Get into steampower, and you have no more to do with the plough, than a Horse has to do with a spade. It is no essential whatever of cultivation that it should be done by the traction of the implement. Spade-work is perpendicular. Horse-work is horizontal. Machine-work is rotatory.

- Who would now dream of retaining the form of the Flail in the Threshing-machine, or that of the Oar in a Steam-ship, or of putting the Piston-rod to work at the end of a Pump-handle? Yet doubtless these piebald attempts were all made in their 
day, till the several inventors had come to see in turn that

"'Tis gude to be off with the old love

Before ye be on wi' the new!"

'But no one can imagine, without trying it, the difficulty of making the mechanical part of the question intelligible to the agriculturist, and the agricultural part to the machinist. The steam-engine has no taste whatever for straight draught. $\mathrm{He}$ is a revolutionist, in the most exact sense of the word. He works by revolution: and by revolution only will he cut up the soil into a seed-bed, of the pattern required, be it coarse or fine. And that, it is my firm belief, he will be seen doing at a handsome average, before a very large portion of another century shall have passed over. Why should it not be? Why should not a strip or layer of earth be cut up into fine soil at one operation (and sown and harrowed in, too), as easily as a circular saw cuts a plank into saw-dust? But when you come to employing
a Steam-engine
to turn a Drum,
to wind a Rope,
to drag a Plough,
to turn up a Furrow,- 
and all this as a mere prelude for an after-amusement to all the ancient tribe of harrows, scufflers, rollers, and clod-crushers, to do supplementally the real work of cultivation,--it reminds one of "the house that JACK built." One can hardly blame the iron ribs of any respectable boiler for bursting at the first trial, in a task so utterly at variance with every known law of mechanical progress, so repugnant to the economics, I had almost said the very ethics, of the steam-engine.

'I trust to be some day forgiven for so boldly speaking; but I am sorry to think of one useful shilling being thrown away in the attempt, unprofitable even if successful, of harnessing steam with horse harness, to do horse's work in a horse's way; the implement itself, whose wretched work (on clay soil) it is set to accomplish, being a tool with sentence of death written upon it, be it as ancient as it may, for its tyranny to the subsoil, which bears the whole burthen and injury of its laborious path.

' I say the Plough is essentially imperfect. What it does is little towards the work of cultivation; but that little is tainted by a radical imperfectiondamage to the subsoil, which is pressed and hardened by the share, in an exact ratio with the weight of 
soil lifted, plus that of the force required to effect the cleavage. Were there no other reason for saying it than this, this alone would entitle the philosophic machinist to say, and see, that the plough was never meant to be immortal. The mere invention of the subsoiler is a standing commentary on the mischief done by the plough.

' Why then should we struggle for its survival under the new dynasty of Steam? The true object is not to perpetuate, but as soon as possible to get rid of it. Why poke an instrument seven or eight inches under the clod, to tear it up in the mass by main force, for other instruments to act upon, toiling and treading it down again, in ponderous attempts at cultivation wholesale,-when by simple abrasion of the surface by a revolving toothed instrument, with a span as broad as the hay-tedding machine or CrossKill's clod-crusher, you can perform the complete work of comminution in the most light, compendious, and perfect detail?

' Imagine such an instrument (not rolling on the ground, but) performing independent revolutions behind its locomotive, cutting its way down by surface abrasion, into a semicircular trench about a foot and a half wide, throwing back the pulverised soil (as it 
flies back from the feet of a dog scratching at a rabbit-hole): then imagine the locomotive moving forward on the hard ground with a slow and equable mechanical motion, the revolver behind, with its cutting-points (case-hardened) playing upon the edge or land-side of the trench as it advances, and capable of any adjustment to coarse or fine cutting; moving always forward, and leaving behind, granulated and inverted by its revolving action, a seed-bed seven or eight. inches deep, never to be gone over again by any after-implement except the drill, which had much better follow at once, attached behind with a light brush-harrow to cover the seed.

- It is hard, by mere language and without a diagram, to describe intelligibly to the mind's eye an instrument that has not been seen; familiar as it has become to my own. My notion may be wrong, but I am strongly induced to feel that such an instrument alone will ever fulfil the requisitions of the steam-engine, which shortens and remodels every labour it undertakes, and never condescends to old appliances, except where they are themselves intrinsically perfect in their mode of action.

' Why did Steam reject the Pump-handle and the Oar? Because, in both, the leverage is obtained by 
loss of labour and time, occurring during the backmovement necessary to the manual, but not to the mechanical agent. For the same reason, whenever it is applied to till the earth, it will antiquate every instrument that cultivates by traction, because traction is not only not necessary to cultivation, but is inherently mischievous on other grounds, apart from the clumsiness, inaccuracy, and incompletness of the work it turns out.

'But the Stones! There is much fear expressed for the teeth of the circular-cutting implement $I$ have described, when they come in contact with stones. The objection would have been equally valid, at first sight, against the use of the Plough or the Scuffler. Let me see the instrument in use where there are no stones (and there are plenty of broad acres in England of this class), and it will not be long before it gets upon the others. If it cost five pounds an acre to clear them out, it must be done, and would, in such case, pay well to do it. But the truth is, that the instrument itself suggests the kind of machine which, with a little adaptation (greater power and slower motion), might perform this preliminary service at the least expense. If land is to be like a garden in one respect, I see no good reason why it should not 
in all. I do not think stones will stand long in the way of Steam, or be readily preferred to bread, if, where there happens to be none, the steam-driven cultivator can be brought to bear, which, after the simple and beautiful example of the mole, shall play out the long comedy of our present field cultivation in a single act, present a finely-granulated seed-bed by a single process, almost at the hour required, and trammel up the "long summer fallow" into the labour of a day, with an accuracy as perfect as the turning of a Lathe, and an aëration (and consequent oxygenation) of the soil as diffusive and minute as that of a scattered mole-heap, or the dust flying from a circular-saw bench.

'Implement-makers and mechanicians would not be long in understanding all this, if they were not under the supposition, received at second-hand by them, and therefore the more difficult to eradicate, that ploughing is a necessary form of cultivation to be kept in view. Once let the Q.E.F. be clearly understood by them-once let them be made fully to perceive that "ploughing" is merely the first of a long series of means towards the accomplishment of a particular end, that end being the production of a seed-bed, of suitable depth and texture, and with the soil as 
nearly as possible inverted in its bed-and I do not think they will be long in setting the steam-engine about its proper task, in the proper way. But their attention is distracted, at present, from the end to the means. They are taught to think that the plough is a sine quâ non-that steam cultivation of necessity implies steam-ploughing, and they are led to give up the task in despair, because they are at fault upon a false scent.

- We have many rolling implements employed in the field, but we have only one instance of a revolving implement. The clod-crusher and the Norwegianharrow roll; the hay-tedding machine (one of the best instruments ever invented) revolves. I use the words somewhat arbitrarily, but the difference I allude to is very important. The first are liable to the evil of "clogging;" because they derive their axis-motion from the soil as they pass over and press upon it. This action must not be confounded with that of a machine which has its cause of revolution within itself, independent, and acting upon the soil as a circular saw acts upon a board, or the paddlewheel of a steamer upon the water. The teeth of a saw clear themselves, by the centrifugal motion they communicate to the particles they have detached from 
the substance they act upon. A circular "cultivator" steam-driven will do the same. It does so more effectually according to the velocity of revolution and the state of the soil. This last incident is as it should be; for it is not desirable that a clay soil should be dealt with when not in a proper state for tillage; and one great advantage of such an instrument as I point to would be that it would so immensely enlarge the choice of period, by its compendious accomplishment of the whole work of culture.

' My object, however, is not so much to advocate the particular mode of applying Steam-power which I myself suggest, as to explain the grounds on which I feel more and more strongly assured that the attempt to employ it through the medium of the plough must be eventually renounced.'

'There's one thing,' said Mr. Greening, who had been listening throughout with unusual attention and perseverance, and nodding knowingly at the end of each sentence, as if the idea was steadily gaining ground upon his mind,- There's one thing that you haven't mentioned, and on your own side of the matter, too. The finer the soil's worked down, the greater the effect of the manure: of that 
I'm certain sure; large as I like to see the clods on a fallow.'

'I was afraid you would have taken the other side of the question on that point,' said I, ' on which a good objection may be taken,-and answered, too; and which we must not omit: but it was not because I had said my say out, that I came to a pause; but rather because $I$ felt that there was still so much unsaid, and I am too tired to say it now, and you to listen to it, I should think. Come, it's no use denying it. We must adjourn. Besides, I want to hear your objections. I know they'll rise thick and threefold, when you've left me. When shall I hear them; to-morrow?'

' To-morrow let it be, with all my heart! I doubt you've given me a bad nightcap, though! When I get a subject of this sort into my head, it sings in my ears half the night: and when at last I do go to sleep, I dream of it till I 'wake again. Well! "In for a penny," as they say: so I shall be glad to hear it out. Maybe you'll finish it to-morrow. I don't think I shall ever look at a plough again without thinking of you !'

And Mr. Greening took his departure; not more busily impregnated with a new subject than he left 
me with an old one: for of all the stimulants to deeper thought in your own mind, what so powerful as the sustained effort to develope your earlier conceptions by the slow and detailed process of conversation, and that with a not too easy or unobjective listener? Idle and valueless as yet, as the unsmelted Ore, is the Thought that has not been struck out into the current coin of simple words. And this once accomplished, who shall say where that currency may lead, or in whose hands it may yet thrive, hereafter?

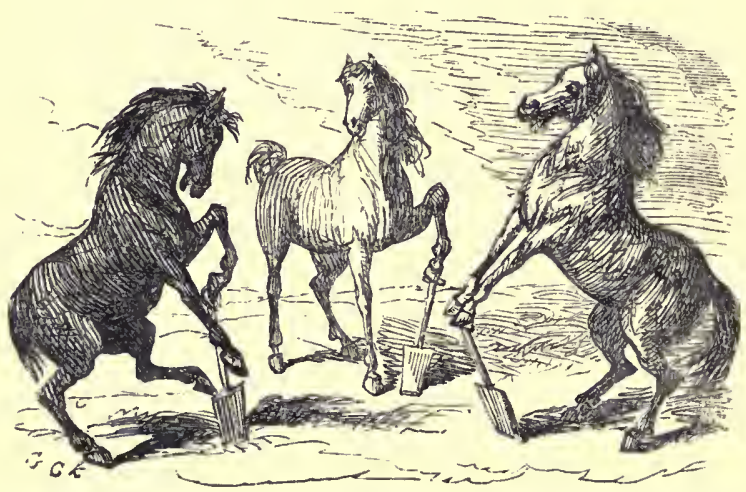

'Steam-power, -no more to do with the Plough than a Horse has to do with a Spade.' 


\section{XXI.}

\section{THE ' STEAM-CULTIVATOR.'}

WHAT an irresistible tendency there is amongst men to draw each other in caricature! How prone we are to magnify those features in which the character of another differs from our own! I doubt not that if Mr. Greening had described our late interviews (' if the lion had been the sculptor'), our readers would have been at least as much amused, the other way. I should like much to see the 'per contrà' that he would have drawn out.

I am justly led to this conclusion because my notes of our further conversations show how completely I had underrated both his interest, and his penetration, in the subject I had so suddenly broached before him; taking it too readily for granted, that a thoroughly practical man, like himself, could not stretch his imagination to the point required to make him enter into my views, or the suggestions I had made.

This was far from being the case. He had heard, 
I suspect, and interpreted too, after his own fashion, every word I had said and read to him. For, after our late-described interviews, his 'trespasses,' as he called them, on my Farm became more and more frequent. Whether it was that he thought the demerits and deficiencies of the plough were more strikingly to be seen and freely studied upon my soil than on his own, or whether he reckoned upon the chance of hearing them more boldly outspoken, I will not attempt to decide : but for some reason or other I soon found him a frequent, and by degrees a more (so to speak) long-winded listener. Not a week had elapsed after our last conversation, when a rainy day drove him into my den for shelter, and as ready a prey as any beast that ever roamed the wilds of agricultural theory could desire.

' I'm afeard,' he began, after ensconcing himself in the very same chair, with one of the very same cigars, opposite the same fireplace, and in precisely the same attitude-'I'm afeard it won't leave off for some time. I should like to hear you out, Sir, about that Steam-ploughing-I beg pardon-Steam not-ploughing-“cultivation"-anything you like to call it, that you was on about the other day. I don't know how it is, but it seems to haunt me like. You've done 
me harm [" $\mathrm{Hal} "$ ?] you have indeed! I used to love follering the plough, and see it heave up the furrowslice so smooth and nice, and swelling the rich earth as it swam along, better than anything else I know on earth-except, perhaps, hearing my little Fanny reading when $I$ come home sleepy at nights,-but now-I don't know how it is, I seem to run my head agin' it every time $I$ see it, on stiff land, a-squeeging and pressing and kneading its way along: it gives me the very headache to look at it; it does really! Now, please not to mind about the long words, for once; but let me hear it on to the end. I should like to know the worst on it-and the best if there is any. I want to know now, really, why, if Steam's the proper thing-why it hasn't been done. They do most things by steam now-a-days : if it is to get upon the fields, why don't it? What stops it?'

' You have asked me,' said I, ' the very question I ask - too- Why is it that amongst all the greatinventions of the day, the subject of CuLtivation BY STEAy seems to hang fire? Not for want of thought upon the topic; for there are many minds full of thought about it, and few people now-a-days believe the thing impracticable : indeed, no one can find any good reason why it should be so. There is no parti- 
cular difficulty or peculiarity about the mechanism of cultivation, to "forbid the banns" between the soil and the steam-engine: it is generally felt that the match will take place some day, slow and unpromising as the courtship may seem at present. I join hands in this belief; and in the meantime ask your special attention to these preliminary points, which may help to account for past delay, and possibly to advance the question from its present silent condition. Silent, because invention is apt to be so. Self-interest keeps it so ; and in the meantime a generation may pass by, and nothing be practically done towards a consummation which, once accomplished, it requires no ghost to see that Great Britain would leap ahead in agriculture as much as her mines of coal and iron, and her still deeper and richer mine of mechanical skill and improvement, have led her to do in every art and manufacture upon which the breath of steam has been brought to bear.'

Here in fact lies the grand motive in the matter; and one so emphatically important in reference to this particular application of steam-power-yet to be achieved - that one cannot help wishing that all who really think at all about it - who are not of that class of infidels who think the womb of invention is age- 
stricken, and that nothing is possible but what has been done-would come into committee upon the subject, and abating a little of that exclusive faith which each has in his own cleverness and chance, would help to bring in this tide, as the tide of human progress is wont to come in-not by one great wave, all at once, but a great many waves after and upon each other.

There is one grain of comfort, and of corresponding hope, visible already. A good many thinkers have got quit of the steam-plough, and got as far as the spade: that is something. It is something, I repeat, to have got to the spade; for those who have got thus far will not stay long there. The public mind moves slowly; but once in motion, the inertia once shaken off, and the vis inertice once set a-going, it will never stop till it reaches the goal.

Again and again be it repeated, that it is not ploughing, neither is it digging, that we want. These are only means. What we want is the end: we care not for the process. Give me A SEED-BED: show me the soil comminuted, aërated, and inverted, six or eight inches deep, and I will not ask you how it came so. What does that matter? If you wanted your coffee ground for breakfast, to a certain fineness of texture, would you be very particular to ask whether the mill 
that crushed the fragment berry had worked by horizontal, vertical, alternate, elbow-crank, or by circular motion? If the farmer or the gardener could only have his seed-bed made ready for him as fine as a new mole-heap, or to any other coarser texture, according as he wants it, do you think he would care whether the soil had been first cut into longitudinal strips, plough-fashion, or into square cubes, spade-fashion, before it was finally granulated for use? Surely the one is as indifferent as the other; and singularly enough, both offer problems far more difficult to the steam-engine (if anything can be called so), than the performance at once of the ultimate and entire process without these preliminary forms at all.

Until steam-power was discovered, this possibility did not exist. Wind and water power being out of the question, there remained nothing for it-no other power that could be taken to the field-but men or horses. Ploughing or digging, then, were the indispensable preliminaries : there was no getting on without them : they were but preliminaries, it is true, the former leaving everything, the latter a great deal (according as the work was done) to be accomplished afterwards to complete the cultivation.

But it is not so now. Since the birth of the steam- 
engine-no such very long time ago-the whole elements of the question are altered. There exists now a portable power-not limited to horizontal action like the horse, nor to vertical action like a man with spade or hoe,-a power which, if merely told what to do, will go and do it, merely dropping a hint into your ear that circular motion is its favourite.

But the willing giant stands idly panting and smoking: for nobody can agree to tell him what to do. One says, 'Gro and plough!' another says, 'Go and dig,' each mistaking the means for the end, and trying to yoke this youngest born of human genius to the peddling routine of manual or equine capacity; out of the very perversity of backsightedness that clings to forms and modes which belonged to the implements, not to the task,-backsightedness that would with equal reason puzzle its brains in looking for the pole and splinter-bar of a locomotive, the pendulum of a watch, or the paddle-boxes of a screw-steamer.

But if it is not ploughing, and it is not digging, what is it? 'Go to the Mole, thou dullard' (the old proverb might be travestied), ' consider her ways and be wise,'- who without any coulter, share, or mouldboard-without spade, hoe, or pickaxe-leaves behind her in her rapid track a finer mould than ever 
Raxsome, Howard, or Crosskili- - than ever spade or rake produced, or the most careful-handed gardener chopped up, to pot his plants with. The very rabbit that scratches his hole in the ground, or the fox that scratches after him,-like a king-crab, to eat the kernel and lie in the shell,-or the dog that scratches after both, the whole tribe of 'claw-foot' in fact,-had scratched hard earth into soft mould before ever the plough or the spade, or even the more ancient Hoe, had broken ground on this planet.

Let us begin from the beginning: let us take 'Cultivation' itself into thought for a serious moment, and analyze it into its simplest elements, dropping all conventionalities of plodding custom. What is it? How would you do it, if you had neither plough nor spade nor hoe nor rake to help you? Surely with the same tool that the Monks of La Trappe use to dig their graves, and in the same manner! If the mole, the rabbit, the fox, the $\operatorname{dog}$, are not sufficient indicators, take the hand of man, glove it with hardened steel, multiply it a dozen or twenty times, till you have an instrument as broad as Crosskill's clod-crusher, each hand or claw with its separate arm forming the radius from a central shaft, which bristles all around with a forest 
of such arms, a sort of revolving BRIAREUs, not rolling - let that be especially remembered-but steamdriven, a thousand $d o g$-power if you please, for we must not even mention horses, or we shall drop back into the old Scylla and Charybdis of 'traction' and of 'rolling,'-two ideas each to be eschewed like poison.

Let us suppose the picture of this formidablelooking cylinder of claws to be sufficiently described, for the moment-reminding one, at a distant view, of a half-breed between a hay-tedding machine and a Crosskill's clod-crusher (but unlike them,-fundamentally distinct from any and every instrument that was ever seen afield, as doing its work not by traction, not by its rolling weight, but DRIVEN by its axis, as the steam-paddle, the circular saw, the driving-wheel of the locomotive, are driven), supported by its own apparatus, and abrading the soil with"its armed teeth, first cutting its trench, burying itself to the required depth, and then commencing its onward task, tearing down the bank (so to speak) on the advancing side, canting back the abraded soil, earth's saw-dust, ' comminuted, aërated, inverted,' into the trench it leaves behind.

If I have failed in making the picture clear or 
intelligible, it is yet not that about which $I$ care so much, as to 'draw aside the curtain.' The idea of ploughing and digging stands like a thick blind before the whole philosophy of the subject, and screens the inventive mechanician from the simple application of his mind to the quod est faciendum. His faculties are clogged, stupefied, held in check by the pestering contemplation of processes that enter not necessarily into the problem to be solved, nor need appear in its solution. They are unessential to the matter. They became so the very instant the steam-engine was discovered; a power, and the only one we possess, that can be carried to the field, and put into an agricultural machine-like the mainspring into a watch - to give it independent intrinsic action within itself, owing nothing to, but entirely separate from, the traction and progression of the implement along the field. Hitherto there is not even the attempt so to apply it; it has never had a chance. Every field-implement we have, works by traction-like the Pedometer that ticks because the wearer marches; but with steam for our mainspring, we can make the watch tick independent of the wearer. When we understand that, when we have in idea and in fact detached the work of cultivation from the 
mere progression of the implement, made them perfectly separate and independent, so that if you ceased to proceed, your ' coffee-mill' would still be at work, and only wanting fresh coffee to grind; then, and only then, shall we have laid hold of the end of the clue that leads to Cultivation by Steam; for then, and only then, shall we have begun to appreciate the real and unique value of the new agent we possess. To suppose that it would gear its noble faculty to the dragging of ploughs, or the redoubled solecism of a rolling spade-machine, is to overlook the axioms of natural law, the fundamental relations and exactions that govern the progress and throw light upon the history of Invention.

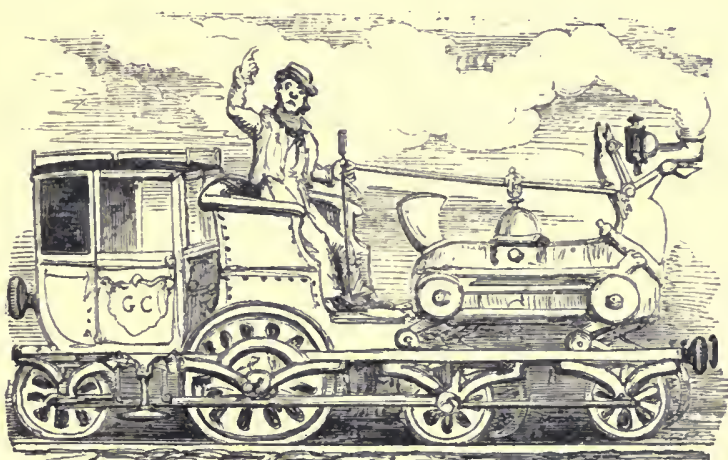

'The willing giant stands idly pantung and smoking.' 


\section{XXII.}

\section{THE SUBJECT CONTINUED.}

I CAN call to mind no practice, in the intercourse with others, more improving, sometimes more humiliating, than the attempt to explain in clear words to a listener not disposed to give much quarter, an idea with which one's own mind has been long familiar. A large portion of what we call our ' mind' consists of the Imagination, a proverbial deceiver, painting images (as its name implies) upon the retina of thought, apparently all real, but fading into dimness, crumbling often into the utmost confusion and intricacy under the attempt at delineation by the tongue. This is of every-day experience. But there is another traitor not so commonly arraigned and brought to trial,-the Memory. What has long been on our minds, we are apt to regard as we do those faces that we have met again and again, and only become con- 
scious of our ignorance when we have occasion to address the owners by name. 'Talking makes a ready man, reading a full man, writing an exact man,' says the old proverb. That laying out of a subject in detail which talking requires, clothing it in simple and intelligible language, yet illustrated with analogies and metaphor, suited to the individual addressed, is an exercise in itself susceptible of such improvement, that one is sometimes tempted to ask, whether, after all, language owes more to Thought, or thought to Language.

And thus, in the conversations that ensued with Mr. Greening, derived from my original promise to him to put this question of Steam-cultivation into 'plain English,' I soon felt that it is one thing to see a matter as plain as a pike-staff before your own mind prepared to understand it, and a very different thing to make it intelligible to those who have never given any express attention to it before. In deference to its importance I will try to restate the whole question; dropping, for continuity's sake, the dialogue form in which the subject was, by frequent and useful objections on his part, made to develope itself. 
Before the discovery of Steam-power, and its application to machinery, there was no such thing as a motive power that could be carried about, and applied where and when and how you pleased, except animal power. The plough, the spade, or the hoe (with their varieties), were the only possible modes of effecting the task of cultivation. The comparatively recent discovery of steam-power altered the condition of human life in this particular. The modes of action to which cultivation was before limited, and which are exemplified in the use of the three instruments just named, became, on the discovery of steam, no longer the necessary and only modes of performing the act of tillage. From the nature of things it was morally certain that whenever that new Power was applied to this act, it would be through an instrumentality as different from the plough, as the plough was from the spade. If a man will only give himself the trouble to think how total a revolution the application of steam effected in the navigation of a ship, and the locomotion of a carriage, he cannot very well fail to see what is meant by the saying that a new power requires a new process. It is a solecism in art, as well as science, to attempt to yoke 
steam to a plough. There is no affinity between them; any more than, as I said before, between a horse and a spade.

I have found it inexpressibly difficult to get this leading postulate clearly and once for all understood. Till it is so it is hopeless to attempt to proceed. The idea of an instrument to be dragged through the soil, as a plough is, from one end of a field to another, poisons, more or less, nearly every effort towards steam-cultivation I have seen. How difficult it is to unlearn!

When the attempt was first made to run steamcarriages on common roads, it was soon found that however good a macadamized surface might be for a wheel to roll upon, under a carriage drawn by horses, it broke away into a perfect gravel-bed when the new power, instead of pulling the carriage (the wheels simply rolling underneath), laid hold of the Wheel itself, and produced the locomotion of the vehicle by forcibly driving that round. The very best road gave way under the severe friction of this new mode of producing locomotion, and so did the tires: and nothing could be done till both road and wheel were made of solid iron. The new power requires a new 
process. Instead of pulling the carriage it drove the wheel, and in driving the wheel it tore up the stones of a granite road.

Let us put on our Agricultural spectacles, and apply this parable. When Steam-power is brought into the field (audiat qui aures habet!), it will ' play out this play' over again. Its faculty and virtue consist not in pulling vehicles or implements, but in driving wheels: and when steam-driven wheels will tear up granite road into shingle and gravel, and move the Carriage too (for so it did, only not fast enough for modern travellers), what forbids the hint being taken by the 'audax Japeti genus,' that have happily applied so many accidental hints before, and the same refractory giant being set to rasp up cleverly and methodically with sharpened Mole-like claws the tender soil, when he has shown his ability to tear so tough a one with the mere palm of his hand? And what forbids, either, that he should spare off a little of his redundant steam in moving his own carcass along, meanwhile, at a pace under half a mile an hour? 'What you lose in speed you gain in power;' and an instrument which completes the whole work of tillage, as it moves along, will 
hardly be required to go much faster. At that speed it would cover four acres a day — not of 'ploughing,' not of ' harrowing,' not of 'rolling,' not of 'scuffling,' not of ' rolling again,' ' cross-ploughing,' 'clodcrushing,' ' rolling again,' ' ridging up,' 'sowing,' and 'harrowing in ;' but of all these epithet processes in one comprehensive act-and word-Cultivation.

Is it not astonishing, with such experiences as we have before us in England, that since the first introduction of Steam-power to the notice and assistance of mankind, nobody has ever yet attempted to apply it in its own way to the definite and simple work of cultivation? It is put to cut chaff, to make saw-dust, to granulate powder, to make pins' heads, to reduce all sorts of coarse material into fine-and all by wheels, - circular motion, and nothing else, for nothing else will it accept,---but nobody can persuade his mind to believe that by the self-same action, and no other, it can cut up a seam of soil eight inches deep and five feet wide, and leave it behind granulated to as coarse or fine a texture as the nature of the seed or season may require, and inverted in its bed. It is not ploughing, it is not 
digging, it is not harrowing, raking, hoeing, rolling, scarifying, clod-crushing, scuffling, grubbing, ridging, casting, gathering, that we want: all these are the time-honoured, time-bothered means to a certain REsult. That result is-a seed-bed : and a seedbed is, simply described, a layer of soil from six to twelve inches in depth, rendered fine by comminution, and as far as possible inverted during the process.

You may call this ' Theory,' my good Mr. Practical, but I tell you it is Truth : simple, philosophical, practical Truth. Since the Invention of the Steam-engine, it might and may be done at one process, as easily as before in twenty : and it will be. Before we depart this life, we shall see one more wonder moving upon the face of the earth, something of this form and fashion-to wit-a complete locomotive engine on four wheels, the fore pair turning on a transome, the hind ones fixed; behind them a transverse cylindrical shaft, about three feet in diameter, and from five to six feet long, reminding one of a cross between a clod-crusher and a hay-tedding machine, armed with steel tine-points, in shape like a mole's claw, arranged so that the side-lap of each claw may cover the 
work of the other, and no interval or ridge be left uncut: the extremities of the cylinder just covering the wheel-tracks. This cylinder of claws you will see raised or depressed at pleasure by the engine-driver, and adjusted to slow or rapid revolutions, worked either by cog-wheels, or geared from the drum of the Engine. That is the 'cultivator.' A platform from the Engine extends over it, ending in a sort of movable tail-board, which may be raised or depressed at pleasure, to regulate the settlement of the soil which scatters from it. The revolution of the cylinder is not against but with that of the wheels, not dragging or retarding, but rather favouring the advance of the whole machine," which is moved slowly forward by detached power from the Engine.

When, at some future day, and by some pen not yet out of straight strokes and pothooks, there shall be written, for the edification of the next agricultural public, an historical sketch of the 'Rise and Progress of Steam Cultivation,' it is to be feared that some of the reflections will not be of the most complimentary kind to the genius or the faith of the generation that has embraced nearly in one expe- 
rience the development of Steam Navigation, of the Railroad system, the Electric Telegraph, and other kindred appliances in the many-pathed field of practical science.

'It was strange,' we may suppose our future annalist to write, "that amidst the blaze of surrounding discovery in the arts that economize the labour and advance the condition of man, an application of steam-power that must surely have pressed with such powerful motive and exigency on a period when circumstances seemed especially to evoke the mechanical resources of the kingdom, by way of setoff to its often-urged disadvantages in climate and in fiscal burdens, should have been long regarded rather with the apathy evinced towards the cobweb speculations of dreaming enthusiasm, than dealt with as a practical question by practical minds. While zealous agriculturists were eloquently excited once a year over the weight of an ox, or the twist of an improved mould-board, "Science" was satisfied, and "Practice" seemed to tread on the heels of perfection! Under such patronage, "Improvements" in the established implements of tillage were of course as numerous as the moiety of twenty acres of ground 
could conveniently accommodate for annual Exhibition. A revolution impending over Tillage itself was of course the last thing dreamt of. It is ever so. True, a few black funnels might be seen smoking in the show-yard, and the whirling drum of the steamdriven Threshing-machine had, thanks to the previous invention of a certain Scotch lawyer, made the agrestial mind forget to expect, or its prizes to stimulate, improvements in the Flail. But the principal and time-honoured act of agriculture proper, of cultivation itself, still laboured under its ancient tribe of horse-adapted implements. The Plough and the Harrow were still in the ascendant: the instruments of equine-tillage were still received as its essential agents; and people who would have smiled at the mechanical curiosity of a steam-Flail, gravely anticipated the day when some such combination would be triumphantly achieved for the darling tool whose Heaven-invoked "speed" had long supplied the toast and figure-head of "Prosperity to Agriculture."

' Yet it can hardly be wondered at,' our aggravating Critic will continue, 'that men should have slowly and with such difficulty eradicated from their 
minds a mode of tillage so long compelled by the very nature and necessity of animal power: every child that has wept and smiled over the "Death of Cock-robin" knows when he hears-

$$
\begin{aligned}
& \text { Who'll toll the bell? } \\
& \text { "I," says the Bull, } \\
& \text { "Because I can pull," }
\end{aligned}
$$

that Mr. Bull was guilty of a pun; that the 'pull' of a quadruped is only horizontal; that his strength can be applied in no other way; and that when you employ a four-footed beast to cultivate the soil, you have no choice left but horizontal traction, from one end of the field to the other; a mode of action which commenced when the spade was abandoned in fieldculture for the plough, and which was to continue so long as horse-power tillage continued; and no longer: since it formed (as the spade had already shown) no necessary element of cultivation, and had no relevance whatever with the action or capabilities of the Steam-engine.

' Steam-power having, however, been hitherto chiefly cmployed in Manufactures, and its versatile modes of application being unfamiliar to the agriculturist, we can scarcely be surprised, that even those 
few who gave a serious thought to the subject, looked upon the Steam-engine rather as a piece of concentrated horse-power to be harnessed as best it might to the existing horse-rrorked implements, than as a New Agent, whose entry on the scene of action enabled him to reconsider the whole philosophy of Tillage; to analyze it into its elements, to see what it is; what it had been when confined to manual power under the primeval dynasty of the Spade and Hoe; what it was under the advanced but equally special limitations of animal power, as exhibited in the Plough and every other implement of draught; and what it might be under the wider sphere of available process which the Steam-engine presented. What was cultivation? Did Steam-power offer any cheaper, better, or more direct mode of performing it, than manual or animal power had done? Could it accomplish in one act the problem of converting the hard clod into fine soil? Could it, like the little Mole, cut a seed-bed out of the solid? If so, why entangle it with implements foreign to its nature, unessential to its action, and behind it in that order of inventive progress whose deep-cut label is "Vestigia NULLA RETRORSUM"? 
'But the Plough had left its ridge-and-furrow impress not more in the fields than, alas! on the mind of the agriculturist of that day. It was long, and naturally so, before he could bring an imagination preoccupied with the old-established system of field-culture, to recognise its impending emancipation from the whole chain of subordinate necessities exacted by the employment of horse-labour. The old fable had become reversed: the quadruped was riding the man : and to shake him off was now the difficulty! For a century after its invention, the Steam-engine lay still-born to the soil, and the virtue unappreciated of a new power which could antiquate mere implements altogether, and convert the cultivating agent into a machine, in the strict sense of the word; a machine whose locomotion across the field was a mere collateral incident, not a means; as the sheep, or ox, walks over the pasture to crop it, but does not crop it by walking.

- And yet it was somewhat strange, too, that recognition should have been so tardy, and prejudice so ineradicable on this point, when we reflect that modes of tillage already existed, so totally and specifically different in action from all horse-worked implements, as those both of the Spade and its more ancient con- 
gener the Hoe ; ${ }^{*}$ and that the perpendicular and very effective action of these manual tools, contrasted with the farm implements of draught, might have dimly suggested the possible discovery of other means of cultivation as different from all of these as they were from each other. Anyone who had ever seen a nutmeg rasped away into fine atoms against the armed surface of a grater, or saw-dust scattered in heaps from timber by the teeth of a circular saw, and could find room in his imaginative faculty for the contemplation of this mechanical process, side by side with the agricultural fact that a seed-bed is only a layer of comminuted soil a few inches in depth, might surely (one should now suppose) have saved the credit of his generation by some more congenial suggestion for the effectuation of tillage by Steampower, than attempting to bind it down to an apprenticeship in which Ploughs and Harrows, Rollers

* In some of the southern countries of Europe, as in Spain and Portugal, and in the offshoots of the latter-Madeira and Brazil-the Hoe is the almost exclusire implement of (manual) tillage. The spade is, originally, a form of the Hoe, adapted to more northerly climates, where the moistness of the soil increases the labour of cultivation by forbidding the tread of the workman on the worked land, and obliges him to stand on the "landside' of the trench. 
and Scufflers, or even the spade, were still to figure as the rude terms of the Indenture, as out of keeping with its genius and aptitude, as they were nonessential to tillage itself analytically regarded, apart from its conventional modes necessitated by horse or hand-power.'

Such will be the kind of after-reflection thrown back upon his forefathers of this generation by our future agricultural historian. ' 'It is true,' he will be obliged to add, 'there were not wanting heaps of patents and pretensions crowding in confused succession on the public notice, 'during this period of inventive decrepitude. Wherever there is a lack of grain, there are plenty of weeds to fill the gaping space. There were plough-dragging engines, stationary and locomotive-there were "ploughshares on circular frames," "revolving spades," and all the train of piebald monstrosities and biform incongruities that mark those periods of false gestation and miscarriage in the annals of invention, when wouldbe discoverers, dashing blindfold at unconsidered combinations, are each profoundly busy putting " new wine into old bottles;" never devoting one serious hour of study to the simple elements of the problem they undertake,-the mechanical act to 
be accomplished, and the mechanical means necessary to accomplish it; but (like the scribe who ventured a treatise on Chinese Metaphysics, by searching for "China" and "Metaphysics" in the Cyclopædia!)-taking a plough and a steam-engine -or a spade and a steam-engine-as the inevitable sire and dam of the fore-determined "cross," plunged headlong into the labyrinth of complex and solitary contrivance how to join things which Nature had put asunder.'

\footnotetext{
' velut ægri Somniı, vanæ

Fingentur species; ut nec pes, nec caput uni

Reddatur formæ.

Infelix operis Summâ, quia ponere totum Nesciat!
}

Such, we may anticipate, will be the storm of keen reflection showered over our graves by some writer of the end of this, or beginning of next century, who looks back upon the origin of steamagriculture from just such a point as we do now on that of steam-navigation; who will be as familiar with the sight of soil pulverized a foot deep, in one act, by surface abrasion from a steam-driven cylinder [armed with the Talpaian claw that 'works i' the earth so fast,' and solves in the dark, beneath our 
very feet, a harder problem !] as we are with ships of a couple of thousand tons, driven through the water like a duck with her web-feet at work beside or behind her, in either case obedient to the steam-law of circular motion.

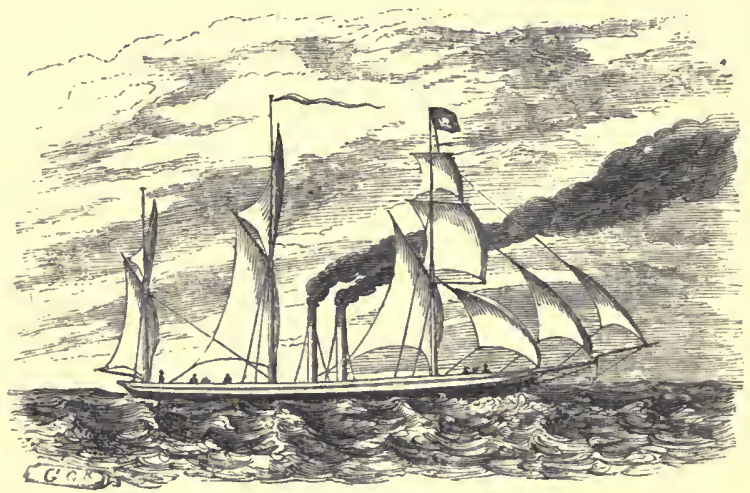

"Vestıgia mulla retrorsum." 


\section{XXIII.}

\section{MACHINERY ON THE CLAYS.}

'Matrer is infinitely divisible,' says the philosopher. 'Cultivation consists in pulveration,' says Tull. 'The greater the comminution of the soil, that is, the exposure of its internal superficies, the greater its power to absorb Ammonia, the essence of manure, from that great storehouse of fertility- the atmosphere,' says the chemist. ' Soils,' says the geologist, ' consist of three elements, Clay, Sand, and Lime; the more suitably they are inter-combined, the more fertile the resulting combination.'

All this looks simple enough. Yet in the judicious application of these few truths lie the great practical problems of Husbandry! All truth is simple: ' Simplicity is the test of Truth.' Yet, like the three primary colours, 'Red,' 'Yellow,' and 'Blue,'-bright, clear, and simple as they are to the eye, how infinite their varieties of combination; what scope for judgment, or for error, in their admixture, or that of 
their Secondaries; what ample room for blunder, what diversity of apparent 'accident' and mischance, what damage of unlooked-for incident and unallowedfor circumstance! What open, pathless wastes for the blunderer and the empiric, what narrow and difficult steeps for the student who has the heart to climb !

O Agriculture! thou Science of sciences without a School, thou Philosophy without a 'Porch' (even for shelter!), thou University of unexamined graduates, all 'Masters' and no 'Students' — when will thy ' degrees' be better recognised, thy principles be moretruly studied, thy ' privileges' be better appreciated, for being the better understood? When will men consent-condescend - to LEARN - an Art that claims a share of light, and illustration, and practical advancement, from every physical science that has sprung into being, since Bacon traced out knowledge to its source, and Chemistry, THE PHILOSOPHY OF MATTER, gave the best of posthumous illustration to that great inductive theory that rests all knowledge on the one sole basis of Experiment?

When that day comes-when the living chemistry of the Soil is accepted and understood, not as an amusing and probable speculation, the vaguely suggestive 
subject of a ' Lecture' before a patronizing Council ; but as a solid, working-day, every-day, practical fact, - then the Mechanics of agriculture will not be far behind! Then the 'touching truisms' of Tull-tlıe Galileo of agricultural science, the Luther of modern husbandry, struggling single-handed against a whole Dark-age of ignorance and banded prejudice-will reach the 'promised land' he saw and pointed out with the finger of the seer, but was never allowed to enter. Blending into the truest of union with the afterdiscoveries of Davy, De Candolle, Liebig, Boussingault, and our own not less deserving Johnston and Lawes, and others of distinguished note, his theory of ' Cultivation' will propound matter of deep thought and combined action equally to the chemist and mechanician.

When the simple mechanical idea of pulveration, comminution, subdivision, or by whatever other long name men may please to understand it, shall be seen in its chemical meaning, as connected with the food of plants-the 'pasture of roots', as Jethro Tull, with appropriate metaphor, described it,- - then the clain and application of the Steam-engine will be made out and recognized, and the name of James Watt will be found as important to agriculture as that of Humphry Davy. 
It is a mere question of Time. We travel slowly; and, like lazy wheelers, throw back our ears and bite the pulling horse: but if ever the shadow of a coming event was visible beforehand, even to the unimaginative eye, this of the true mechanism of Cultivation is one that is beginning to be visible. Call the Seer 'visionary,' if you please. Visionary! of course he is visionary! it is his place and office, his duty and profession to be so, and to bear the consequence! He sees in 'vision :' it is by far-sighted vision that he catches sight of the 'man's hand' in the horizon, which others cannot see, and will not believe till it touches their eyeballs. And then they will swear they always saw it, and will have forgotten that they ever didn't see it. The man was never yet found that would head a deputation to carry the world's recantation and apology to the derided prophet whose derided prophecy has come true. With the advent of the Fact, dies out the prophet's only distinction,-- to be ridiculed. Such was ever his fate; and will be, to the end of time; varied only by the politer form and phase that civilization gives to persecution.

Yet, in the present active progress of invention, the transition is so rapid between one phase of our industrial condition and another, that the difficulty of 
inducing men to realize the possibility of a coming discovery seems almost to tread upon the heels of the after-difficulty of recalling the memory of a deficiency that has been supplied. The paradox of to-day becomes the truism of to-morrow. And in spite of all her wonderful advancement in arts and manufactures, in spite of all her great names in every department of practical science, there is no country where both these phases of mind, apparently so inconsistent with each other, coexist more pertinaciously, more permanently, than in England.

The truth is that, opposed as they appear to be, they are the two sides of one and the same character, a character eminently and essentially practical, which cannot recognize anything but what is, and will consent to look neither into the future nor the past with a very patient gaze. We smile at the imaginative habit of mind of the German, and the precipitate quickness of the Frenchman; yet in fact, through sheer practical industry, we surpass in effective progress the dreams of the one, and the quick conceits and anticipations of the other.

But, inestimably valuable in result, this national character makes invention excessively difficult, except 
where it drops in as it were in the course of business, suggests itself to the mind of the workman, and in a workman-like way, to ease him in his task, or to shorten a process done for the thousandth time before the abbreviating link in the chain of practical cause and effect forced itself upon his notice. Anything like $\grave{a}$ prior investigation of a problem-elementary view of the principles lying at the root of a processis with us the rarest source of invention. Thus it is that a clever machine makes the workmen employed upon it intelligent; as the insect takes its colour from the leaf it feeds on. Discovery follows discovery in rapid succession; and each room in a cotton mill or manufactory, - we are informed as we pass through, -presents an accumulation of little additions and improvements, a hive of ingenuity as well as industry, all resulting, as it were, spontaneously from the suggestive influence upon the workman, of the machine that at once employs and instructs him. .

Not so in Agriculture! The educational effect of the Steam-engine upon those it employs, so strikingly visible in manufactures whose date is of yesterday, has here not begun its gracious operation. Here the new power has not yet come in to suggest new processes. The hind ploughs as his fathers ploughed, as 
the Roman ploughed, as the Egyptian ploughed: and with even less advantage: for in the dry soils and climates of Rome and Egypt the plough was an apter instrument of cultivation than in our damp soil under our northern sky.

True, a better machinery has found its way into the more intricate task of threshing out the grain, and from that it has still more recently crept, backwards, from the last operation of threshing the grain, to that of reaping it. For it is curious to notice, in passing, that it has begun at the latter end of the farmer's labour,-a significant token perhaps of its ultimate direction and success, in the earlier details of field-work. The Flail was the first to give way: and by the ingenuity of Menzies, the revolving drum of the Threshing-machine, beating out the grain by continuous circular motion, was substituted for the alternate strokes of the flail (just as in navigation, the circular Paddle took place of the back-andforward action of the Oar), whilst the horse-power was concentrated round a pivot, the nearest approach horse-power has made to what we commonly understand by the word Machinery. This point achieved, the introduction of the Steam-engine to that branch of farm operations was at once made easy. The right 
motion existed before the Steam-engine was brought to bear upon it.

Once let this be done for clay-soil cultivation; once let all that has been said and written, and proved, about the properties of such soil, and the properties of the atmosphere, the habits of plants and instincts of roots, condense into an act of mechanism whose aim and object shall be the most perfect subdivision that can be effected at a single operation; and the conquest of the clays is achieved. It will then be seen that none but a PORTABLE power could accomplish it, that its practicability lay hidden in the womb of the future, till the Steam-engine appeared, and manual and horse power were severally discarded, the one to the garden, the other to the road, where locomotion from place to place is a real and primary object of the power and mechanism employed.

The infinitely graduated varieties of soil that exist between the lightest sand and the stiffest clay, preventing as they have done that marked line of different treatment that a more rigid contrast of the opposed qualities of sand and clay would have suggested, - together with the further variations of 'temper' alternating with the conditions of wet and 
dry, - have been too much perverted to the result of making the agriculturist a Jack-of-all-trades. He goes out of a light-soil farm into a clay, or vice versâ, and plunges his share into the new element with about as much unconcern as his wife puts her duckeggs under a hen to be hatched and educated. Plump goes the little brood of changelings into the first pocl of water, incontinently bent on their baptism of native mud, to the consternation of the astounded mother, who vainly plies her claw in scratching on the sandy shore for unsuited food, croaking out her frantic warnings to the contumacious family of webfoot. With about as intelligent a philosophy as she exhibits under such distressfur and hopeless circumstances, has many a plough been stuck into the clays. But nothing can express the truth in shorter phrase than that of old Dobson-_

'I tell you, Sir, -it's a different trade!'

No wonder then that 'the best form of the Plough is still matter of disagreement.' It must ever be so, as long as Clay and Sand are things as opposed in nature to each other as positive and negative. A stiff clay under a moist climate, the greater its mechanical disadvantage, and its intrinsic chemical superiority, 
(and both are fully admitted), the more it seems to call for a revolution in its mode of culture,-for a system peculiar to itself. In the arts, as well as in morals, 'Difficulties are opportunities.'

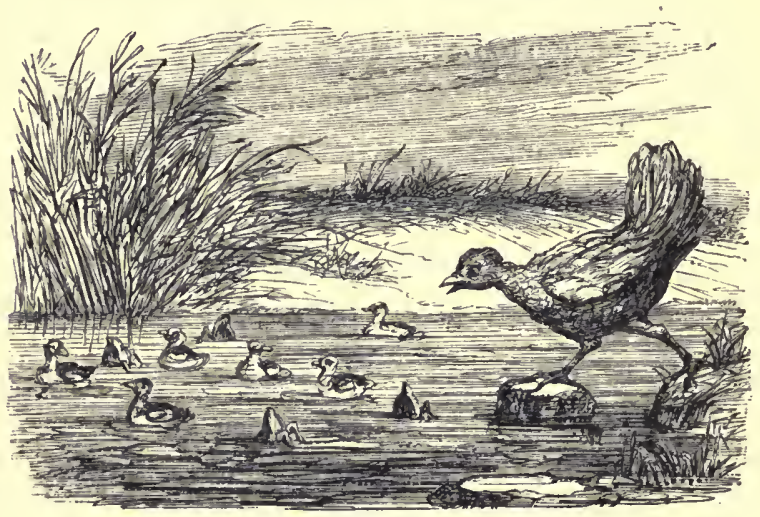

'Incontinently bent on therr baptism of native mud.' 


\section{XXIV.}

\section{CONCLUSION.}

DAY after day, month after month, year after year, the labour of the Husbandman begins afresh. It is without end, middle, or beginning. It defies the 'Unities' of Time and Action. And as its nature is, so must be its everlasting development, literary as well as otherwise. To give it a somewhat livelier tongue - to rescue it, at least for an occasional hour, from a tone and treatment which, under the boasted title of ' practical,' would scare away from its deeply interesting discussion all that has adorned as well as advanced so many other equally laborious and less naturally attractive pursuits, was the motive that suggested the too desultory chronicle of deeds, of words, of thoughts, that these pages have imperfectly recorded. A story without an end, a soliloquy without a speaker, a dialogue without a dénouement, and, what is worse than all, a ' Farm to let' without a Tenant! Such is the discursive and informal shape taken, as of 
its own accord, by a series of extracts from a journal extending over many years, of which it will be enough if he who reads shall haply say, he 'could have better spared a better' tale.

But though it break and baffle every rule of literary composition - though it leave every interest unsatisfied, every curiosity unquenched-let it not be deficient in the one intransgressible rule of Harmony - to end in the Key-note: and so doing, let it speak at least with one consistency, and leave upon the ear one simple and abiding chord that may link it with pleasant memories, and, if more and better yet than this may be hoped, may lighten and sustain the solitary hour of some future toiler, striving all alone, and far away from suitable converse and encouragement, to solve the tedious problem presented by a difficult soil, and, what is more difficult than that to cure or cope with, intractable opinions, and minds that no argument can reach, no evidence assure.

Bowed by an affliction, for which life contains no cure, and calendaring his remaining years of earthly solitude as a schoolboy marks off one by one the weary list of weeks that must intervene before the joyful hour that shall restore him to all he has lately parted from, the writer of these pages was fain to 
welcome the emprise of a task which might have scared away, as indeed it had done, all to whom life was not so dead, that the only thing that could rise again upon it was-a blister.

Such was in truth the condition under which, to the amazement of that surrounding world called 'Friends,' and the consternation of that critic's gallery, called Tenantry, I ventured on the solitary occupation of a farm whose desolate and repulsive features have been sufficiently portrayed, and with little of exaggeration. Steeped to the eyes in all those notions of science and exactness which a working University experiences, and ' those Temples twain, Inner and Middle,' may be supposed to infuse into the brains of younger sons, I plunged into my task with all that sanguine and pedantic enthusiasm best known, in farming, under the expressive title of ' Fire-edge.' ' A blessed thing,' I have before said, ' is the untaught boldness of youth!' a blessed thing in its way, and in its time and place. It is as much intended, and has its appointed task, in the great Order and Economy of things, as the most cautious sagacity and profound experience of advanced life. ' There is that scattereth and yet increaseth:' and He who appointed life as an advancing experience, 
appointed every part of it to accomplish, and to vindicate, its appropriate phase and character.

So I now feel it, whether I mentally review the enterprise, labour, and amusement of years gone by, or whether I look over the comparatively reclaimed acres and shrub-embosomed homestead of the once dreary spot it was my privilege to find 'thrown upon my hands' at a moment when the drearier waste within defied the outer landscape. Could the scene be presented to me again with the aspect it once wore, I should hardly, even with the bought economy of experience, have the boldness to attack it: but if compelled to do so by duty or necessity, the only difference in my course would be a more resolute and comprehensive plan, based upon a deeper reliance on my first instincts and judgment, unchilled by the timid and discouraging language which surrounding practice casts, in nearly every district, across the path of the improver in agriculture.

Whence this timidity and this discouragement?

With the attempt to answer this important question my task shall be concluded; and the personal experience of a landowner occupying the most difficult of his own farms, and striving to 'sound the bass string' of the matter, by assuming the actual circum- 
stance and position of those whose interests it was his duty to study and understand, shall be stated, with such reflection as most suggests itself to one who, while his spare shelves were filling with ' Agricultural journals,' and the works of Tull, Mills, Liebig, Johnston, and others ' of that ilk,' still kept an eye upon his Law-books.

The evil of retarded and discouraged investment in the soil lies deep, and dates far back. It is not the fault of the Farmer : he is the subject, the time-grown and created result of the Legislation, and Custom with the force of legislation, that have made him what he is, and invested him with a stepmother relation to the soil. By the Law of primogeniture applied to Land alone of all other kinds of property and capital, you have set on foot in this country a system which has nearly reached its climax in the amassing and aggregation of land into the hands of few and large owners. The ancient yeoman, the owner of his own farm, is becoming or become an extinct genus animalium. By the enormous and factitious costliness, delay, and difficulty attending the Transfer of land, increasing in an inverse ratio with the acreage (for the relative cost of 'title' to an acre is beyond all comparison greater than that of a hundred, and of a hundred in like man- 
ner to a thousand), you have secretly clenched and fortified the process which entail and primogeniture had openly avowed and established, and rendered it impossible, on the common principles of prudence or economy, for anyone to buy land (except for building) otherwise than in large and increasingly larger quantities. The tendency is not stationary; it is still going on. The man of small or moderate capital is becoming every day more and more effectually ousted from the possibility of ownership in ' the earth,' which 'was made for all.'

You point to France and Belgium, where there exists an opposite law compelling subdivision, with a still more evil tendency, if possible; and talk about 'political expediency,' and the mischief of ' morcellement.' But must we rush into one extreme to ariod the other? or is our timid intelligence so scared that it cannot pause to distinguish between a tyranny which enforces subdivision, and that middle course which would allow Land, like every other form of capital, to adapt itself naturally to human need and circumstance, and wholesomely to exist in great and small proportions? Or is our political philosophy of such a school as to allow the supposition that we have the MORAL RIGHT to 'capitalize' the earth, and disfran- 
chise seventy-nine eightieths of the inhabitants of this country by ' Act of Parliament,' and the 'Custom of Conveyancers?' - [ for it is authoratively saidand there are no statistics to disprove it! - that the owners of land do not number above two liundred and fifty thousand, out of a population of twenty millions !] Instead of the soil being, as it was meant to be, the first and best of Savings-banks for capitals of every size; to the Peasant and the Yeoman, as well as the Duke and the Squire; we assume the audacious office of readjusting natural and common rights, and pronounce for a system which agglomerates land into hands that may monopolize, but after all cannot themselves use it, and cut down the whole interest of the rest of the 'agricultural community' to the rank and position of 'Tenant-farmers.' They do not, as a class, penetrate the meaning or the mischief of it: they are 'to the manner born,' and think it ' all right' if they could only get ' Tenant-right ;' (as if the hirer of an article of limited supply, could have any 'right' but what the owner may choose to give him !)

But then a LEasE! What is the use of a Lease for the purpose of investment, unless it be of long duration? Nay, it is often urged against leases, that 
under a good landlord farms pass from father to son, and grandson, better without a lease than with one: then why not as property at once? Why keep up the form and farce of ' ownership,' if its very excellence consist in a virtual surrender of its exercise, except to receive the 'dividends' half-yearly, under the name of ' Rent,' and pay annually for the ' repair' of premises you never occupy?

Not that there are wanting many instances of improving Tenants and liberal Landlords. Thank Heaven, the worst laws are modified in practice by the common sense of mankind, as well as the best evaded by its ingenuity. It is the universal and unprofitable substitution of ' tenancy' for ownership that is here spoken of,-the territorial mapping of the country into dukeries and squiredoms, the impounding of the soil out of the action of free investment, and the compression of its inviting and unexplored capabilities within the complicate trammels of a fiction,- the fiction of an Owner that does not occupy, and an Occupier that does not own.

Why should this be? Why should Law, the instant it applies to Land, depart from its simplicity and even-handedness by making land, alone of all other forms of property and capital (that fall under 
its occasional operation by intestacy or disputed right), an exception to the general rule of fair and equitable division? In the freest of all free countries, where freedom is 'the law of the land,' why should not ' the land'itself be free? Why is it that so few will take the pains to understand the question enough to see that ' primogeniture' is a thing which families may make for themselves if they please, like heirlooms; but which the Law has no more to do with than with the descent of my Lady's Jewels to the next ' my Lady,' though under the Statute of Distribution of the effects of Intestates they would be treated as personalty, and divided accordingly.

Again and again be it understood, that it is not the compulsory division of land that is advocated; but simply the application to it of our own existing law applicable to every other form of capital, favouring neither its aggregation nor partition, but leaving it to assume its natural proportions and relation to the wants and habits of society, like any other article in which Industry invests its savings. Wrap yourself in the triple armour of Custom, Prejudice, or Feudalism, immoveable admirer of primogeniture-by-Law; but know that every great and accredited writer on national economics, from Adam 
Smith to John Stuart Mill, maintains the freedom of land from the feudal shackles of long entail and primogeniture-by-law, as the prime and fundamental rule of 'Justice to society' in the matter of the Soil. The change that we want is but little, but that little underlies and interpenetrates the whole economy of agriculture as a national business, and renders every acre uncultivated or half-cultivated through the operation of legal trammels upon the owner, a robbery upon the Labourer, the Capitalist, and ultimately on the public purse. It is the first and the most natural of Savings-banks to the humble, as well as of Investments to the wealthy capitalist. It is endowed with the most natural and versatile aptitude to the capabilities of both; it belongs to the Spade as well as the Plough. It is evident as an instinct to every mind, and needs neither proof nor argument, that the soil is the 'primest, eldest' investment of our capital : to risk our national earnings and accumulations in any other channel till this field is first exhausted, is a course that men may indeed be driven to by the operation of foolish laws or customs, but which few, from either will or circumstance, would voluntarily choose. It needed no small ingenuity of folly, no small ' method in our madness,' to produce 
that timidity and reluctance of investment in the soil which the disposable capital of this rich country exhibits. It is almost vain to argue against a feeling. Once make the cultivators of the soil feel, as a body, that in the Land itself they have really no interest beyondits annual produce, and you poison agriculture at its source. Shallow draining, shallow cultivation, shallow reckonings, and shallow knowledge of his business, are not naturally inherent in a man because he is a 'Tenant-farmer;' but in a country where the law (as happily with us) reigns supreme, an erroneous law applied to the land may by degrees really make it come to appear so. And this has been the case with us : first, by the incessant recurrence of law expenses which our system involves, pressing with every form of costliness upon the soil, saddling every landed estate, in addition to the owner, the clergyman, the tenant, the labourer, and the poor, with the maintenance of its Lawyer,-- and secondly, by denying that last resource of inherited penury and embarrassed ownership, a free, speedy, and inexpensive mode of Transfer. The periodical ransacking which the musty muniments of an interminable 'Title' undergo to enable a few acres of land to change hands; to say nothing of those momentous occasions, death and 
marriage, or the complete revision of the whole matter whenever a mortgage is required,-form altogether a tribute of such oppressive magnitude, that Protection for the land from foreign competition is a dream indeed, compared to the reality of the muchdesired Protection from 'Law.' To fully develope and expose the extent to which our antiquated system of Tenures, our long Entails strung with disconnected life-interests, our conflicting institution of 'legal' and ' equitable' estates, our prolix conveyances, and complicated settlements, operate as a charge upon the land, an impediment to its exchange, a reduction of its value, a drain upon the resources of the Owner, a secret injury to the Tenant and the Labourer-would be to write the heaviest satire upon the struggle for Protection that has ever yet been showered upon a class powerful to achieve, if they ouly willed it, the completest satisfaction for the repeal of the Corn-laws which an important body could command or an intelligent community approve. Do what you will for land, this lies at the bottom of, and completely surpasses in importance, all other 'Improvements.' Free the soil from the pestilent tyranny of parchment, that the obsolete necessities and forms of centuries have gathered around it, 
and more will be accomplished for its increase in commercial value, its preference as a field for investment, its promotion of skill and invention, its contribution to the employment and the happiness of the greatest number, than all the mere physical improvements that could be enumerated or detailed, were every 'Clay Farm' in merry England to supply its 'Chronicle.'

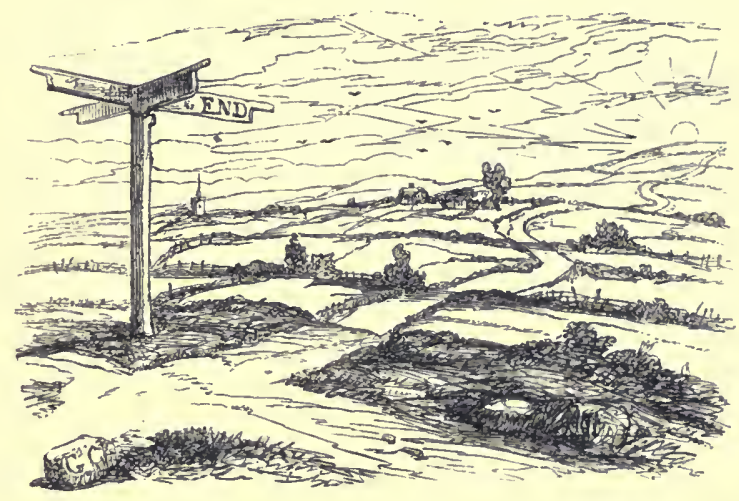



Sixth Edition, price 5s. $6 d$.

\section{T A L P A :}

OR

\section{THE CHRONICLES OF A CLAY FARM.}

With Twenty-four Mllustrations by George CrUIrshant.

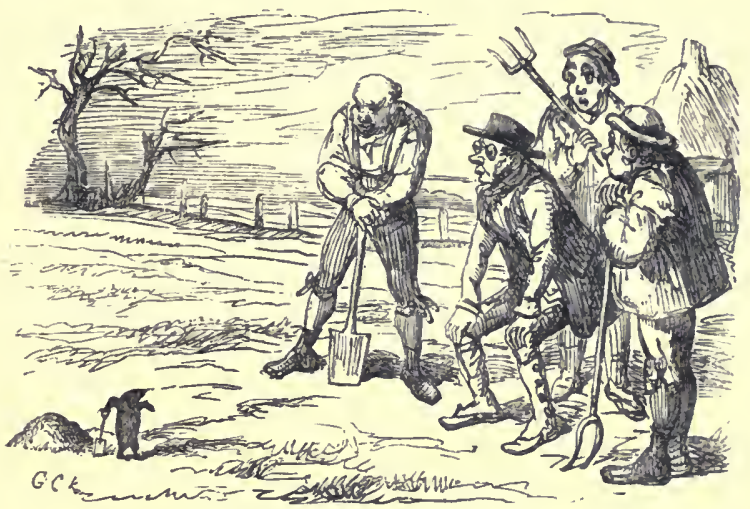

'We shall learn of him another, and a greater lesson, some day.'

\section{BY C. W. H.}

\section{Opinions of the Press.}

'The book ls as amusing as a novel,'-ATHRN aUM.

'The work will be read with interest aud advantage by every class of agriculturists - from the scientific experimentalist to the most obstinato stickler for primltive usages, who couducts the operations of husbandry in the system adopted by his greatgrandfather.'

NoRFOLK NEWs.

'C. W. H. is a maglcian at whose touch the hardest and most impractlcable clods mellow down into the kindest and most friable of soils. No wonder that the same magical wand should have power to transmute $\mathrm{a}$ theme so barren and repulslve as a Clay Farm into one fraught with amusemeut and mental gratification."

FABMERS' HEBALD.

'To find so much practical truth, conveyed with such brilliancy of fancy and literary power, is somewhat nnusual in agricultural literature, but we have scarcely ever seen a more successful illustration of the author's motto from Horace of telling the truth in a laughing way. . . . It will soon attain, as it deserves, a very high degree of popularity." 


\section{Talpa, by C. Wren Hoskyns.}

-This is a rare little volume. We don't know which to admire most, the author's humour or his wisdom. He has set himself the task of illustrating, in an agreeable manner, the Evils of Cnstom, Prejudice, and Feudalism, as they exist among agriculturists. It will create much laughter among the merry, and convey many a lesson to the tiller of the soil. There are some very capital illustrations, too, embellishing the volume."

ERA.

- The writer handles his subject in such a masterly manner-his style is 80 piquant, as well as forcible; so scholarly, yet so racy-his wit and his wisdom are so skilfully blended - he has so cleverly worked out his motto, Ridentem dicere verum, by telling the truth laughingly - that the reader finds himself irresistibly carried along, and he and the book part not company until he has made himself master of the tale that he lias to unfold.

LBICESTBRSHIRE MRRCURY.

- The author of Talpa has elicited humonr, wisdom, and we had almost said romance, out of a clay farm. In what superficially appears the most unpromising and unfertile of themes, he has found materials for a volume of such interesting and sug. gestive matter as has seldom been written about agriculture. The general reader will find mnch useful information from Ths Chronicles of a Clay Farm, which combines, with all the interest of a moderu novel, practical lessons of the first importance."

HERTFORD MIBRCURY.

- Onr agricultural readers will no doubt be surprised to learn that the sonndest lessons in agricultnral science, and yet one of the most amnsing books ever published, will be found with the above title; bat it is nevertheless true. truth when we say that Cruikshank has illustrated this work in his best style, yet the illustrations are hardly so humorous as the letter-press. Pleasantry, when in good taste, is an admirable set-off to a dull subject; but when it is accompanied, as in Talpa, with new and startling specnlations, which are so clearly defined, and bear so strong an appearance of truth, that they captivate every reader, we must con fess that a good work has been accomplished.'

LIVBRPOOL STANDARD.

\section{By the same Author.}

\section{In Uctober 1865 will be published, \\ OCCASIONAL ESSAYS.}

Contexts.

The Invisible World, or the Occult Powers of Creation.

The Domain of Physical Inquiry : an Address to the Warwickshire Natural History Society.

On Agriculture, its Rise and Progress in Great Britain.

The English Landowner.

The Battle Line of History, or the Influence of Battles on Human Progress.

London: LONGMANS, GREEN, and CO. Paternoster Row. 


\section{.}

, 


\section{UNIVERSITY OF CALIFORNIA LIBRARY}

\section{Los Angeles}

This book is DUE on the last date stamped below. 
S521 Hoskyns -

H79t Talpa

1865

S521

H79t

1865

UC SOUTHERN REGIONAL LIBRARY FACIITY

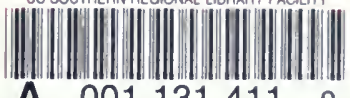

A 0011314119 
